\title{
BIOCHEMICAL AND CELL BIOLOGICAL ANALYSIS OF THE MECHANISM OF RNA INTERFERENCE IN HUMAN CELLS
}

\author{
Dissertation \\ zur Erlangung des Doktorgrades \\ der Mathematisch-Naturwissenschaftlichen Fakultäten \\ der Georg-August-Universität zu Göttingen
}

vorgelegt von

Agnieszka Patkaniowska

aus Kraków, Polen

Göttingen 2005 
D 7

Referent: $\quad$ Prof. Dr. Kurt von Figura

Korreferent: Prof. Dr. Ralf Ficner

Tag der mündlichen Prüfung: 18. Januar 2006 


\section{ACKNOWLEDGEMENTS}

I would like to thank my supervisor, Professor Dr. Thomas Tuschl, for giving me the opportunity to study the fascinating world of small RNAs in the fascinating city of New York;

Members of my thesis committee, Professors Dr. Kurt von Figura and Dr. Ralf Ficner, for their advice and support;

The Molecular Biology Program of the Georg-August-Universität and the International Max Planck Research School, for inviting me to study in Göttingen;

Members of the TT lab, former and present, for their help and the time spent together; My Friends in Poland, Germany and the US, for their continuous encouragement; My Parents, for patience, trust and love.

Thank you. 


\section{TABLE OF CONTENTS}

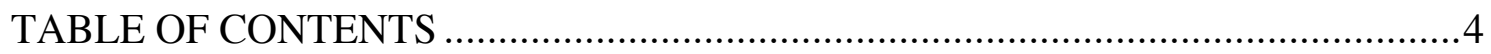

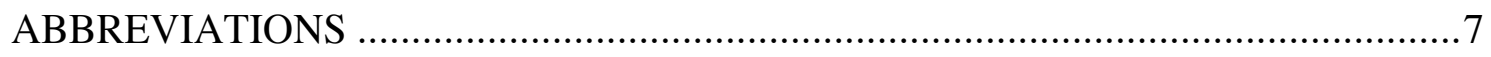

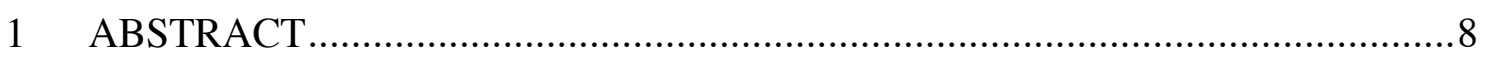

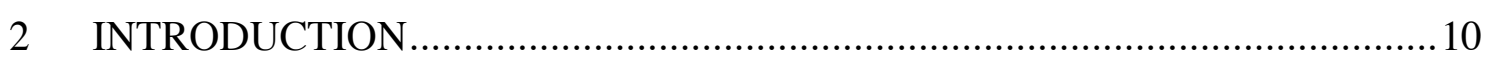

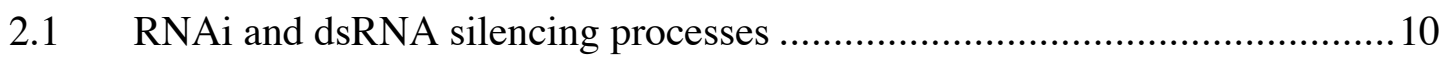

2.2 Discovery of dsRNA silencing processes ............................................ 12

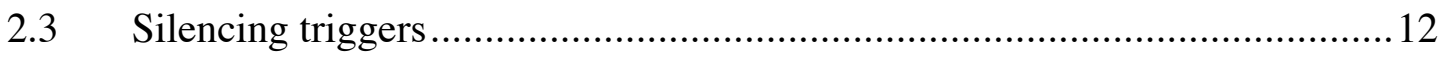

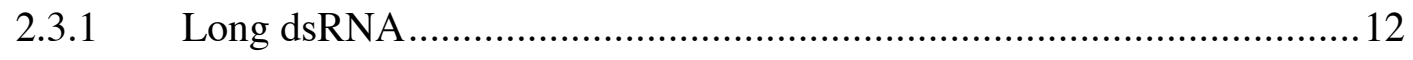

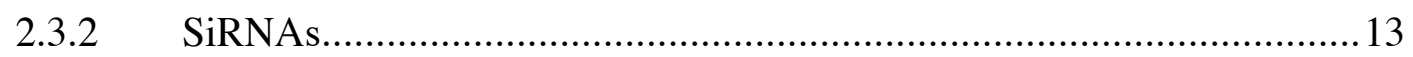

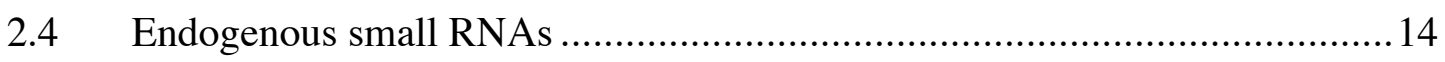

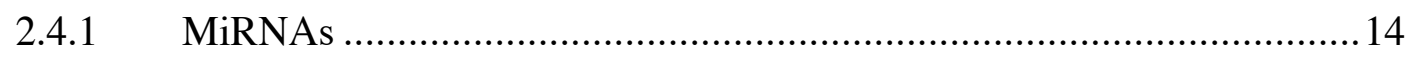

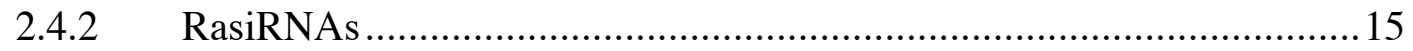

2.5 Proteins involved in dsRNA silencing ................................................... 16

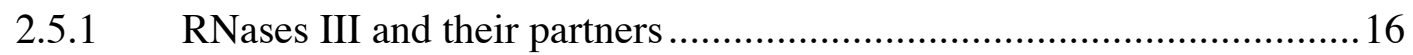

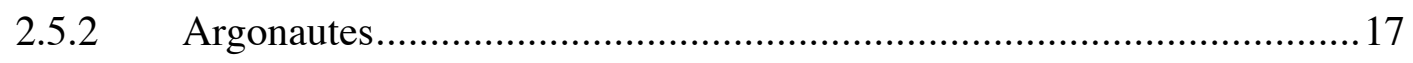

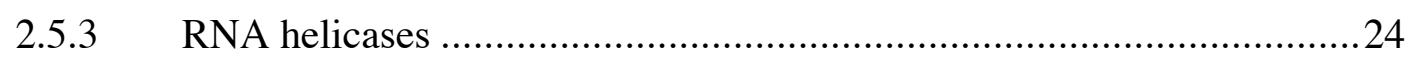

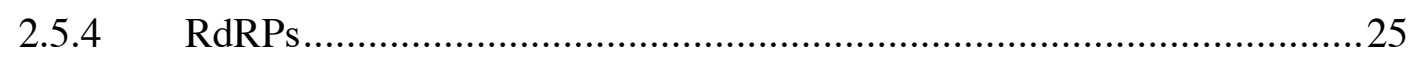

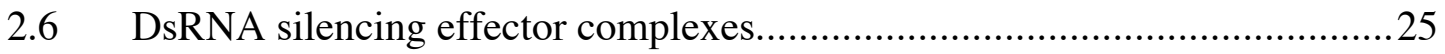

2.6.1 Assembly of catalytically active RISC ….........................................25

2.6.2 Target RNA cleavage by RISC.....................................................26

2.6.3 Composition of the RITS complex ................................................27

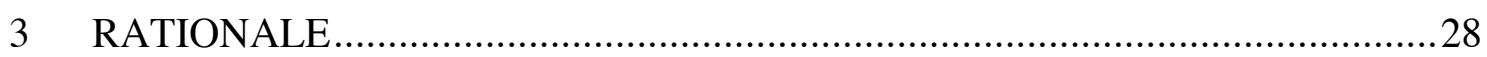




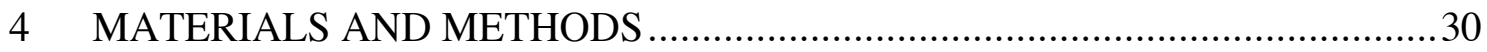

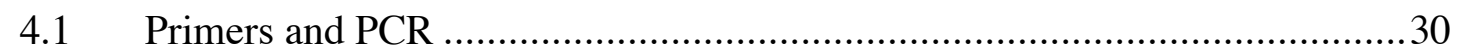

4.1.1 Quantitative real-time RT-PCR (qRT-PCR) ................................... 30

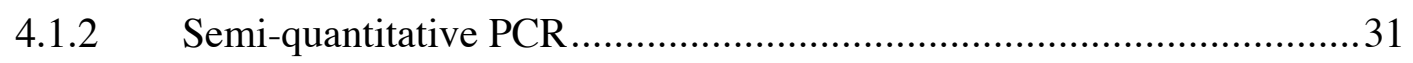

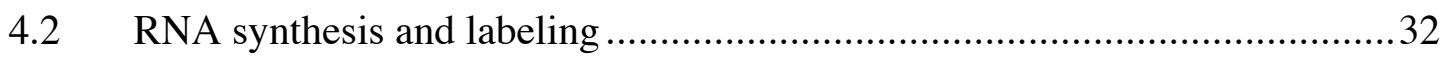

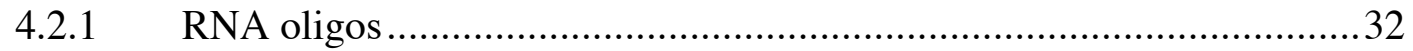

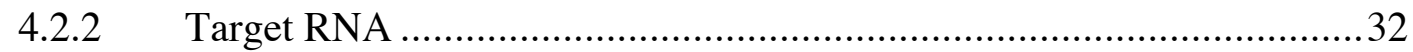

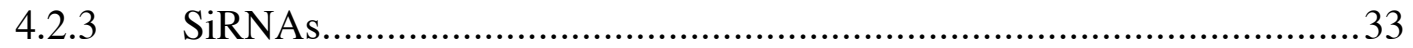

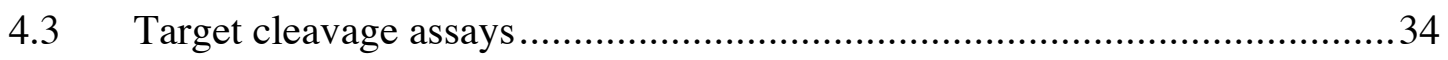

4.3.1 HeLa S100 extract-based target cleavage assay ................................34

4.3.2 Anti-FLAG bead-based target cleavage assay...................................34

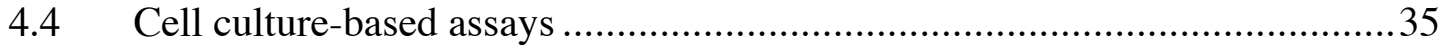

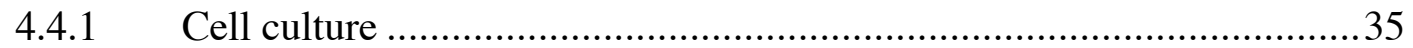

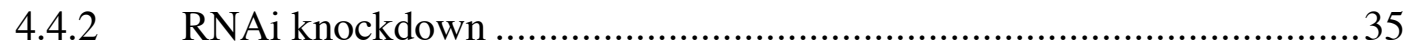

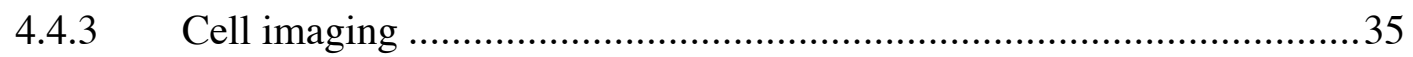

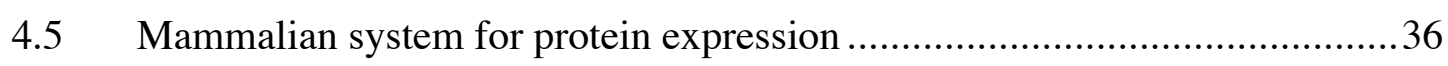

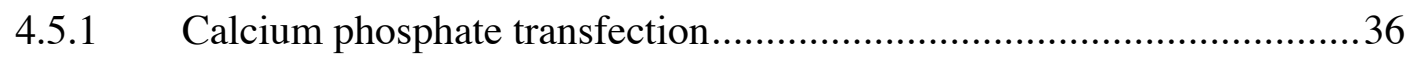

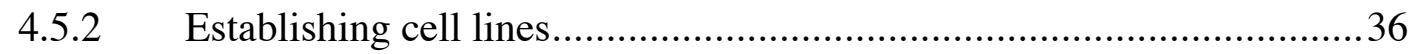

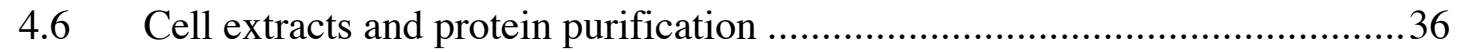

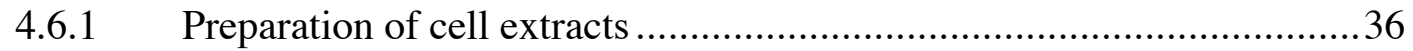

4.6.2 Anti-FLAG immunoprecipitation (IP) ............................................. 37

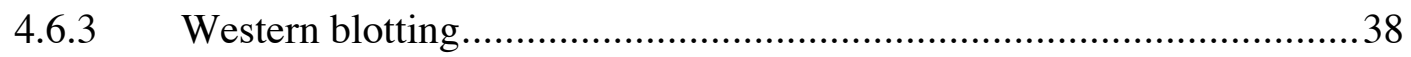

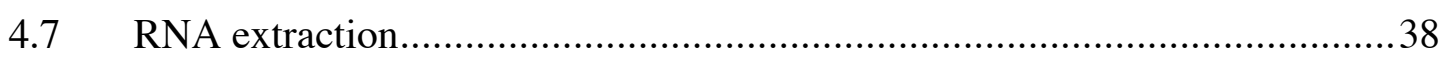

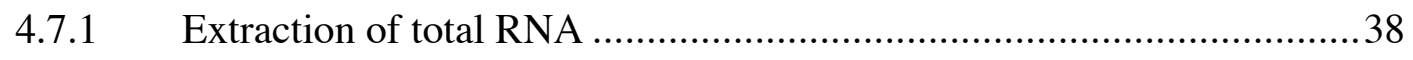

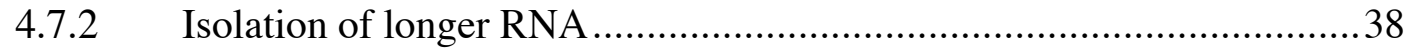

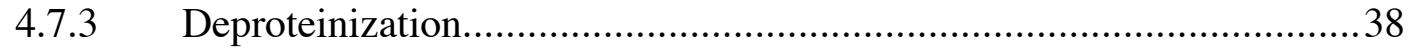

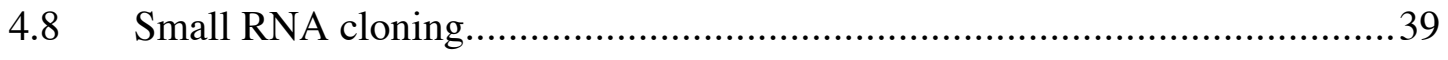

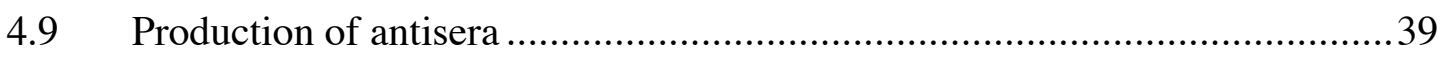


5.1 Fate of single- and double-stranded siRNAs in human cell extract and cultured cells

5.1.1 SiRNA duplexes in the HeLa S100 extract are stable and bear 5' P and 3' $\mathrm{OH}$ termini .40

5.1.2 Single-stranded siRNAs mediate RNAi in human cells 46

5.2 Characterization of the human Argonaute proteins 49

5.2.1 Human genome encodes 8 Argonaute proteins 49

5.2.2 The Agos are expressed in many cell lines .53

5.3 The Agos associate with miRNAs indiscriminately of their sequence............57

5.4 Characterization of the human Piwi subfamily .........................................61

5.4.1 Hiwi3 is expressed in human testis in a few splice variants ................61

5.4.2 Piwi members-specific antisera detect recombinant proteins .63

5.4.3 Piwi proteins do not guide target RNA cleavage in the standard reaction conditions. 64

6.1 Single- vs. double-stranded RNA trigger of RNAi

6.1.1 5' phosphates are maintained on an siRNA duplex ...........................67

6.1.2 Synthetic siRNAs undergoes ligation but not extension......................68

6.1.3 Single-stranded siRNA mediates RNAi in human cell culture .............69

6.2 Characterization of the human Argonaute protein family .70

6.2.1 The Agos are ubiquitously expressed and associate with miRNAs

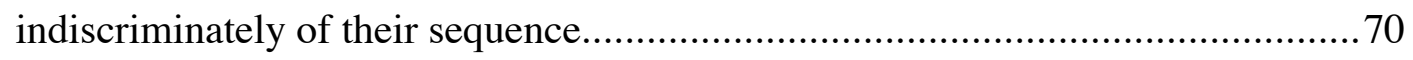

6.2.2 Expression of the Piwis may be largely germline specific....................70

6.2.3 Piwis are not catalytically active ...................................................... 71

6.3 Advances in the mechanism of RNAi in human ...................................... 72

6.3.1 Posttranscriptional gene silencing by RNAi.....................................72

6.3.2 Transcriptional gene silencing by RNAi .........................................73

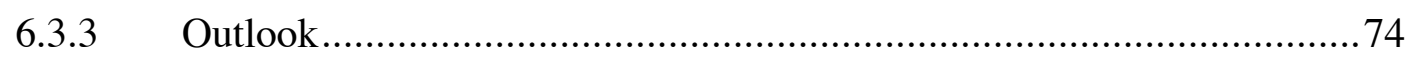

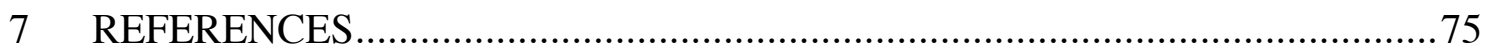

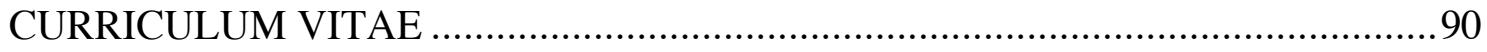

PUBLICATIONS AND PRESENTATIONS ............................................................ 91 


\section{ABBREVIATIONS}

$\begin{array}{ll}\text { as } & \text { antisense } \\ \text { bp } & \text { base-pair } \\ \text { dsRBD } & \text { dsRNA-binding domain } \\ \text { dsRNA } & \text { double-stranded RNA } \\ \text { GSC } & \text { germinal stem cell } \\ \text { IP } & \text { immunoprecipitation } \\ \text { miRNA } & \text { microRNA } \\ \text { miRNP } & \text { miRNA-containing RNP } \\ \text { nt } & \text { nucleotide } \\ \text { ORF } & \text { open reading frame } \\ \text { PCR } & \text { polymerase chain reaction } \\ \text { PGC } & \text { primordial germ cell } \\ \text { PTGS } & \text { posttranscriptional gene silencing } \\ \text { qRT-PCR } & \text { quantitative real-time RT-PCR } \\ \text { rasiRNA } & \text { repeat-associated siRNA } \\ \text { RdRP } & \text { RNA-dependent RNA polymerase } \\ \text { RISC } & \text { RNA-induced silencing complex } \\ \text { RITS } & \text { RNA-induced initiation of transcriptional gene silencing } \\ \text { RNAi } & \text { RNA interference } \\ \text { RNP } & \text { ribonucleoprotein } \\ \text { RT-PCR } & \text { reverse transcription PCR } \\ \text { s } & \text { sense } \\ \text { shRNA } & \text { short hairpin RNA } \\ \text { siRNA } & \text { short interfering RNA } \\ \text { TGS } & \text { transcriptional gene silencing } \\ \text { UTR } & \text { untranslated region } \\ & \end{array}$




\section{ABSTRACT}

RNA interference (RNAi) in human cells is efficiently triggered by short interfering RNA (siRNA) duplexes of 19-24 base-pairs (bp), which mimic the doublestranded processing intermediates of the endogenous small RNA species, microRNAs (miRNAs). Single-stranded siRNAs and miRNAs are incorporated into Argonaute protein-based RNA silencing complexes, to mediate inactivation of complementary mRNAs by cleavage or translational repression. There are eight Argonaute proteins expressed in humans, four Ago and four Piwi subfamily members, however only one of the Ago proteins is capable of the small RNA-guided cleavage of target mRNA. While all Agos can repress mRNA translation, the precise mechanism of this regulation is unknown. The role of mammalian Piwi proteins in RNA silencing processes has not been addressed. MiRNAs are predicted to regulate expression of one-third of the human genes. In light of the growing biological significance of RNA silencing processes, the current study addressed the mechanism of RNAi in human, focusing on two key components of RNA silencing complexes, small RNAs and the Argonaute proteins.

To examine the fate of small RNAs in human cell lysate recapitulating target RNA cleavage activity, stability and processing of the radioactively labeled single- and double-stranded small RNAs was monitored in time-course experiments. The RNA duplexes were stable in the extract and their termini were converted to 5' phosphate and 3' hydroxyl groups, similar to the endogenous small RNA intermediates. Singlestranded siRNAs were rapidly degraded. The efficacy of 5'-phosphorylated single- and double-stranded siRNAs was tested in the cell culture. The single-stranded siRNAs were sufficient to trigger RNAi in the cultured cells. This suggests, that although siRNA duplexes are the preferred triggers of RNAi, single-stranded siRNAs can bypass the regular assembly pathway of the RNA silencing complex, especially while being 5'phosphorylated.

To examine the expression pattern of Argonautes in human cell lines, levels of the individual transcripts were quantified by qRT-PCR. Agos were found expressed in multiple human cell lines, while Piwis were detected only in the control samples from testis and ovary tissue. To understand the functional differences between the four Ago proteins, the association of Agos with the endogenous miRNAs was examined. The 
results suggest, that miRNAs are incorporated indiscriminately of their sequence into the different Ago-containing silencing complexes. The restricted expression of Piwis is in agreement with the reports on their germline expression in mouse, and implicates involvement of the RNA silencing in germline-specific processes in human. To check if the Piwis are capable of siRNA-guided target cleavage, the tagged Piwi proteins were ectopically expressed and purified. None of the Piwis was catalytically active in the tested conditions. To allow investigation of the role of Piwi proteins in the testis tissue, individual Piwi-specific antibodies were raised and/or characterized. 


\section{INTRODUCTION}

\subsection{RNAi and dsRNA silencing processes}

RNAi is a cytoplasmic process in which double-stranded RNA (dsRNA) molecules trigger destruction of cognate mRNA transcripts. DsRNA is processed into 19-24 bp long RNA fragments, referred to as siRNA duplexes. One of the siRNA strands from the duplex is incorporated into an RNA-induced silencing complex (RISC) that guides it to a target mRNA. RISC cleaves mRNA complementary to the sequence of the siRNA it carries (reviewed by (Tomari and Zamore, 2005b)).

RNAi belongs to an evolutionarily conserved group of dsRNA silencing processes (Fig. 1), which are mediated by small RNAs, such as miRNAs and repeatassociated RNAs (rasiRNAs). Small RNAs derive from long dsRNA or hairpinprecursors (pre-miRNA) processed by Dicer, an RNase III-type enzyme. Dicer, together with its interacting partner TRBP, forms a RISC loading complex (RLC). RLC incorporates only one strand of the RNA duplex into an effector complex, which contains an Argonaute protein family member. The other strand of RNA duplex is cleaved (if perfectly complementary and associated with Ago2 Argonaute) or unwound by a helicase (reviewed by (Preall and Sontheimer, 2005)). Small RNAs guide effector complexes to the target RNA transcripts on the basis of sequence complementarity. Complexes containing siRNAs (RISC) and miRNAs (miRNA-containing ribonucleoprotein, miRNP), target cytoplasmic mRNA transcripts for inactivation through either degradation or translational repression (post-transcriptional gene silencing, PTGS). Complex containing rasiRNAs (RNA-induced initiation of transcriptional gene silencing complex, RITS), acts in the nucleus at the transcriptional level (transcriptional gene silencing, TGS). RITS complex is proposed to target nascent transcripts from the silenced loci (reviewed by (Martienssen et al., 2005; Verdel and Moazed, 2005)). 


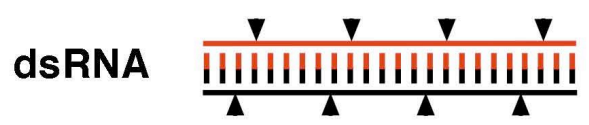

TIIIIIII pre-miRNA
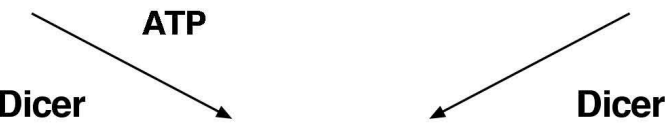

SIRNA or rasiRNA duplex

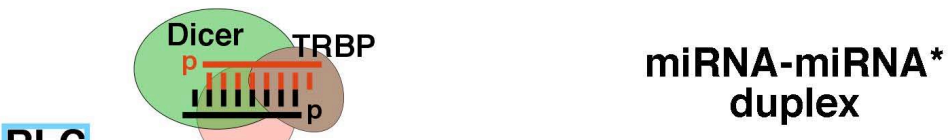

RLC
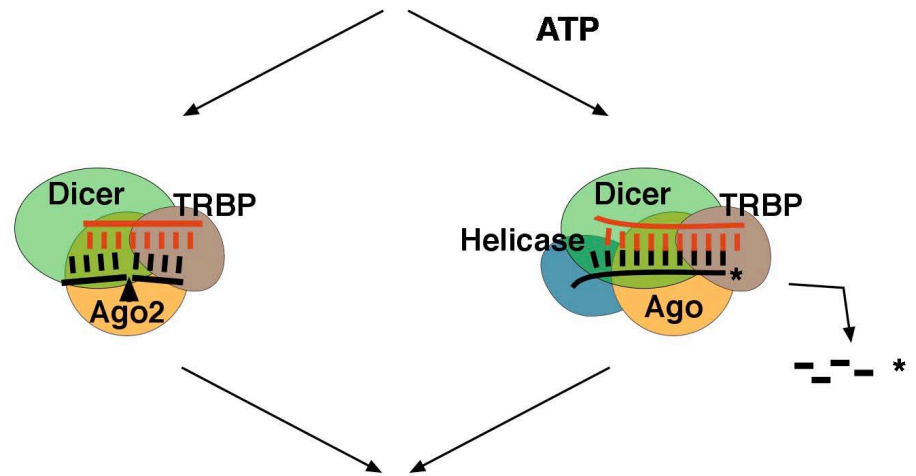

effector complex RISC/miRNP/RITS

\section{Ago}

IIIIIIII

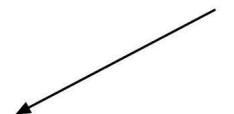

$\downarrow$

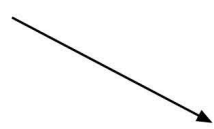

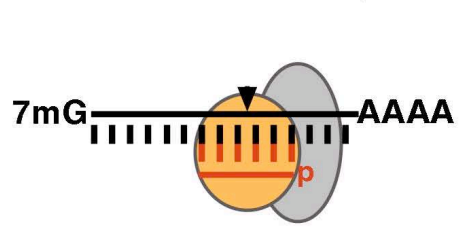

mRNA cleavage

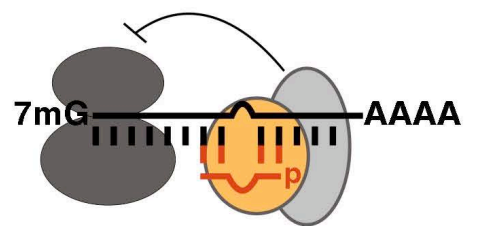

translational repression

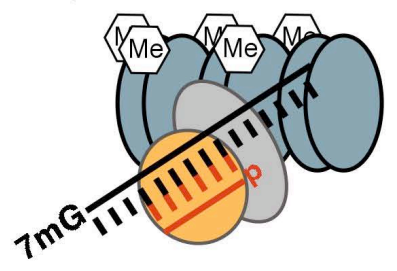

chromatin modification

Fig. 1 RNAi and dsRNA silencing processes. Description in the text. 


\subsection{Discovery of dsRNA silencing processes}

RNA silencing was first observed in plants, in which introduction of transgenic copies of an endogenous gene resulted in 'coordinate suppression' of all copies of that gene, including the endogenous one (Napoli et al., 1990; van der Krol et al., 1990). This so-called 'co-suppression', in some cases was due to a cytoplasmic process leading to the reduced transcript levels as a result of PTGS (Napoli et al., 1990; van der Krol et al., 1990). In other cases, co-suppression was attributed to a nuclear process leading to DNA methylation resulting in TGS (Assaad et al., 1993; Matzke et al., 1994). It was observed, that transcription of transgene arrays might result in accumulation of dsRNA transcripts, similar to those produced during the viral replication.

Transgene-induced gene silencing was independently described in a filamentous fungus Neurospora crassa, where it was dubbed 'quelling' (Pandit and Russo, 1992; Romano and Macino, 1992).

In parallel, a technique was developed to down-regulate gene expression in Caenorhabditis elegans, by expressing gene-specific antisense transgenes (Fire et al., 1991). This was meant to 'interfere with a late step in gene expression' and led to the discovery of dsRNA as a trigger of RNAi (Fire et al., 1998).

Thus, the seemingly unrelated phenomena of co-suppression, quelling and RNAi emerged as different aspects of an ancient defense mechanism against dsRNA, which may appear in the cells during viral infection and mobilization of genomic repetitive elements.

\subsection{Silencing triggers}

\subsubsection{Long dsRNA}

In the first RNAi experiments, Andrew Fire and colleagues demonstrated, that introduction of 300-1000 bp dsRNA to the worm results in a specific reduction of the cognate mRNA and its protein product, causing specific phenotypical changes in the affected animals (Fire et al., 1998; Montgomery et al., 1998). Since dsRNA targeting promoter and intron sequences did not trigger gene silencing, RNAi was concluded to act posttranscriptionally, in the cytoplasm (Fire et al., 1998; Ngo et al., 1998). Efficient 
and specific gene silencing induced by dsRNA was subsequently reported also in trypanosoma (Ngo et al., 1998), fly embryos (Kennerdell and Carthew, 1998) and plants (Waterhouse et al., 1998). Degradation of mRNA triggered by dsRNA was recapitulated in a cell-free system based on Drosophila melanogaster embryo lysate (Tuschl et al., 1999).

RNAi by long dsRNA found application as a tool for gene knockdown in a range of animal systems, including planaria (Sánchez-Alvarado and Newmark, 1999), hydra (Lohmann et al., 1999), frog (Nakano et al., 2000) and in murine oocytes, embryos, embryonic stem cells and embryonal carcinoma cell lines (Wianny and Zernicka-Goetz, 2000; Billy et al., 2001; Yang et al., 2001). In the majority of mammalian cells, however, dsRNA longer than $30 \mathrm{bp}$ binds to and activates protein kinase PKR and 2',5'-oligoadenylate synthetase (2',5'-OAS), both of which trigger the interferon response (Stark et al., 1998).

\subsubsection{SiRNAs}

In 1999, David Baulcombe's group discovered that 25 nucleotide (nt) RNA species accumulated in plants undergoing transgene- and virus-induced gene silencing processes. The small RNAs matched the silenced sequences in both sense and antisense orientation (Hamilton and Baulcombe, 1999). Accumulation of the 21-25 nt RNA fragments cognate to the long dsRNA was also observed during the RNAi process in S2 cells (Hammond et al., 2000), fly embryo (Yang et al., 2000), fly embryonic extract (Zamore et al., 2000), and in worm (Parrish et al., 2000).

The short RNAs were demonstrated to be cleavage products of both strands of the long dsRNA (Zamore et al., 2000). This suggested involvement of a dsRNAspecific RNase III-like endonucleolytic activity in long dsRNA processing (Bass, 2000). Among the RNase III family enzymes of D. melanogaster, Dicer (Dcr-2) was found to cleave the long dsRNA into small RNAs (Bernstein et al., 2001; Liu et al., 2003; Lee et al., 2004b).

The short RNAs were characterized as RNA oligonucleotides of $\sim 21 \mathrm{nt}$ forming duplexes of $\sim 19$ bp with 2 nt 3'-overhanging ends, bearing 5' phosphate and 3' hydroxyl groups at the termini (Elbashir et al., 2001b). Short dsRNAs were named siRNA duplexes after they were chemically synthesized and demonstrated to guide the cognate mRNA cleavage in the process of RNAi (Elbashir et al., 2001b). A single 
siRNA strand of the duplex was demonstrated to be sufficient to target mRNA degradation (Martinez et al., 2002; Schwarz et al., 2002). This strand was called the 'guide strand', while the other was dubbed the 'passenger strand'.

Soon after the discovery, siRNAs were shown to be able to induce RNAi in mammalian cell culture (Caplen et al., 2001; Elbashir et al., 2001a). Since siRNAs are too short to induce the interferon response, they became a major breakthrough in reverse-genetics experiments allowing researchers to significantly reduce level of the protein of their interest from a whole variety of experimental systems (Dorsett and Tuschl, 2004).

\subsection{Endogenous small RNAs}

There are two well-characterized classes of small RNAs mediating RNA silencing processes, miRNAs and rasiRNAs (reviewed by (Kim, 2005)).

\subsubsection{MiRNAs}

The first two miRNAs, lin-4 and let-7, were found in genetic screens to regulate developmental timing of $C$. elegans (Lee et al., 1993; Reinhart et al., 2000). Both of these 21-22 nt long RNAs derived from imperfectly base-paired stems of $\sim 70 \mathrm{nt}$ long stem-loop precursors (pre-miRNAs) (compare below) (Lee et al., 1993). MiRNAs were considered a worm-specific peculiarity, until the gene encoding let-7 was found to be highly conserved across bilaterian phylogeny (Pasquinelli et al., 2000).

Novel miRNA sequences were discovered serendipitously in D. melanogaster extract. They were cloned together with siRNAs derived from long dsRNA in the process of RNAi (Elbashir et al., 2001b; Lagos-Quintana et al., 2001). The systematical identification of endogenous small RNAs in various animal species commenced (LagosQuintana et al., 2001; Lau et al., 2001; Lee and Ambros, 2001). Until now, hundreds of unique miRNAs have been identified (http://microrna.sanger.ac.uk) and many of them are evolutionarily conserved.

The mechanism of miRNA action is to suppress expression of a set of target genes, by annealing to the imperfectly complementary sequences in the 3' UTRs of their mRNA (Lee et al., 1993; Wightman et al., 1993), and/or to eliminate target mRNAs by directing their cleavage (Llave et al., 2002b; Yekta et al., 2004; Bagga et al., 2005). The mode of miRNA action is believed to depend on the degree of 
complementarity between miRNA and its target (Hutvagner and Zamore, 2002; Doench et al., 2003; Zeng et al., 2003) and/or on the Argonaute protein present in the effector complex (Liu et al., 2004; Meister et al., 2004).

Most miRNA genes are transcribed by RNA polymerase II to generate long primary transcripts (pri-miRNAs) (Cai et al., 2004; Lee et al., 2004a). Pri-miRNAs are first trimmed to release the hairpin intermediates, pre-miRNAs (Lee et al., 2002). This cleavage is executed in the nucleus by RNase III-type enzyme Drosha (Lee et al., 2003). Drosha forms a large 'microprocessor complex', which includes Drosha's essential cofactor DGCR8/Pasha, a protein containing two dsRNA-binding domains (Denli et al., 2004; Gregory et al., 2004; Han et al., 2004; Landthaler et al., 2004). Pre-miRNAs are transferred to the cytoplasm by Exportin-5, which is a member of the Ran-dependent nuclear transport receptor family (Yi et al., 2003; Bohnsack et al., 2004; Lund et al., 2004). Upon arrival in the cytoplasm, pre-miRNAs are subjected to processing by Dicer (Grishok et al., 2001; Hutvagner et al., 2001; Ketting et al., 2001). Dicer cleaves premiRNAs into the short-lived miRNA duplexes, which are often thermodynamically asymmetrical - one end of the duplex is stronger base-paired than the other. The strand with the less stably base-paired 5' end becomes the mature miRNA, while the other strand ( $\left.\mathrm{miR}^{*}\right)$ is, in most cases, degraded. This is reflected in the natural occurrence of miRNAs derived from one strand of the pre-miRNA hairpin precursor, rather than from the other (Khvorova et al., 2003; Schwarz et al., 2003).

The hairpin structure of pre-miRNAs is often imitated and applied as an RNAi tool known as 'short hairpin RNA' (shRNA) (Tuschl, 2002; Siolas et al., 2005). The discovery of asymmetry in small dsRNA processing, which appeared to be true also for multiple siRNA duplexes, dictates the rules for design of efficient and specific siRNAs (Mittal, 2004).

\subsubsection{RasiRNAs}

RasiRNAs were discovered in the process of cloning of siRNAs derived from long dsRNA during RNAi (Djikeng et al., 2001; Elbashir et al., 2001b; Hamilton et al., 2002; Llave et al., 2002a; Reinhart and Bartel, 2002). These 21-28 nt RNA species were named repeat-associated siRNAs (rasiRNAs), as they match repetitive genomic sequence elements in both sense and antisense orientation.

RasiRNAs are presumed to derive from the long dsRNA formed by transcription 
of both DNA strands and/or by the action of RdRP on the nascent RNA transcript (Motamedi et al., 2004). In both cases, involvement of RNA polymerase II in the transcription was suggested (Cam et al., 2005; Kato et al., 2005). Subsequently, long dsRNA is processed by Dicer yielding rasiRNAs (Lee et al., 2004b; Pham et al., 2004; Xie et al., 2004). RasiRNAs are proposed to guide RITS complex to nascent transcripts from the silenced loci. They play a role in the establishment of heterochromatin in repetitive elements, leading to their transcriptional silencing (reviewed by (Martienssen et al., 2005; Verdel and Moazed, 2005)).

RasiRNAs were found in Trypanosoma brucei (Djikeng et al., 2001), Schizosaccharomyces pombe (Hall et al., 2002; Reinhart and Bartel, 2002; Volpe et al., 2002; Noma et al., 2004), D. melanogaster (Aravin et al., 2001; Pal-Bhadra et al., 2002; Aravin et al., 2003), C. elegans (Sijen and Plasterk, 2003), Danio rerio (Chen et al., 2005) and plants (Hamilton et al., 2002; Llave et al., 2002a; Mette et al., 2002; Xie et al., 2004).

\subsection{Proteins involved in dsRNA silencing}

Genes encoding the key proteins in the silencing processes were initially discovered in screens conducted to identify genes responsible for quelling in N. crassa (Cogoni and Macino, 1997), co-suppression in Arabidopsis thaliana (Elmayan et al., 1998) and RNAi in C. elegans (Tabara et al., 1999).

\subsubsection{RNases III and their partners}

Members of the RNase III protein family participate in the processing of dsRNA into mature small RNAs residing in the RNA silencing effector complexes. The RNase III-type enzyme, is an endonuclease with specificity for dsRNA (Robertson et al., 1968). It cleaves perfect or nearly perfect dsRNA segments of 20-25 bp in length, leaving 2-3 nt staggered ends (reviewed by (Robertson, 1982; Nicholson, 1999)).

The RNase III-type enzymes can be divided into three classes based on their domain composition (reviewed by (Tomari and Zamore, 2005a)). All of them have at least one RNase III domain (RIIID) and a carboxy-terminal dsRNA-binding domain (dsRBD). Class I of RNase III enzymes, found in bacteria and yeast, have single RIIID and dsRBD domains. Enzymes of the second class contain two tandem RIIIDs and a dsRBD. They are represented by Drosha, a nuclear protein conserved in C. elegans, $D$. 
melanogaster and human. Drosha is involved in the early steps of miRNA biogenesis (Lee et al., 2003). Dicer belongs to the third class of the RNase III enzymes, which contain an amino-terminal helicase domain and a PAZ domain in addition to two tandem RIIIDs and a dsRBD. The Dicers are involved in processing of small RNA and formation of RNA silencing effector complexes. Vertebrates and C. elegans contain single Dicer genes (Dcr-1), while D. melanogaster expresses two (Dcr-1 and Dcr-2) and A. thaliana four (DCL1 to 4) Dicers with specialized functions. In fly, Dcr-1 functions mainly in the processing of miRNA precursors, while Dcr-2 is required for RNAi (Liu et al., 2003; Lee et al., 2004b).

Nucleases Drosha and Dicer require for their function small proteins containing dsRBDs. In fly, Drosha binds Pasha (human DGCR8) (Denli et al., 2004; Gregory et al., 2004; Han et al., 2004; Landthaler et al., 2004), Dcr-1 - Loquacious (Loqs) (Forstemann et al., 2005; Jiang et al., 2005; Saito et al., 2005) and Dcr-2 - R2D2 (Liu et al., 2003; Tomari et al., 2004a; Tomari et al., 2004b). The sole Dicer in C. elegans binds RDE-4 (Tabara et al., 2002) and human Dicer - TRBP (HIV-1 trans-activationresponsive (TAR) RNA-binding protein) (Chendrimada et al., 2005; Haase et al., 2005). TRBP has also been reported to modulate HIV-1 gene expression through association with TAR RNA, to inhibit the interferon-induced dsRNA-regulated protein kinase PKR, and to control cell growth (reviewed by (Bannwarth and Gatignol, 2005)). A mouse TRBP homologue, Prbp, functions as a translational regulator during spermatogenesis, and Prbp-null mice are male sterile and usually die at the time of weaning (Zhong et al., 1999).

\subsubsection{Argonautes}

Members of the Argonaute family are core components of all RNA silencing effector complexes. The Argonaute proteins were initially defined by the presence of two domains, PAZ and Piwi (Cerutti et al., 2000). Therefore, the Argonautes are occasionally referred to as the PAZ-and-Piwi-domain (PPD) proteins.

The Argonautes are the largest conserved family of RNA silencing proteins. There are 10 members of the Argonaute family in A. thaliana, 2 in N. crassa, 24 in $C$. elegans, 5 in D. melanogaster and 8 in human. S. pombe has a single Argonaute protein but $S$. cerevisiae does not have any. Argonautes are encoded as well by a protist Tetrahymena thermophila (Mochizuki et al., 2002), some protozoan parasites (Ullu et 
al., 2004) and simple multicellular animals like jellyfish (Seipel et al., 2004) and sea urchin (Rodriguez et al., 2005).

Argonaute proteins can be divided into two groups - those that resemble $A$. thaliana AGO1 (Ago subfamily), and those that more closely resemble the $D$. melanogaster Piwi (Piwi subfamily) (Carmell et al., 2002). In human, there are four members of the Ago subfamily (Ago1-4) and four members of the Piwi subfamily (Hili and Hiwi, Hiwi2 and Hiwi3) (Sasaki et al., 2003).

\subsubsection{The Ago subfamily}

In D. melanogaster, Ago2 is an essential component of the siRNA-directed RNAi response (Hammond et al., 2001), while Ago1 is involved in miRNA function (Okamura et al., 2004). Members of the Ago subfamily in C. elegans, Rde-1 and PPW1, are involved in dsRNA-mediated silencing (Tabara et al., 1999; Tijsterman et al., 2002b), whereas Alg-1 and Alg-2 are required for miRNAs to repress gene expression (Grishok et al., 2001).

Proteins of the human Ago subfamily share $80 \%$ sequence identity and are ubiquitously expressed in various tissues (Sasaki et al., 2003). All 4 human Agos bind a similar set of endogenous miRNAs, which guides them to their targets (Liu et al., 2004; Meister et al., 2004). Only Ago2 is able to cleave the target, although it requires a nearly perfect guide-target complementarity (Liu et al., 2004; Meister et al., 2004). Since most of the animal miRNAs form bulges with their targets, Agos are proposed to mediate regulation of gene expression mostly by the translational repression, rather than target cleavage (Bartel, 2004).

Mammalian Ago2 protein was first identified in the rabbit reticulocyte lysate, as a component of a high molecular weight complex that promotes ternary complex formation (eIF2-GTP-tRNA(Met)) and stabilizes the complex formed between the ternary complex, 40S ribosomal subunit and mRNA (Roy et al., 1988). Thus, Ago2 was initially named eIF2C, for 'eukaryotic translation initiation factor' (Zou et al., 1998). Interestingly, the role of Agos in the regulation of translational initiation has been recently revisited (Humphreys et al., 2005; Pillai et al., 2005) (see Discussion).

Ago2 from rat was characterized as a membrane-associated cytosolic protein localized to the Golgi apparatus and/or endoplasmic reticulum depending on the cell 
type. Thus, Ago2 also received the name of GERp95, for 'Golgi/ER protein of $95 \mathrm{kDa}$ ' (Cikaluk et al., 1999). Recently, however, the Agos, miRNAs and repressed mRNAs were demonstrated to be enriched in the processing bodies (P-bodies) (Liu et al., 2005b; Pillai et al., 2005; Sen and Blau, 2005). P-bodies are cytoplasmic loci implicated in processing and degradation of the transcripts, as well as their storage (Sheth and Parker, 2003). Both Ago1 and Ago2 were shown to interact with GW182, a key P-body component, and its paralog TNRC6B (Jakymiw et al., 2005; Liu et al., 2005a; Meister et al., 2005).

\subsubsection{The Piwi subfamily}

\subsection{Piwis in fly and worm}

Expression of Piwi and Aubergine (Aub, also known as Sting), the two $D$. melanogaster genes of the Piwi subfamily, is related to the male and female germline development. In the fly, gametogenesis proceeds from germinal stem cells (GSCs) to gametes continuously throughout their lives in both sexes.

Piwi gene was named after its mutant phenotype of 'P-element induced wimpy testis' in D. melanogaster (Lin and Spradling, 1997). Piwi is expressed in the germline and somatic cells in fly gonads of both sexes, and is localized to the nucleoplasm (Cox et al., 2000). Piwi is required for self-renewal and asymmetric division of GSCs (Cox et al., 1998). Prg-1 and Prg-2 Argonaute proteins are the functional homologs of Piwi in C. elegans, being essential for germline proliferation and maintenance (Cox et al., 1998).

Aub is expressed cytoplasmically in the germline of both sexes. During oogenesis, Aub protein, together with a helicase Vasa, localizes to polar granules (Pgranules), where it is implicated in the translational regulation of a subset of ovarian transcripts, including oskar mRNA (Wilson et al., 1996; Harris and Macdonald, 2001; Findley et al., 2003). P-granules are special form of nuage, a cytoplasmic accumulation of material present in animal germ cells. P-granules specify germline fates and certain aspects of somatic patterning in insects (reviewed by (Parvinen, 2005)). Aub is also required for the formation of embryonic pole cells, which are germline precursor cells (Harris and Macdonald, 2001).

Both, Piwi and Aub, are required for small RNA-mediated PTGS events. Piwi is 
required for silencing of the multicopy $A d h$ transgene (Pal-Bhadra et al., 2002) and the endogenous retrovirus gypsy (Sarot et al., 2004). Aub is required for RNAi in oocytes and ovaries (Kennerdell et al., 2002; Tomari et al., 2004a), and is also involved in rasiRNAs-mediated silencing of the Stellate (Ste) genes by the homologous Suppressors of Stellate [Su(Ste)] in fly testes (Schmidt et al., 1999; Aravin et al., 2001; Aravin et al., 2004).

Moreover, Piwi and Aub are required for heterochromatic silencing of tandem repeats. Mutations in either of these genes result in the partial loss of histone H3 lysine K9 methylation (H3-mK9), modification leading to the assembly of a repressive chromatin structure called heterochromatin (Pal-Bhadra et al., 2004).

\subsection{Piwis in mammals}

Expression of the human Piwi subfamily members Hiwi and Hili (mouse Miwi and Mili) is largely male germline specific. However, Piwis may be expressed in other tissues either at much lower levels or only in some specialized cells. For example, Hiwi was reported to be present in human CD34+ hematopoietic progenitor cells but not in more differentiated cell populations (Sharma et al., 2001).

Germ cells are segregated from somatic lineages very early in embryonic life. Primordial germ cells (PGCs), which are the first germ cells specified during embryogenesis, migrate into gonads during embryogenesis and differentiate into GSC, and eventually into gametes in the adult gonad.

In mammals, there are major differences in the way in which gametogenesis in female and male proceeds. In human oogenesis, female GSCs, oogonia, proliferate only in the fetus and the fully developed ovaries are devoid of the germ cells. Oogonia enter meiosis before birth, and become arrested as primary oocytes in the first meiotic prophase, in which state they may remain for up to 50 years. Individual oocytes mature from this strictly limited stock and are ovulated at intervals, generally one at a time, beginning at puberty (reviewed by (Alberts et al., 2002)).

Spermatogenesis in human, by contrast, does not begin until puberty and then goes on continuously. Male GSCs, spermatogonia, proliferate continuously by mitosis, and some of their daughter cells differentiate into primary spermatocytes. These cells enter the division I of meiosis to produce two secondary spermatocytes, which in turn proceed through meiotic division II to produce four spermatids. The spermatids are 
haploid and undergo morphological differentiation into sperm (Fig. 2) (reviewed by (Alberts et al., 2002)).

Hiwi and Miwi, both are expressed in testis germline but not in the ovaries. Hiwi and Miwi are localized cytoplasmically in spermatocytes (Fig. 2) (KuramochiMiyagawa et al., 2001; Qiao et al., 2002). Spermatogenesis in $\mathrm{Miwi}^{-{ }^{-}}$mouse is arrested postmeiotically, at the beginning of spermiogenesis. This phenotypically resembles the mutant of CREM, master regulator of spermiogenesis. Interestingly, Miwi was shown to bind and stabilize mRNA transcripts of ACT (activator of CREM) and of CREM target genes (Deng and Lin, 2002).

Mili is expressed in PGCs of both sexes, and later in testes and ovaries. Expression of Mili in testes persists throughout the mouse adult life, whereas in ovaries it ceases after the birth, concomitantly with the depletion of GSCs from the developing ovaries. Mili is localized cytoplasmically in spermatogonia (male GSCs) and in spermatocytes (Fig. 2) (Kuramochi-Miyagawa et al., 2001). Spermatogenesis in Mili-1mice is arrested in the prophase (zygotene or early pachytene stage) of the first meiotic division, at the stage of early spermatocyte. This resembles the phenotype of the Mvh (mouse Vasa homolog) knockout mice. In fact Mili, as well as Miwi, was demonstrated to associate with Mvh (Kuramochi-Miyagawa et al., 2004). Both Mili- and Miwi-null mice develop into apparently normal adults, which appear to be female fertile but completely male sterile (Deng and Lin, 2002; Kuramochi-Miyagawa et al., 2004). 


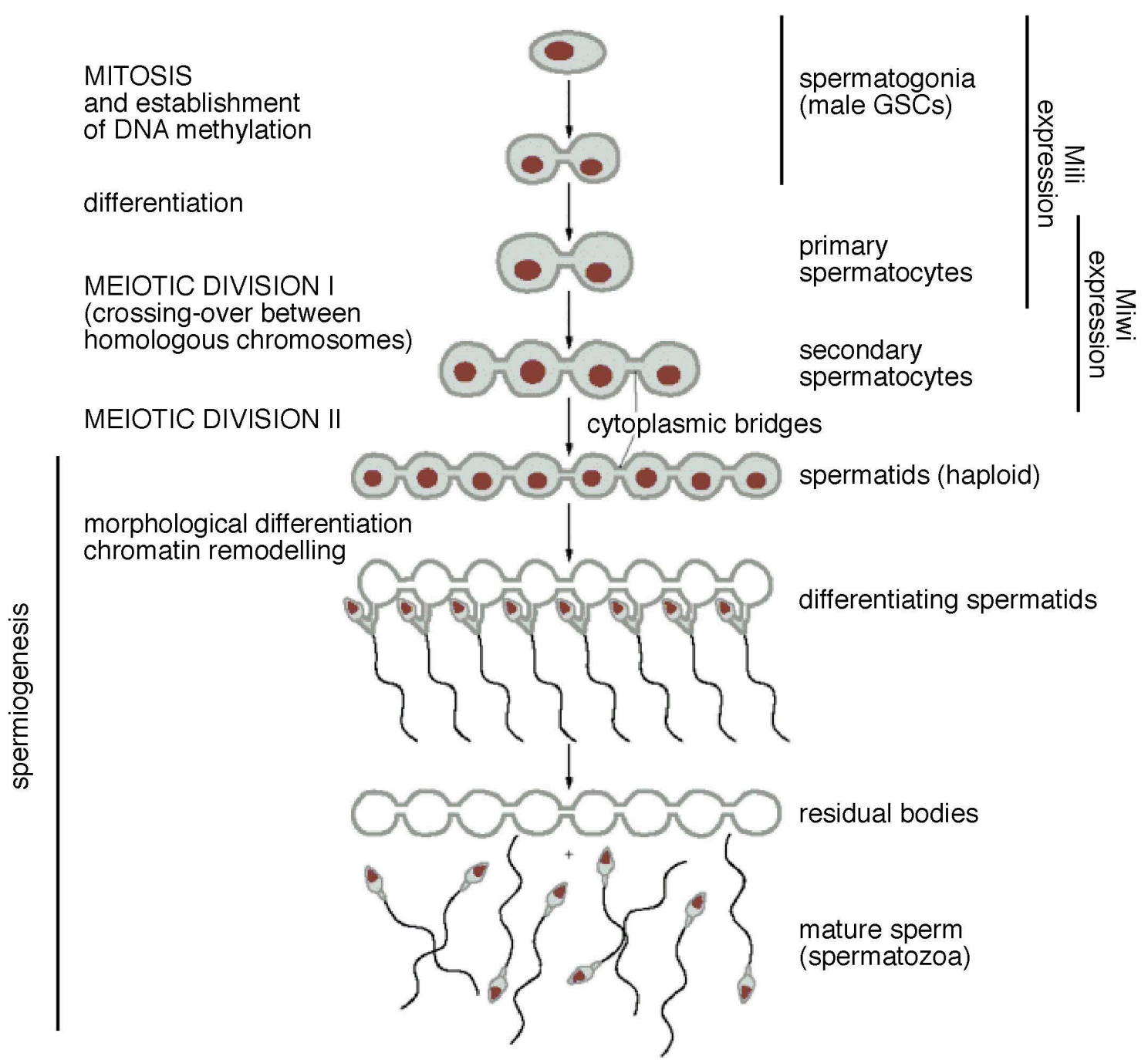

Fig. 2 Spermatogenesis in human (modified from (Alberts et al., 2002)).

Male GSCs, spermatogonia, proliferate continuously by mitosis. Some spermatogonia differentiate into primary spermatocytes. These cells enter the division I of meiosis to produce two secondary spermatocytes, which in turn proceed through meiotic division II to produce four spermatids. The spermatids are haploid and undergo morphological differentiation into sperm. The progeny of a single maturing spermatogonium remain connected to one another by cytoplasmic bridges throughout their synchronous differentiation into mature sperm. In this way, developing haploid sperm, which carries either $\mathrm{X}$ or $\mathrm{Y}$ chromosome, can be supplied with all the products of a complete diploid genome (reviewed by (Alberts et al., 2002)).

Erasure of parental imprinting occurs around the time when PGCs enter the gonad. Imprinting marks are re-established during mitotic proliferation of spermatogonia. The chromatin remodeling takes place during meiosis when specific histone variants are introduced, and continues post-meioticaly when histones are replaced by transition proteins and subsequently by protamines (reviewed by (Rousseaux et al., 2005)).

The expression of Mili and Miwi proteins during spermatogenesis is indicated with the black bars (see text). 


\subsubsection{Structure of Argonautes}

The first reports on structure of PAZ domain from the human and fly Ago proteins compared it to the $\mathrm{OB}$ fold known for binding of oligonucleotides (Lingel et al., 2003; Song et al., 2003; Yan et al., 2003). Subsequent structural studies of the PAZRNA complex established that 3' single-stranded ends of RNA can be specifically positioned within a hydrophobic and aromatic residue-lined cleft of the PAZ domain (Lingel et al., 2004; Ma et al., 2004).

Since then two structures of the Argonaute proteins have been resolved, Pf-Ago from archaebacterium Pyrococcus furiosus (Song et al., 2004), and Aa-Ago from eubacterium Aquifex aeolicus (Yuan et al., 2005), as well as Af-Piwi, an archaeal Piwi protein from Archaeoglobus fulgidus, which is an isolated Piwi domain protein (Parker et al., 2004). The Ago proteins have N, PAZ, Mid and Piwi domains, whereas solo-Piwi protein consists of a Mid and Piwi domains. Despite of having the same domain structure, Pf-Ago and Aa-Ago differ substantially in the overall architecture. The PAZ domain of Pf-Ago is positioned over a crescent-shaped base composed of the N, Mid and Piwi domains (Song et al., 2004), whereas Aa-Ago has a bilobed conformation with the N/PAZ lobe connected to the Mid/Piwi lobe by a short hinge element (Yuan et al., 2005).

The most significant structural discovery, was the identification of an RNase Htype fold within the Piwi domain (Parker et al., 2004; Song et al., 2004), which provided insights into the enzymatic activity of Argonaute proteins. The RNase $\mathrm{H}$ nucleases cleave single-stranded RNA of an RNA/DNA hybrid. The cleavage reaction is $\mathrm{Mg}^{2+}$-dependent and results in products with 3' hydroxyl and 5' phosphate groups, which is consistent with the characteristics of the catalytic activity of RISC (Martinez and Tuschl, 2004; Schwarz et al., 2004). RNase H-fold enzymes contain highly conserved catalytic carboxylates, the 'DDE' motif (Yang and Steitz, 1995). Structural studies supported by experimental mutagenesis established, that catalytic center of the Piwi domain is made of a unique 'DDH' motif that coordinates divalent metal ion (Liu et al., 2004; Song et al., 2004; Rivas et al., 2005; Yuan et al., 2005). The nucleolytic activity of Ago2, however, cannot be explained exclusively by the DDH-motif at the catalytic center of the Piwi domain, since all three putative catalytic residues are preserved as well in the sequence of Ago3, which does not have cleavage activity (Rivas et al., 2005). 


\subsubsection{RNA helicases}

DEXD/H-box helicases are the ATP-dependend RNA/RNA and RNA/protein remodeling enzymes (Rocak and Linder, 2004). In addition to the helicase domain of Dicer protein, many other helicases have been implicated in the RNA silencing processes.

D. melanogaster helicases Armitage (Armi), Spindle-E (Spn-E, also known as homeless) and Dmp68, are all required for RNAi in fly oocytes, ovaries and S2 cells, respectively (Ishizuka et al., 2002; Kennerdell et al., 2002; Tomari et al., 2004a). Armi and Spn-E are required for oskar mRNA localization and silencing, and reorganization of microtubules during fly oogenesis (Cook et al., 2004). Both Armi and Spn-E, are also involved in silencing of the X-linked repetitive Stellate locus in fly testes (Schmidt et al., 1999; Aravin et al., 2001; Stapleton et al., 2001; Tomari et al., 2004a). Moreover, Spn-E is involved in silencing of retrotransposons and other genomic tandem repeats in the germline (Aravin et al., 2001), and is required for heterochromatic silencing (PalBhadra et al., 2004).

Genes mutated in a few RNAi-defective strains of $C$. elegans encode for helicases. These are: Drh-1, Rde-4 interacting partner (Tabara et al., 2002), Mut-14, defective as well in transposon silencing and co-suppression (Tijsterman et al., 2002a), and Smg-2, also required for NMD (Domeier et al., 2000). SDE-3 is a helicase required for PTGS in A. thaliana (Dalmay et al., 2001). Human Gemin3 helicase was found in a complex with miRNAs and Ago2 (Mourelatos et al., 2002).

Biochemical studies suggested that Armi may be involved in unwinding of small dsRNAs during the RISC assembly, since the ovary extract from Armi mutant is defective in assembly of an active RISC (Tomari et al., 2004a). Human homolog of Armi, Mov10, was recently demonstrated to be required for RNAi in the cell culture, to co-localize with RISC components in P-bodies and to co-IP with Ago1 and Ago2 (Meister et al., 2005). Mov10 was suggested to act downstream of Dicer cleavage step, which is consistent with its proposed role in unwinding of small dsRNAs produced by Dicer. Murine Mov10 has been implicated to play a role in development and/or control of cell proliferation (Mooslehner et al., 1991). 


\subsubsection{RdRPs}

RNA-dependent RNA polymerases (RdRPs) synthesize dsRNA on single stranded RNA templates to initiate or amplify the RNA silencing process. There are two modes of action of the RdRP enzymes; in one RdRPs require RNA primers, and in the other, RdRPs perform the unprimed polymerization (reviewed by (Tomari and Zamore, 2005b)). There is a clear requirement for RdRP in RNA silencing pathways in $A$. thaliana (Dalmay et al., 2000; Mourrain et al., 2000), N. crassa (Cogoni and Macino, 1999; Makeyev and Bamford, 2002), S. pombe (Hall et al., 2002; Volpe et al., 2002; Motamedi et al., 2004), C. elegans (Smardon et al., 2000; Sijen et al., 2001) and Dictyostelium discoideum (Martens et al., 2002). RdRP appears to be absent in $D$. melanogaster and mammals (Celotto and Graveley, 2002; Chiu and Rana, 2002; Schwarz et al., 2002; Roignant et al., 2003).

\subsection{DsRNA silencing effector complexes}

\subsubsection{Assembly of catalytically active RISC}

SiRNA duplex is initially incorporated into a RISC loading complex (RLC), which is defined by the presence of the R2D2/Dcr-2 heterodimer in the D. melanogaster lysate (Pham et al., 2004; Tomari et al., 2004a; Tomari and Zamore, 2005b) and the TRBP/Dicer heterodimer in the human cell extracts (Fig. 1) (Chendrimada et al., 2005; Gregory et al., 2005; Haase et al., 2005). R2D2 binds the more thermodynamically stable end of the siRNA duplex while the other end is bound by Dcr-2 (Tomari et al., 2004b). The TRBP/Dicer takes also a part in the assembly of miRNPs (Chendrimada et al., 2005; Gregory et al., 2005).

Subsequently, the RLC associates with Ago2. The Piwi domain of human Ago2 binds directly to the RNase III domain of Dicer (Doi et al., 2003; Tahbaz et al., 2004). Activation of the RISC can proceed in two ways. The passenger strand of siRNA duplex can be cleaved by Ago2, becoming the first substrate of the active RISC (Matranga et al., 2005; Rand et al., 2005). Alternatively, siRNA duplex can be unwound in the ATP-dependent process by a helicase, possibly Armitage (Tomari et al., 2004a).

The active RISC sediments with ribosomes in an 80 S complex dubbed 'holoRISC' (Pham et al., 2004). The holo-RISC is a multi-protein complex, containing dFXR 
(Fragile X mental retardation protein) (Caudy et al., 2002; Ishizuka et al., 2002), VIG (Vasa intronic gene) (Caudy et al., 2002) and Tudor-SN (Tudor staphylococcal nuclease) (Caudy et al., 2003). Notably, proteins contained in the holo-RISC are known from independent studies to interact with and/or regulate translation of mRNAs. Human ortholog of dFXR, FMRP, is involved in translational regulation and transport of mRNA transcripts (reviewed by (Jin et al., 2004)). Human ortholog of VIG, PAI-RBP1, displays affinity for an AU-rich sequence in the 3'-UTR of the plasminogen activator inhibitor (PAI) RNA, and is implicated in regulation of its stability (Heaton et al., 2001). Tudor-SN protein in Xenopus laevis was shown to bind hyper-edited dsRNA and promote its cleavage (Scadden, 2005).

Two complexes recapitulating the pre-miRNA processing and the miRNAguided target cleavage have been isolated recently from human cell extracts. The trimeric Ago2/TRBP/Dicer complex (Gregory et al., 2005), and a larger complex of Ago2 with Dicer, Gemin3 and 4 (Mourelatos et al., 2002), TNRC6B, a homolog of a Pbody protein GW182, helicase Mov10 and an arginine methyltransferase PRMT5 (Meister et al., 2005).

\subsubsection{Target RNA cleavage by RISC}

The minimal RISC that cleaves target RNA complementary to the guide RNA is a 160 kDa complex containing small single-stranded RNA and Ago2 protein (Martinez et al., 2002; Schwarz et al., 2002). RISC is a $\mathrm{Mg}^{2+}$-dependent endonuclease (Martinez and Tuschl, 2004; Schwarz et al., 2004) and its catalytic center is located within the Piwi domain of Ago2 (Liu et al., 2004; Rivas et al., 2005). RISC cleaves the target RNA once, in the middle of region complementary to the guide RNA (Elbashir et al., 2001a), and the cleavage reaction does not require ATP (Nykänen et al., 2001; Haley and Zamore, 2004; Martinez and Tuschl, 2004; Rivas et al., 2005). The guide RNA is presumed to form an A-form helix with the target RNA for the cleavage to occur (Chiu and Rana, 2003; Haley and Zamore, 2004). The 'scissile phosphate' is located opposite the $10^{\text {th }}$ phosphodiester bond of the guide strand, counting from its 5 ' end (Elbashir et al., 2001b). Cleavage by RISC leaves 3' hydroxyl and 5' monophosphate termini (Martinez and Tuschl, 2004; Schwarz et al., 2004). The mRNA cleavage products are subsequently degraded without undergoing decapping or adenylation; 5' mRNA fragments are rapidly degraded from their 3' ends by the exosome, whereas the 3' 
fragments are degraded from their 5' ends by XRN1 (Orban and Izaurralde, 2005). RISC is a multiple-turnover enzyme - the siRNA guides RISC to its RNA target, the target is cleaved and the siRNA remains intact within the RISC (Hutvagner and Zamore, 2002; Haley and Zamore, 2004; Martinez and Tuschl, 2004).

\subsubsection{Composition of the RITS complex}

RITS complex (Verdel et al., 2004) acts in the nucleus where it directs the heterochromatin formation by promoting DNA and/or histone modifications. RITS complex also regulates dsRNA and siRNA synthesis by recruiting an RNA-directed RNA polymerase complex (RDRC) to sites of heterochromatin assembly (Motamedi et al., 2004). The $S$. pombe RITS complex is formed by Ago1, Chp1 and Tas3 proteins, and contains rasiRNAs cognate to the silenced chromatin region (Verdel et al., 2004). Ago1 is the $S$. pombe sole Argonaute protein, and it also mediates the posttranscriptional RNA silencing pathways in yeast (Sigova et al., 2004). Two other components of RITS are much less characterized; Chp1 is a chromodomain-containing centromere-binding protein required for methylation of histone $\mathrm{H} 3$ lysine 9 at the centromeric repeats, and Tas3, a protein of unknown function with a region of similarity to the mouse protein OTT (ovaries and testes transcribed). Reviewed by (Martienssen et al., 2005; Verdel and Moazed, 2005). 


\section{RATIONALE}

In order to get insights into the mechanism of RNAi in human cells, a study of the RNAi effector complex was performed. Both, the small RNA and the Argonaute protein, components of the effector complexes were addressed.

The aim of the first part of the study was to characterize siRNAs in the human cell extract recapitulating the siRNA-mediated target RNA cleavage reaction. Although the standard assay monitored cleavage of the target RNA, the fate of the siRNA trigger was unknown. Thus, the questions of stability and the phosphorylation state of singleand double-stranded siRNAs during the assay were addressed.

At the time, composition of the RISC was unknown. Following the data on single-stranded siRNA-guided target RNA cleavage in the human cell extract (Martinez et al., 2002), RNAi in cell culture was performed. The experiments were designed to test the ability of a single-stranded siRNA to trigger RNAi in cell culture, as well as the influence of the 5' phosphate and the siRNA length on this process.

The aim of the second part of the study was to characterize the family of human Argonaute proteins. It was prompted by the identification of the Ago1 and Ago2 proteins purifying with human RISC (Martinez et al., 2002). Although their precise function was not known, Argonautes were reported to play a role in the effector step of RNAi in all studied organisms. The initial steps aimed to identify all members of the Argonaute family in the human genome, and to determine their expression pattern in cell lines amenable for biochemical studies.

The biochemical system for commonly expressed Ago subfamily members was promptly established (Meister et al., 2004). In the search for functional differences between highly homologous and co-expressed Agos, it remained to be answered whether all of them associate with the same set of miRNAs. In the meantime, the RNAi target cleavage activity was demonstrated to associate solely with Ago2, and not with the other Agos (Meister et al., 2004).

Members of the mammalian Piwi subfamily have not been yet implicated in any 
RNA silencing process. Thus, it was desirable to test, whether they are competent of small RNA-guided target RNA cleavage. Since the cell culture-based biological system for studies of the Piwi subfamily members was not readily identifiable, the target cleavage assays were performed on the Piwis expressed ectopically. In parallel, a set of Piwi members-specific sera was prepared and/or tested in order to continue the studies in the tissue system. 


\section{MATERIALS AND METHODS}

\subsection{Primers and PCR}

Oligodeoxyribonucleotides (ODNs) were synthesized at $0.2 \mu \mathrm{mol}$ scale using standard DNA phosphoramidite reagents (Proligo). ODNs were deprotected for 16 hours at $55^{\circ} \mathrm{C}$ in $1.5 \mathrm{ml} 30 \%$ aqueous ammonia. After removal of the control pore glass support, the ODNs were precipitated by the addition of $12 \mathrm{ml}$ absolute 1-butanol, pellets were collected by centrifugation, dried in a speed-vac, and dissolved in $0.5 \mathrm{ml}$ water.

\subsubsection{Quantitative real-time RT-PCR (qRT-PCR)}

$1 \mu \mathrm{g}$ of total RNA (prepared as described below) was treated with DNase I (Invitrogen) and reverse transcribed using SuperScript III (Invitrogen) with (dT) ${ }_{18}$ for 50 min at $50^{\circ} \mathrm{C}$. Quantitative PCR was performed using HotStar Taq (Qiagen) in HotStar buffer in the presence of $4 \mathrm{mM} \mathrm{MgCl} 2,1 \times$ SYBR Green I (Molecular Probes), 1x ROX reference dye (Invitrogen), 10\% (v/v) DMSO and primers at $0.3 \mu \mathrm{M}$ final concentration. Taq polymerase was activated for $20 \mathrm{~min}$ at $95^{\circ} \mathrm{C}$, followed by 40 cycles of $30 \mathrm{~s} 95^{\circ} \mathrm{C} / 1$ $\min 60^{\circ} \mathrm{C} / 30 \mathrm{~s} 72^{\circ} \mathrm{C}$. PCR was performed on a Stratagene Mx3000P cycler supplied with analytical software. PCR products were verified by analysis of the melting curve and agarose gel separation.

Primers were designed to amplify a region of 110-130 bp spanning an exon/exon junction within mature mRNA, to control for amplification from genomic DNA. As a rule, 3 independent pairs of primers per gene were tested. The primer pairs giving a linear amplification were chosen for further experiments (column marked with '*').

\begin{tabular}{|l|l|l|l|l|l|l|l|}
\hline & gene & exons & forward & db No. & reverse & No. \\
\hline & GAPDH & & CGCTCTCTGCTCCTCCTGTT & 20.109 & CCATGGTGTCTGAGCGATGT & 20.110 \\
\hline \multirow{2}{*}{ Ago1 } & e1/e2 & CCTGACCTCCGCACGGGTAT & 20.114 & GTGCCTGGAACACCTGCTGCA & 21.319 \\
\hline Ago1 & e3/e4 & GCACTGCCCATTGGCAACGAA & 21.322 & CATTCGCCAGCTCACAATGGCT & 22.109 \\
\hline Ago1 & e9/e10 & ACAGGAGGAGATCAGTCGCCT & 21.329 & ACTTTGATCCCAAATTCCTGGAT & 23.99 \\
\hline & Ago2 & e1/e2 & CGGCGGCGCCACCATGTACT & 20.115 & GGCTTGAAGGCATATCCTTGGA & 22.108 \\
\hline \multirow{2}{*}{ Ago2 } & e3/e4 & CATGGTCCAGCACTTTAAAACACA & 24.39 & TGGCAGCGTGACCTCCAGCT & 20.116 \\
\hline Ago2 & e5/e6 & CGCGTCCGAAGGCTGCTCTA & 20.117 & TGGCTGTGCCTTGTAAAACGCT & 22.111 \\
\hline & Ago3 & e1/e2 & TCCGTTCTCCCTCGAAGCACT & 21.320 & GGTCTTCTGGGCACCATGAGT & 21.321 \\
\hline Ago3 & e6/e7 & CATAATATTGATGAGCAACCAAGA & 24.40 & TCCGTCTCATTGTTCCACAATGA & 23.48 \\
\hline * Ago3 & e4/e5 & GGAATTAGACAAGCCAATCAGCA & 23.49 & AGGGTGGTCATATCCTTCTGGA & 22.112 \\
\hline
\end{tabular}


MATERIALS AND METHODS

\begin{tabular}{|c|c|c|c|c|c|c|}
\hline & Ago3 & e3/e4 & TCСАСTTCCTGTGGCAACTACA & 22.120 & GCCAACTCACCCGAGAGACAA & 21.330 \\
\hline & Ago4 & e3/e4 & АTCCACTACCAATTGGACGGGAT & 23.47 & CCACTGAACAGACACTTTAAATGT & 24.38 \\
\hline \multirow[t]{3}{*}{ * } & Ago4 & e6/e7 & CTAACAGACTCCCAGCGTGTCA & 22.110 & GACTGGCTGGCCGTCTAGTCA & 21.323 \\
\hline & $\mathrm{Hili}$ & e1/e2 & GAGGCCATGTATTTGGAAAGCCA & 23.103 & CAATGCCCAGGCCTCGGAACA & 21.333 \\
\hline & Hili & e3/e4 & CAAGATGGCAGAGACCTCCGTT & 22.121 & GTACAGGGAGGCTTGTCCACTT & 22.122 \\
\hline \multirow[t]{3}{*}{ * } & Hili & e5/e6 & CCTCGTCAAAATACAGTGTCATA & 23.104 & CAACATGCCGAACCTCATGCT & 21.334 \\
\hline & Hiwi & e1/e2 & CGCAGCTGGTGGGCTCCACT & 20.121 & TCTCTGCCGTCCACGGCCAAA & 21.331 \\
\hline & Hiwi & e3/e4 & GTGAATACAAGGCAGAACCTAGA & 23.100 & GACGGGATGTCAGCCGGAAAT & 21.332 \\
\hline \multirow[t]{5}{*}{ * } & Hiwi & e5/e6 & АCATCACCAACTTGTTTGCAGTT & 23.101 & GACTTGGAATATCAATTGGGTCA & 23.102 \\
\hline & Hiwi2 & e1/e2 & GCATCCAAGCCTCGCCATT & 19.32 & GATCCTGCTTGTTCCCAAGA & 20.111 \\
\hline & Hiwi2 & e3/e4 & CAAACAGGACTTTATGGATT & 20.112 & GTTTCACAGGTATTCCACT & 19.33 \\
\hline & Hiwi2 & e4/e5 & GCATTCGACGGTGCCATCCT & 20.113 & TСССTCTTCAGGGTGATAGTC & 21.313 \\
\hline & Hiwi2 & e2/e3 & GTAACAATGAAGCATCCTCTAGCA & 24.45 & АСАССТСTTTCCATGAAGGTACTT & 24.46 \\
\hline \multirow[t]{2}{*}{ * } & Hiwi2 & e5/e6 & TGAAACTCAAAGAGGTGAGACTA & 23.107 & GTACATGGACAACTTTTTGAGGA & 23.108 \\
\hline & Hiwi3 & e3/e4 & CCGCAGGGAGAGCTACCAACA & 21.337 & ССАСТGGGACTTССТССTGCA & 21.338 \\
\hline * & Hiwi3 & e5/e6 & GTGAACACCAGGCAAGATATGAA & 23.105 & CCACTGAGGACGAGATATCACT & 22.123 \\
\hline * & Hiwi3 & e7/e8 & GTCGCCAGATTGCCTACGCTA & 21.339 & CGGTATAACTGAATGGCCTTCTT & 23.106 \\
\hline
\end{tabular}

\subsubsection{Semi-quantitative PCR}

Semi-quantitative PCR was performed on the 70 bp PCR-amplified small RNA cDNA library with a forward primer specific to the 5' adaptor sequence and reverse primers specific to the 3 ' portion of individual miRNAs. This approach, similar to the one described by (Lim et al., 2003), has a disadvantage resulting from a frequent variability of the 3' end of miRNAs. This may lead to some mismatches in the middle

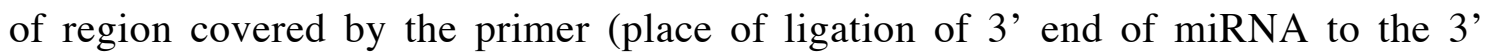
adaptor). The alternative approach is to design forward primers that cover the 5 ' portion of individual miRNAs, and the reverse primer that is adaptor specific and invariant for all reactions.

\begin{tabular}{|l|l|l|}
\hline & forward primer & $\mathrm{db}$ No \\
\hline $5^{\prime}$ adaptor & AGGGAGGCACCGATGCGG & 18.127 \\
\hline & & \\
\hline & reverse primers & $\mathrm{db}$ No \\
\hline let-7a & GCGGTTAAAACTATACAACCT & 21.483 \\
\hline mir-16 & GCGGTTAAAGCCAATATTTAC & 21.484 \\
\hline mir-21 & GCGGTTAAATCAACATCAGTC & 21.485 \\
\hline mir-24 & GCGGTTAAACTGTTCCTGCT & 20.131 \\
\hline mir-19b-1 & GCGGTTAAATCAGTTTTGCATG & 22.147 \\
\hline mir-91 & GCGGTTAAACTACCTGCACT & 20.137 \\
\hline mir-25 & GCGGTTAAATCAGACCGAGA & 20.138 \\
\hline mir-27a & GCGGTTAAAGCGGAACTTAG & 20.139 \\
\hline mir-32 & GCGGTTAAAGCAACTTAGTAA & 21.491 \\
\hline
\end{tabular}




\begin{tabular}{|l|l|l|}
\hline mir-92 & GCGGTTAAAACAGGCCGGG & 19.45 \\
\hline mir-96 & GCGGTTAAAGCAAAAATGTGCT & 22.148 \\
\hline mir-124a & GCGGTTAAATGGCATTCACC & 20.140 \\
\hline
\end{tabular}

\subsection{RNA synthesis and labeling}

\subsubsection{RNA oligos}

Oligoribonucleotides, including siRNAs, unless otherwise indicated, were chemically synthesized using RNA phosphoramidites (Proligo, Hamburg, Germany), deprotected and gel purified as described in (Elbashir et al., 2001b).

Four $21 \mathrm{nt}$ oligoribonucleotides of the same sequence were prepared, differing in the phosphorylation state of their termini. $3^{\prime}$ terminal ${ }^{32} \mathrm{pCp}$ labeling was performed in a $30 \mu \mathrm{l}$ reaction (17 $\mu \mathrm{M}$ siRNA, $0.5 \mu \mathrm{M}{ }^{32} \mathrm{pCp}$ (110 TBq/mmol), 15\% DMSO, $20 \mathrm{U}$ T4 RNA ligase (NEB) in NEB-supplied reaction buffer) for 1.5 hour at $37^{\circ} \mathrm{C}$ and gel purified. One half of the pCp-labeled RNA was dephosphorylated (25 $\mu 1$ reaction, 500 $\mathrm{U}$ alkaline phosphatase (Roche) in Roche-supplied reaction buffer) for $30 \mathrm{~min}$ at $50^{\circ} \mathrm{C}$, followed by phenol/chlorophorm extraction and ethanol precipitation. Half of this reaction was 5' phosphorylated (20 $\mu$ 1 reaction, $10 \mathrm{mM}$ ATP, $2 \mathrm{U}$ T4 polynucleotide kinase (PNK) (NEB) in NEB-supplied reaction buffer) for $60 \mathrm{~min}$ at $37^{\circ} \mathrm{C}$. A quarter of the initial pCp-labeled siRNA was also 5' phosphorylated (10 $\mu 1$ reaction, $10 \mathrm{mM}$ ATP, 10 U 3' phosphatase-free T4 PNK (Roche) in Roche-supplied buffer) for 3 min at $37^{\circ} \mathrm{C}$.

\subsubsection{Target RNA}

For mapping of target RNA cleavage a $177 \mathrm{nt}$ transcript of a fragment of luciferase gene (GL2) was generated, as described in (Elbashir et al., 2001c). 7-Methylguanosine cap-labeling of the RNA cleavage substrate was performed as described in (Elbashir et al., 2001b) using guanylyl transferase (plasmid generously provided by $\mathrm{J}$. Wilusz). Labeled RNA was gel purified. Length standards were generated by partial base hydrolysis (OH ladder) or partial RNase T1 digestion (T1 ladder) of the caplabeled cleavage substrate. 


\subsubsection{Duplex and single-stranded siRNAs against lamin A/C}

SiRNAs were synthesized as described above for oligoribonucleotides. If 5, phosphate was to be introduced, 50 to $100 \mathrm{nmol}$ of synthetic siRNA was treated with T4 polynucleotide kinase (PNK) (300 $\mu 1$ reaction, $2.5 \mathrm{mM}$ ATP, $70 \mathrm{mM}$ Tris- $\mathrm{HCl}$ [pH 7.6], $10 \mathrm{mM} \mathrm{MgCl}_{2}, 5 \mathrm{mM}$ DTT, $30 \mathrm{U}$ T4 PNK (NEB), $45 \mathrm{~min}$ at $37^{\circ} \mathrm{C}$ ) followed by ethanol precipitation. Annealing of siRNA to form duplexes was performed as detailed in (Elbashir et al., 2002).

\begin{tabular}{|l|l|l|l|}
\hline gene & strand & sequence & db No. \\
\hline GL2 & s & CGUACGCGGAAUACUUCGAAA & 21.6 \\
\hline GL2 & as & UCGAAGUAUUCCGCGUACGUG & 21.7 \\
\hline Lam A/C & s & CUGGACUUCCAGAAGAACAtt* & 21.64 \\
\hline Lam A/C & as & UGUUCUUCUGGAAGUCCAGtt* & 21.65 \\
\hline Lam A/C & as & UGUUCUUCUGGAAGUCCAGUUCCUCCUUC & 29.7 \\
\hline Lam A/C & as & UGUUCUUCUGGAAGUCCAGUUCCUCCU & 27.8 \\
\hline Lam A/C & as & UGUUCUUCUGGAAGUCCAGUUCCUC & 25.13 \\
\hline Lam A/C & as & UGUUCUUCUGGAAGUCCAGUUCC & 23.30 \\
\hline Lam A/C & s & CUGGACUUCCAGAAGAACAUC & 21.247 \\
\hline Lam A/C & as & UGUUCUUCUGGAAGUCCAGUU & 21.248 \\
\hline Lam A/C & as & UGUUCUUCUGGAAGUCCAG & 19.16 \\
\hline Lam A/C & as & UGUUCUUCUGGAAGUCC & 17.12 \\
\hline Lam A/C & as & UGUUCUUCUGGAAGU & 15.4 \\
\hline Lam A/C & as & UGUUCUUCUGGAA & 13.6 \\
\hline *tt indicates deoxythymidine nucleotides &
\end{tabular}

\subsubsection{SiRNA duplexes directed against Ago genes}

Four siRNA duplexes per target were designed and provided in collaboration with Dharmacon, Inc. to specifically knockdown individual Ago subfamily members. SiRNAs were composed of 21-nt all-ribo strands, and the antisense strand was 5' phosphorylated. SiRNA duplexes were used in pools of four directed against the same target to increase efficiency while minimizing the off-target effects.

\begin{tabular}{|l|l|l|l|}
\hline Gene-duplex no. & Localization & Sense strand & Antisense strand \\
\hline Ago1-1 & ORF & GAGAAGAGGUGCUCAAGAAUU & pUUCUUGAGCACCUCUUCUCUU \\
\hline Ago1-2 & ORF & GGAAACAGUUCUACAAUGGUU & pCCAUUGUAGAACUGUUUCCUU \\
\hline Ago1-3 & $3{ }^{\prime}$ UTR & GCUGUUACCUCACUGGAUAUU & pUAUCCAGUGAGGUAACAGCUU \\
\hline Ago1-4 & 3 'UTR & GGAGUUACUUUCAUAGCAUUU & pAUGCUAUGAAAGUAACUCCUU \\
\hline Ago2-1 & ORF & GCACGGAAGUCCAUCUGAAUU & pUUCAGAUGGACUUCCGUGCUU \\
\hline AgO2-2 & ORF & GCAGGACAAAGAUGUAUUAUU & pUAAUACAUCUUUGUCCUGCUU \\
\hline
\end{tabular}




\begin{tabular}{|c|c|c|c|}
\hline Ago2-3 & 3'UTR & GGGUCUGUGGUGAUAAAUAUU & pUAUUUAUCACCACAGACCCUU \\
\hline Ago2-4 & 3'UTR & GUAUGAGAACCCAAUGUCAUU & pUGACAUUGGGUUCUCAUACUU \\
\hline Ago3-1 & ORF & GAAAUUAGCAGAUUGGUAAUU & PUUACCAAUCUGCUAAUUUCUU \\
\hline Ago3-2 & ORF & CAAGAUACCUUACGCACAAUU & pUUGUGCGUAAGGUAUCUUGUU \\
\hline Ago3-3 & 3'UTR & GCAUCAUUAUGCAAUAUGAUU & pUCAUAUUGCAUAAUGAUGCUU \\
\hline Ago3-4 & 3'UTR & GCACAACUAUCUUUGCAAAUU & pUUUGCAAAGAUAGUUGUGCUU \\
\hline Ago4-1 & ORF & GGCCAGAACUAAUAGCAAUUU & pAUUGCUAUUAGUUCUGGCCUU \\
\hline Ago4-2 & ORF & CCACUCGGAUCAUCUAUUAUU & pUAAUAGAUGAUCCGAGUGGUU \\
\hline Ago4-3 & $3^{\prime}$ UTR & AGAUGAGAUUUCAGUAUGAUU & pUCAUACUGAAAUCUCAUCUUU \\
\hline Ago 4-4 & $3^{\prime}$ UTR & GAACCAGGAUGCUUCCUUAUU & pUAAGGAAGCAUCCUGGUUCUU \\
\hline
\end{tabular}

\subsection{Target cleavage assays}

\subsubsection{HeLa S100 extract-based target cleavage assay}

If not otherwise indicated, 5' phosphorylated siRNA or siRNA duplex was preincubated in supplemented HeLa S100 extract at $30^{\circ} \mathrm{C}$ for 15 min prior to addition of cap-labeled target RNA. After addition of all components, final concentrations were $100 \mathrm{nM}$ siRNA, $10 \mathrm{nM}$ target RNA, $1 \mathrm{mM}$ ATP, $0.2 \mathrm{mM}$ GTP, $10 \mathrm{U} / \mathrm{ml}$ RNasin, 30 $\mu \mathrm{g} / \mathrm{ml}$ creatine kinase, $25 \mathrm{mM}$ creatine phosphate, and 50\% S100 extract. Incubation was continued for 2.5 hour. Cleavage reactions were deproteinized, phenol/chloroform extracted and the reaction products were separated on a $6 \%$ sequencing gel.

\subsubsection{Anti-FLAG bead-based target cleavage assay}

$10 \mu 1$ of Argonaute complex, immunoprecipitated on anti-FLAG antibodycoupled beads (prepared as described below), was preincubated with $100 \mathrm{nM}$ singlestranded, 5'-phosphorylated siRNA or DNA oligo for $30 \mathrm{~min}$ at $30^{\circ} \mathrm{C}$. The beads were subsequently mixed with cap-labeled target RNA in $25 \mu 1$ cleavage reaction containing $1 \mathrm{mM}$ ATP, $0.2 \mathrm{mM}$ GTP, $10 \mathrm{U}$ RNasin (Promega) in $100 \mathrm{mM} \mathrm{NaCl}, 1.5 \mathrm{mM} \mathrm{MgCl}_{2}$ or $\mathrm{MnCl}_{2}, 0.5 \mathrm{mM} \mathrm{DTT}$, and $10 \mathrm{mM}$ HEPES-KOH at $30^{\circ} \mathrm{C}$ for 1.5 hour. Cleavage reactions were deproteinized, phenol/chloroform extracted and the reaction products were separated on an $8 \%$ sequencing gel. 


\subsection{Cell culture-based assays}

\subsubsection{Cell culture}

HeLa SS6, HeLa S3 and HEK 293 cells were grown in Dubelco's modified Eagle's medium (DMEM) supplemented with 10\% fetal bovine serum (FBS), 100 unit $/ \mathrm{ml}$ penicillin, and $100 \mu \mathrm{g} / \mathrm{ml}$ streptomycin at $37^{\circ} \mathrm{C}$ in humidified atmosphere containing $5 \% \mathrm{CO}_{2}$.

\subsubsection{RNAi knockdown}

One day before transfection cells were plated in $500 \mu 1$ DMEM containing $10 \%$ FBS at the density of $10^{5}$ cells per well of a 24 -well plate. Transfection was carried out with Oligofectamine (Invitrogen) or Lipofectamine2000 (Invitrogen) following manufacturer's recommendations. For transfection of a single well, reagents were complexed with 60 pmol of siRNA duplex or 120 pmol single-stranded siRNA.

\subsubsection{Cell imaging}

\subsubsection{Immunofluorescent staining}

HeLa SS6 cells grown on glass coverslips in 24-well plates, were fixed in methanol chilled to $-10^{\circ} \mathrm{C}$ for $6 \mathrm{~min}$ and washed three times in phosphate-buffered saline (PBS, (Sambrook and Russell, 2001)). Immunostaining of lamin A/C was performed by incubation with an anti-lamin A/C monoclonal antibody (clone 636, kindly provided by Mary Osborn) diluted appropriately in PBS containing $0.5 \mathrm{mg} / \mathrm{ml}$ BSA and $0.02 \%$ sodium azide, for 1 hour at $37^{\circ} \mathrm{C}$. After washing 3 times for $5 \mathrm{~min}$ in PBS, anti-mouse Cy3-labeled secondary antibody appropriately diluted was applied and left incubating for $45 \mathrm{~min}$ at $37^{\circ} \mathrm{C}$. After repeated washing step, chromatin was stained during 4 min incubation in $1 \mu \mathrm{M}$ Hoechst 33342 (Serva) solution in PBS. Coverslips were mounted on slides in Moviol (Hoechst).

\subsubsection{Microscopy}

Pictures were taken using a Zeiss Axiophot with an F Fluar 40x/1.30 oil objective and MetaMorph Imaging Software (Universal Imaging Corporation, West Chester, PA) with equal exposure times for the silenced and the control-treated cells. 


\subsection{Mammalian system for protein expression}

The open reading frames (ORFs) of Ago subfamily members were obtained as described in (Meister et al., 2004); Hili, Hiwi and Hiwi2 were ordered from RIKEN; Hiwi3 was amplified from the human testis Marathon library (Clontech). To generate FLAG/HA-tagged Argonautes, the ORFs were cloned into a modified pIRESneo plasmid (Clontech) (Malik and Roeder, 2003) containing an N-terminal FLAG/HA tag.

\subsubsection{Calcium phosphate transfection}

Two hours prior to transfection, HEK 293 cells were plated at $50 \%$ confluency on a $10 \mathrm{~cm}$ dish in a standard culture medium. 5-10 $\mu \mathrm{g}$ of plasmid DNA was diluted in $438 \mu 1$ water and $61 \mu 12 \mathrm{M} \mathrm{CaCl}_{2} .500 \mu 12 \mathrm{x}$ HEPES-buffered saline $(274 \mathrm{mM}$ $\mathrm{NaCl} / 1.5 \mathrm{mM} \mathrm{Na}_{2} \mathrm{HPO}_{4} / 54.6 \mathrm{mM}$ HEPES-KOH [pH 7.1]) was added drop-wise under gentle agitation. The transfection solution was then drop-wise added onto the cells.

\subsubsection{Establishing cell lines}

HeLa S3 cell lines stably expressing FLAG/HA-tagged human Ago proteins were generated as described in (Malik and Roeder, 2003).

\subsection{Cell extracts and protein purification}

\subsubsection{Preparation of cell extracts}

\subsubsection{NP40-based protein extraction}

Cells growing in the monolayer culture were washed with PBS and lysed on plate with the NP40-based buffer (150 mM NaCl/0.5\% NP40/1 mM EDTA/50 mM Tris- $\mathrm{HCl}$ [pH 7.5]) for $15 \mathrm{~min}$ at $4^{\circ} \mathrm{C}$. Lysed cells were scraped off the plate, collected and spun down in a refrigerated table-top centrifuge for $20 \mathrm{~min}$ at the full speed. The supernatant was collected and used for subsequent assays.

\subsubsection{Cytoplasmic extract}

Cytoplasmic fraction of HeLa S3 cells was prepared by hypotonic swelling following the Dignam protocol (Dignam et al., 1983) with the following modifications. $5 \times 10^{9}$ suspension culture HeLa S3 cells were collected by centrifugation and washed 
with PBS [pH 7.4]. The cell pellet (approx. $15 \mathrm{ml}$ ) was resuspended in five pellet volumes of $10 \mathrm{mM} \mathrm{KCl} / 1.5 \mathrm{mM} \mathrm{MgCl} / 2.5 \mathrm{mM}$ dithiothreitol/10 mM HEPES-NaOH [pH 7.9]/0.5 mM AEBSF and incubated for $10 \mathrm{~min}$ on ice and collected again by centrifugation. The cell pellet was resuspended in 2 pellet volumes of the buffer described above and homogenized by douncing. The cell nuclei were removed from the cell lysate by centrifugation at $1,000 \mathrm{~g}$ for $10 \mathrm{~min}$. The supernatant was cleared further by ultracentrifugation for $30 \mathrm{~min}$ at $30,000 \mathrm{~g}$ to obtain the cytoplasmic extract. The concentration of $\mathrm{KCl}$ and $\mathrm{MgCl}_{2}$ was subsequently raised to $10 \mathrm{mM}$ and $2 \mathrm{mM}$, respectively. The extract was supplemented with glycerol to final concentration of $10 \%$ to allow for freeze storage. The supplemented extract sustained its activity stored frozen at $-70^{\circ} \mathrm{C}$ after quick-freezing in liquid nitrogen. For extract preparation using transiently transfected HEK 293 cells, 10 to 20 confluent $10 \mathrm{~cm}$ plates were used.

\subsubsection{S100 extract}

The S100 extract was prepared by ultracentrifugation of the cytoplasmic extract at $100,000 \mathrm{~g}$ (31.500 rpm using a Sorvall T-865 rotor) for 1 hour. The protein concentration of HeLa S100 extract varied between 4 and $5 \mathrm{mg} / \mathrm{ml}$, as determined by Bradford assay.

\subsubsection{Anti-FLAG immunoprecipitation (IP)}

For purification of FLAG/HA-tagged complexes, cytoplasmic extracts were cleared by centrifugation at $17,200 \mathrm{~g}$ for $30 \mathrm{~min}$ and a passage through a $0.45 \mu \mathrm{m}$ HT Tufryn membrane filter (Pall Corp.). $300 \mu 1$ FLAG M2 agarose beads (Sigma) was washed once with $0.1 \mathrm{M}$ glycine- $\mathrm{HCl}[\mathrm{pH} 8.0]$ and equilibrated by washing with $1 \mathrm{M}$ Tris- $\mathrm{HCl}[\mathrm{pH} 8.0]$. The beads were then resuspended in $300 \mu 1$ buffer $\mathrm{C}(0.1 \mathrm{M} \mathrm{KCl}, 5$ $\mathrm{mM} \mathrm{MgCl}_{2}, 10 \%$ glycerol, 10\% Tween20, $10 \mathrm{mM}$ ß-mercaptoethanol, $0.2 \mathrm{mM}$ PMSF, and $20 \mathrm{mM}$ Tris- $\mathrm{HCl}[\mathrm{pH} 8.0])$ and incubated with approximately $10 \mathrm{ml}$ cytoplasmic extracts for 4 hours at $4^{\circ} \mathrm{C}$ with rotation. The beads were collected and washed with 300 $\mathrm{mM} \mathrm{NaCl} / 5 \mathrm{mM} \mathrm{MgCl} / 2 / 0.1 \%$ NP40/50 mM Tris-HCl [pH 7.5] followed by a wash with buffer C. Affinity-bound complexes were then eluted by shaking the beads in $300 \mu \mathrm{l}$ of $2 \mathrm{mg} / \mathrm{ml} 3 \mathrm{xFLAG}$ peptide (Sigma) in buffer $\mathrm{C}$ for 2 hours at $10^{\circ} \mathrm{C}$. To isolate bound RNA, $100 \mu 1$ of the eluate was treated with proteinase $\mathrm{K}$, phenol/chlorophorm extracted, ethanol precipitated and resuspended in $20 \mu 1$ water. 


\subsubsection{Western blotting}

\subsubsection{Procedure}

Cells or protein samples were solubilized by boiling in SDS sample buffer, separated by SDS-PAGE and transferred onto a nitrocellulose membrane (AmershamBiosciences) by electroblotting. Upon immunostaining with specific antibodies and peroxidase-conjugated secondary antibody, the signal was visualized by the enhanced chemiluminescence (ECL) kit according to the manufacturer's protocol (AmershamBiosciences). ECL signal was acquired using Lumi-Imager (Roche) and quantification was performed using LumiAnalyst software (Amersham Biosciences). Blots were stripped with Western Blot Stripping Buffer (Pierce).

\subsubsection{Antibodies}

Anti-lamin A/C (clone 636) and anti-vimentin V9 primary monoclonal antibodies were kindly provided by Mary Osborn. As secondary antibody, peroxidaseconjugated antibodies (DAKO) were used.

\subsection{RNA extraction}

\subsubsection{Extraction of total RNA}

Total RNA was extracted using the acidic guanidinium thiocyanatephenol/chloroform method (Chomczynski and Sacchi, 1987). This method enables retaining small RNA species in the sample and thus was used to prepare RNA for small RNA cloning.

\subsubsection{Isolation of longer RNA}

Longer RNA, such as mRNA transcripts, was isolated using RNeasy column kit (Qiagen) and was used for qRT-PCR during profiling and knockdown validation experiments.

\subsubsection{Deproteinization}

Enzymatic reactions were quenched by the addition of 8 volumes of $2 x$ proteinase $\mathrm{K}$ buffer (200 mM Tris- $\mathrm{HCl}$ [pH 7.5], $25 \mathrm{mM}$ EDTA, $300 \mathrm{mM} \mathrm{NaCl}$, and 
$2 \% \mathrm{w} / \mathrm{v}$ SDS). Subsequently, proteinase $\mathrm{K}$ dissolved in $50 \mathrm{mM}$ Tris- $\mathrm{HCl}$ [pH 8.0], 5 $\mathrm{mM} \mathrm{CaCl}{ }_{2}$ and $50 \%$ glycerol was added to a final concentration of $0.6 \mathrm{mg} / \mathrm{ml}$ and reactions were incubated for $15 \mathrm{~min}$ at $65^{\circ} \mathrm{C}$. RNA was extracted with phenol/chloroform/isoamyl alcohol [25:24:1], precipitated with 3 volumes of ethanol and resuspended in water.

\subsection{Small RNA cloning}

Total RNA $(80 \mu \mathrm{g})$ isolated from HeLa S3 or HEK 293 cells was separated on a $15 \%$ denaturating polyacrylamide gel, 19-24 nt small RNAs were recovered and used as input for adaptor ligation. $8 \mu \mathrm{l}$ of the $20 \mu \mathrm{l}$ of RNA isolated from the FLAG/HA-tagged Ago complexes was used for library construction without further gel purification. Adaptor ligation and RT-PCR of the ligation product was performed as described in (Pfeffer et al., 2003) with the following modifications. The 5' adenylated 3' adaptor oligodeoxyribonucleotide (5'AppTTTAACCGCGGCACCAGL; Ap, adenylate; p, phosphate; L, C7-3'-aminolinker (ChemGenes)) was ligated to the small RNA fraction in the absence of ATP using T4 RNA ligase Rnl2(1-249) (Ho et al., 2004) kindly provided by Stewart Shuman. The gel-purified ligation product was then joined to the 5' adaptor oligoribonucleotide (5'AGGGAGGCACCGATGCGG) using standard T4 RNA ligase (NEB) and followed by gel-purification. RT-PCR was performed using primers 5'TGCTGGTGCCGCGGTTAAA and 5'AGGGAGGCACCGATGCGG.

\subsection{Production of antisera}

To generate the antigenic Hiwi3 protein fragment contained in all of the Hiwi3 variants, the sequence coding for amino acids 124-276 was chosen (Fig. 15.A). It was subcloned into a bacterial expression vector containing the N-terminal 10xHis-tag (pET-16b, Novagen) and expressed in BL21 Star (DE3) E. coli. Recombinant protein was purified on a nickel resin (Ni-NTA, Qiagen) accordingly to the manufacturer protocol and $5 \mathrm{mg}$ of it was sent out to Upstate Inc., where it was used to immunize 3 rabbits. 


\section{RESULTS}

\subsection{Fate of single- and double-stranded siRNAs in human cell extract and cultured cells}

\subsubsection{SiRNA duplexes in the HeLa S100 extract are stable and bear 5' $P$ and 3' OH termini}

The target RNA cleavage activity of human RISC can be demonstrated in an in vitro assay based on HeLa cell S100 extract (Martinez et al., 2002). In this assay RISC is programmed with an exogenous siRNA duplex to guide the cleavage of a cognate ${ }^{32} \mathrm{P}$ cap-labeled target transcript. The fate of siRNAs in the conditions of the RISC cleavage reaction was unknown. Thus, I addressed the question of siRNA stability and the phosphorylation state during the time-course of the 2-hour cleavage assay in HeLa cell S100 extract.

In D. melanogaster lysate, siRNAs generated from the long dsRNA bear 5' monophosphate and 3' hydroxyl groups, the signatures of RNase III Dicer cleavage products (Elbashir et al., 2001b). Synthetic siRNA duplexes with hydroxyl termini, however, can still efficiently guide target cleavage in the fly lysate, since the 5' hydroxyl groups are rapidly phosphorylated by an endogenous kinase (Nykänen et al., 2001). SiRNA duplexes bearing hydroxyl termini are also active in the HeLa S100 extract (Martinez et al., 2002).

Four radioactively labeled $21 \mathrm{nt}$ RNA oligonucleotides were designed, antisense to the target RNA transcript and differing in the phosphorylation state of their termini (Fig. 3A and B). The constructed RNAs had distinct mobilities when resolved on a $15 \%$ sequencing gel (Fig. 3C). The four different antisense strands were used as singlestranded siRNAs or as siRNA duplexes with 2 nt 3'-overhangs. To obtain siRNA duplexes, the antisense strands were annealed to a complementary strand bearing hydroxyl termini. 


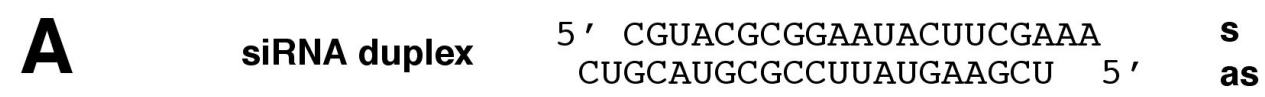

B

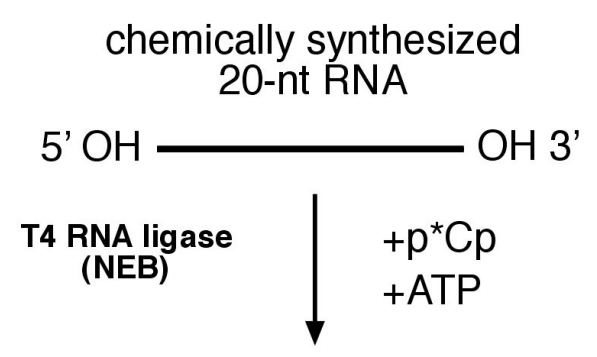

21-nt labeled RNA
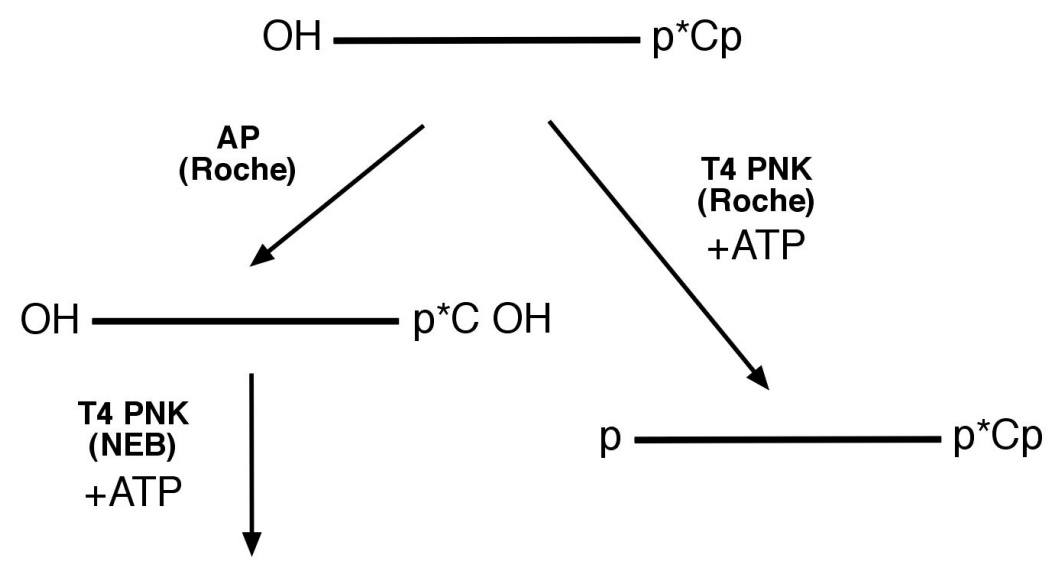

$\mathrm{p} \longrightarrow \mathrm{p}^{\star} \mathrm{COH}$
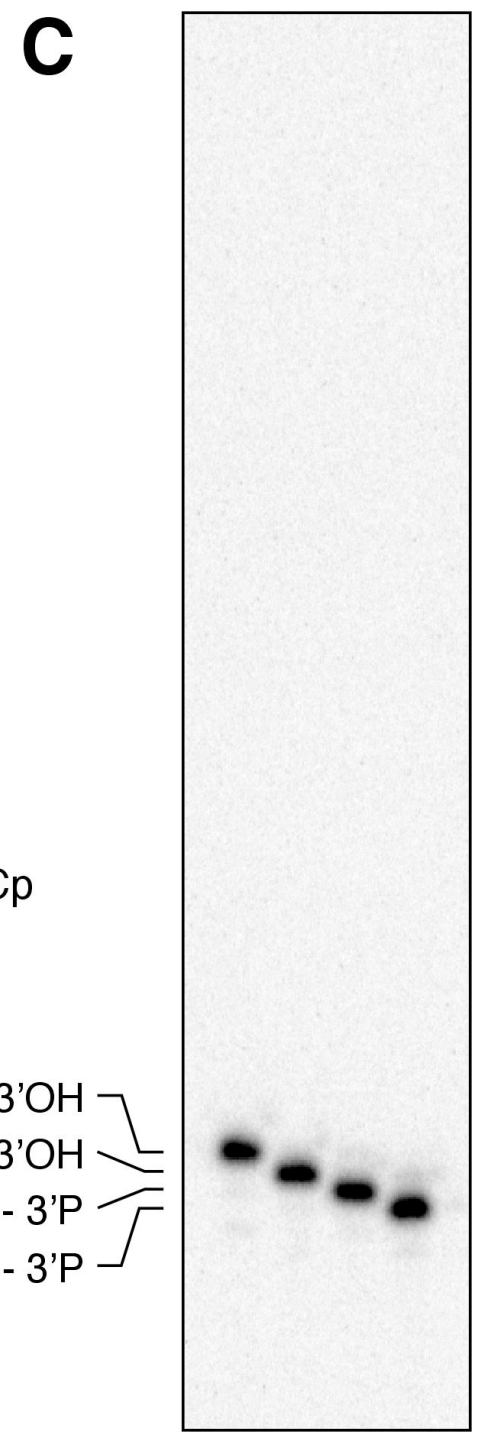

Fig. 3 Preparation and detection of the four, modificated antisense siRNA strands.

(A) Sequence of the siRNA duplex made of antisense (as) and sense (s) strands used in the following experiments.

(B) Generation of the four radioactively labeled $21 \mathrm{nt}$ long RNA oligonucleotides antisense to the target RNA transcript and differing in the phosphorylation state of their termini.

(C) The four different strands of the antisense siRNA were distinguished based on their mobility in the $15 \%$ sequencing gel. 
The siRNAs were incubated in the RISC cleavage assay conditions with or without the target RNA (5'-capped but not radioactively labeled). The single-stranded guide siRNAs were degraded within the first 15 minutes of incubation (Fig. 4), whereas the guide strand of the siRNA duplex remained intact in the extract throughout the 2hour incubation time (Fig. 5). In both cases, stability of single- or double-stranded siRNAs was not influenced by the presence of target RNA in the cleavage assay.

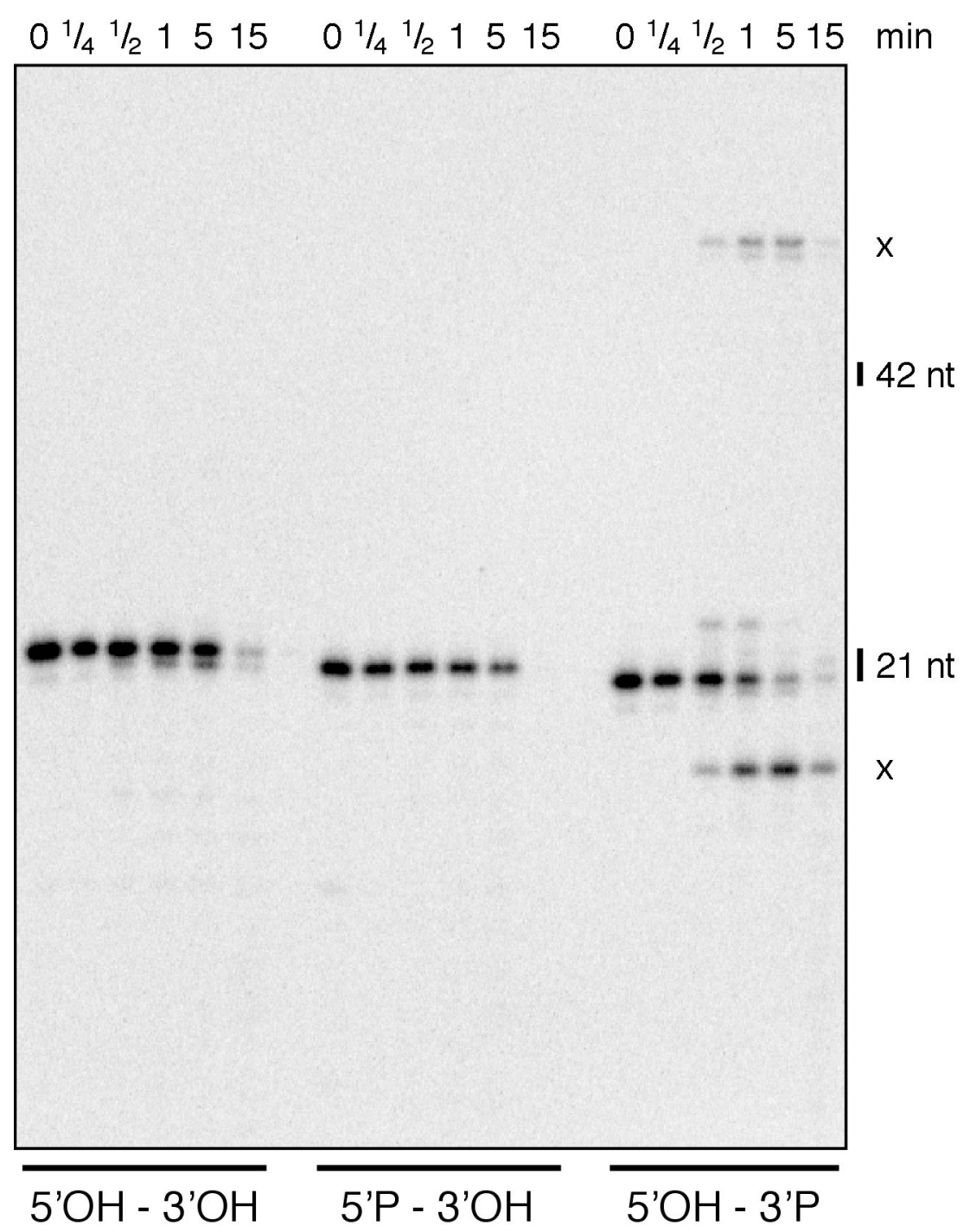

Fig. 4 Single-stranded siRNAs in the HeLa S100 extract are degraded within the first 15 min of incubation. The degradation of siRNAs was visualized on a $15 \%$ sequencing gel. ' $x$ ' marks side-products specific to the sequence of the particular RNA oligonucleotide used in the assay. 
Rapid 5'-phosphorylation of siRNA duplexes with free 5' hydroxyl termini was observed, whereas the 3'-phosphorylated siRNAs were gradually dephosphorylated at the 3' end (Fig. 5A). Eventually, all combinations of siRNA duplexes added to the extract were converted to resemble the naturally generated siRNAs, bearing 5' phosphate and 3' hydroxyl at their termini (Fig. 5B). These results were similar to the observations made for the fly embryo lysates (Nykänen et al., 2001).

No siRNA-primed polymerization products were detected, suggesting that siRNAs may not function as primers for template-dependent dsRNA synthesis in human cells. However, a small fraction of the 3'-phosphorylated antisense siRNA was ligated to the opposing 5 ' hydroxyl group of the sense siRNA producing a lower mobility band (Fig. 5A).

Both predicted $42 \mathrm{nt}$ ligation products were chemically synthesized; the product of ligation of the 3'-phosphorylated antisense strand to the 5' hydroxyl end of the sense strand (Fig. 6A, shRNA 42.A), and the product of ligation of the 3'-phosphorylated sense strand to the 5' hydroxyl end of the antisense strand (Fig. 6A, shRNA 42.B). Cleavage assays were performed with either of the two $42 \mathrm{nt}$ hairpins, side by side with the siRNA duplex. Neither of the $42 \mathrm{nt}$ hairpins was able to specifically mediate target RNA cleavage in the in vitro assay (Fig. 6C).

Fig. 5 Incubation of a duplex siRNA in the HeLa S100 extract yields the 5' phosphate and 3' hydroxyl termini.

(A) SiRNA duplexes in the HeLa S100 extract become 5'-phosphorylated and 3' dephosphorylated. The four different antisense (as) strands generated as shown on the Fig. 3B, were annealed to the complementary (sense, s) strand bearing hydroxyl termini and incubated for $15 \mathrm{~min}$ or 2 hours in the cleavage assay conditions in the presence of non-radiolabeled target RNA. Identical results were obtained when using 5'phosphorylated sense siRNA, or in the absence of target RNA during incubation. Unexpectedly, a fraction of siRNA duplexes containing 3' phosphates appeared to be subjected to a ligation reaction resulting in a $42 \mathrm{nt}$ long RNA species.

(B) Observed pathways of phosphorylation and dephosphorylation of a modified siRNA strand forming a duplex in the HeLa S100 extract. 
A
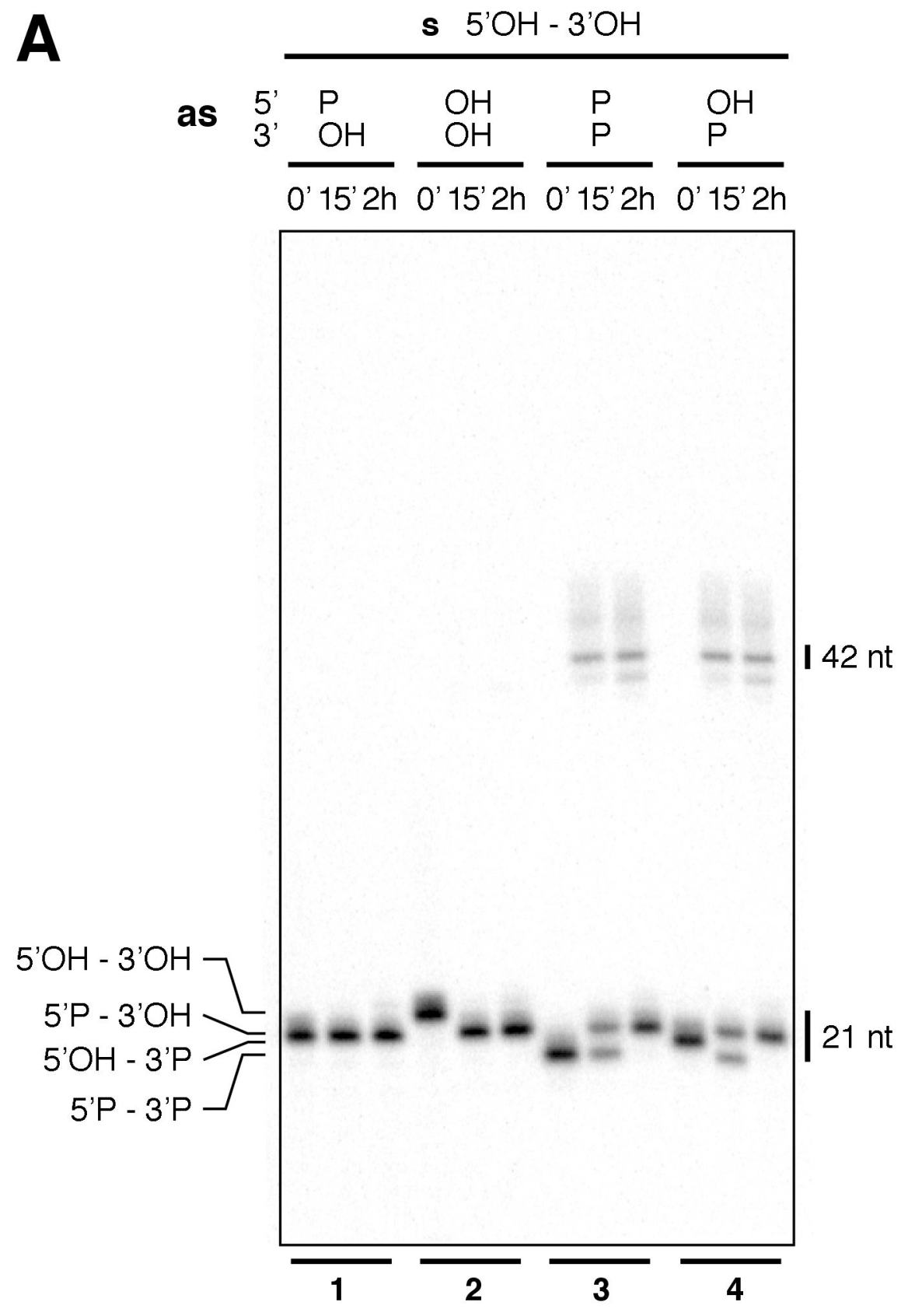

B

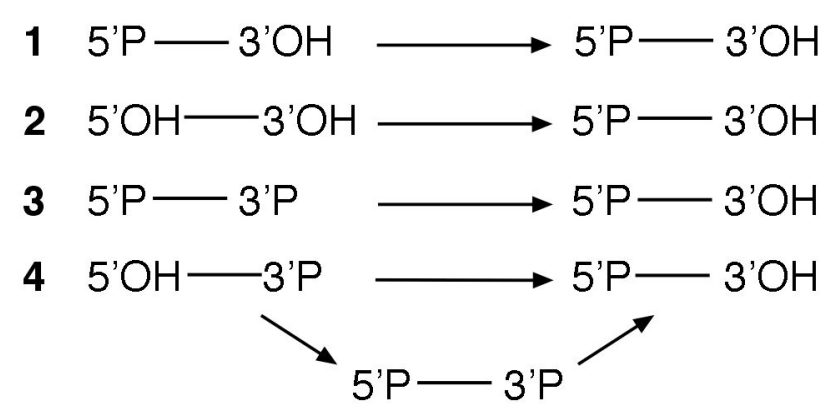




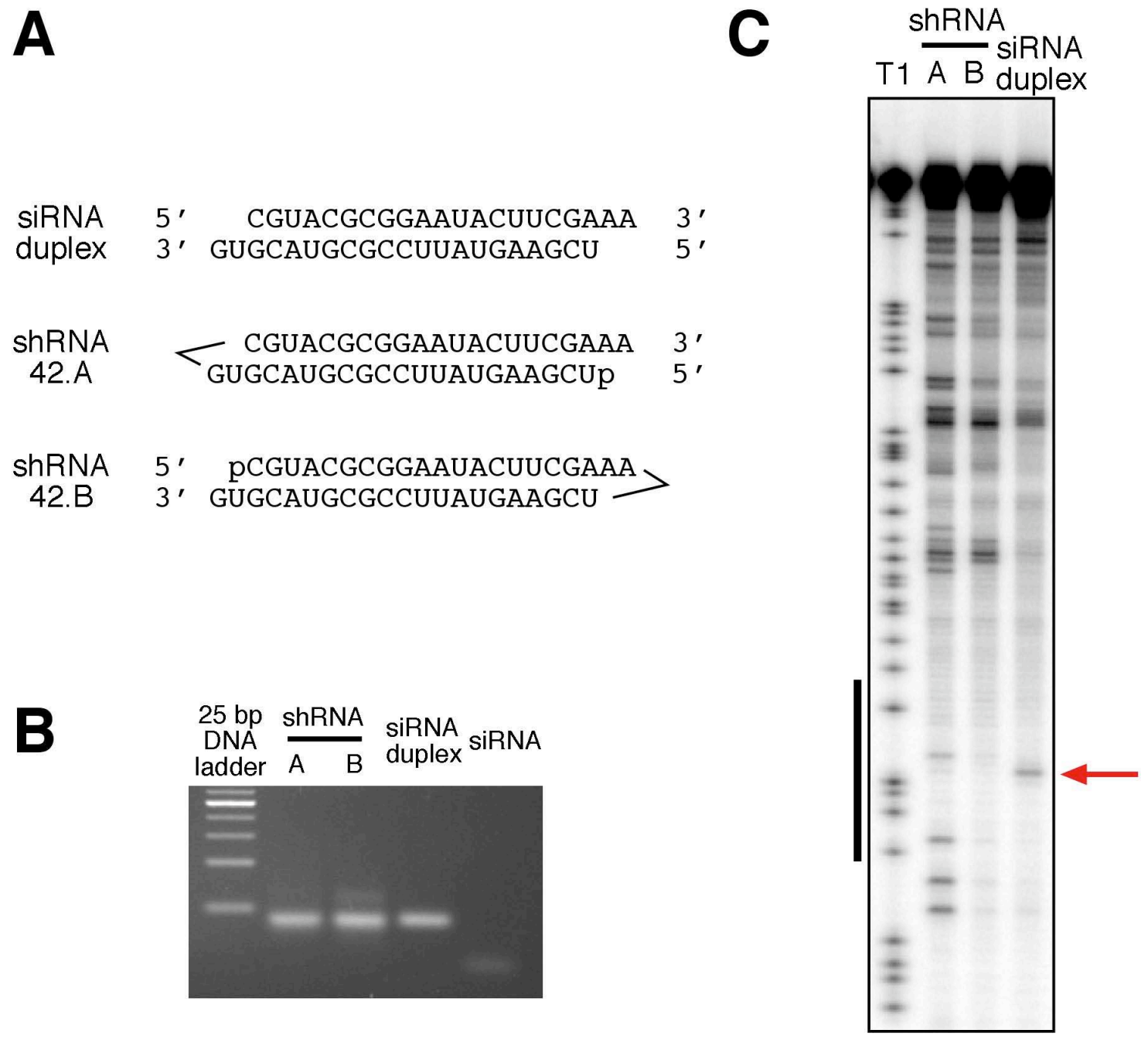

Fig. 6 The 42 nt long ligation products of unusual 5' hydroxyl and 3' phosphate termini of siRNA duplex are inactive in the target cleavage.

(A) SiRNA duplex and predicted hairpins (shRNAs) resulting from the ligation of its termini were chemically synthesized and used in the target cleavage reaction.

(B) Chemically synthesized $42 \mathrm{nt}$ shRNAs and annealed strands of the corresponding siRNA duplex have the same electrophoretic mobility, as controlled on a $4 \%$ low melting point agarose gel upon staining with ethidium bromide.

(C) The $42 \mathrm{nt}$ long shRNAs are inactive in the cleavage reaction of the cap-labeled target RNA. The black line indicates the region of the target RNA, which is complementary to the guide strand of the siRNA duplex. The red arrow marks the cleavage site. 


\subsubsection{Single-stranded siRNAs mediate RNAi in human cells}

The activity of RISC in HeLa S100 extract can be programmed by an siRNA duplex, as well as by a single-stranded siRNA, although at 100-fold higher concentration (Martinez et al., 2002). To test if single-stranded siRNAs could also trigger mRNA silencing in vivo, the RNAi experiments in the cell culture were performed.

The endogenous gene of lamin $\mathrm{A} / \mathrm{C}$ was targeted following a protocol established previously for the RNAi experiments in HeLa cells (Elbashir et al., 2001a; Elbashir et al., 2002). Single-stranded 3' hydroxyl and 5' phosphate-modified sense or antisense siRNAs, or an siRNA duplex, were lipofected into HeLa cells. Lamin A/C levels were monitored $48 \mathrm{~h}$ later using immunofluorescence microscopy (Fig. 7A), as well as quantitative luminescence-based Western blotting analysis (Fig. 7B). Both phosphorylated and nonphosphorylated single-stranded antisense siRNA appeared to reduce the protein level of the targeted lamin $\mathrm{A} / \mathrm{C}$ gene, with the phosphorylated antisense siRNA performing as efficient as the siRNA duplex. Single-stranded sense siRNA did not alter expression of the target gene levels. The levels of lamin A/C protein were normalized to the results obtained with a nonspecific GL2 siRNA duplex transfection.

It has been previously noticed, that the differences in silencing efficiencies between 20 and $25 \mathrm{nt}$ siRNA duplexes in human cell culture are not very pronounced (Elbashir et al., 2002). To assess the length requirements of single-stranded siRNAs to mediate RNAi in the cell culture, 5' hydroxyl and 5'-phosphorylated antisense siRNAs targeting lamin A/C, varying in length between 13 and 29 nt were tested. Gene silencing was observed with phosphorylated, as well as with nonphosphorylated antisense siRNAs ranging in length between 19 and $29 \mathrm{nt}$. The phosphorylated antisense siRNAs were consistently performing better than the nonphosphorylated ones, and their silencing efficiency was comparable to that of the conventional siRNA duplex of $21 \mathrm{nt}$ (Fig. 8). 
A
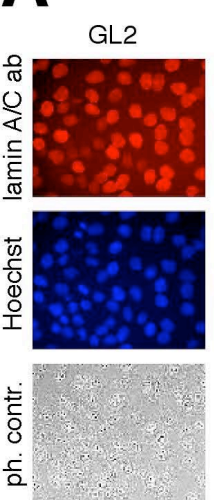

21-nt lamin A/C siRNAs (2'-TT-overhangs)

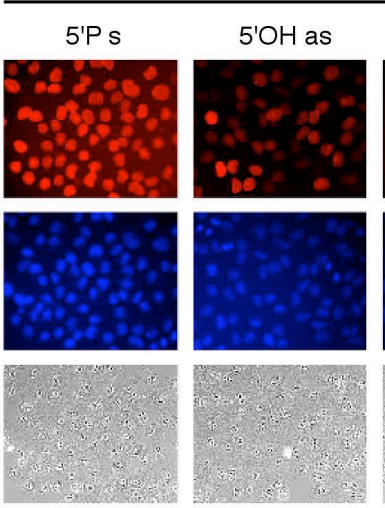

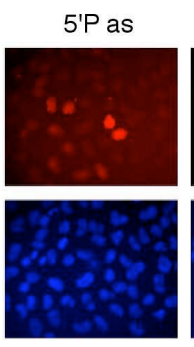
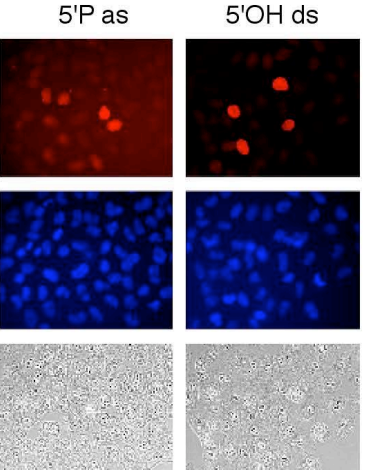

B

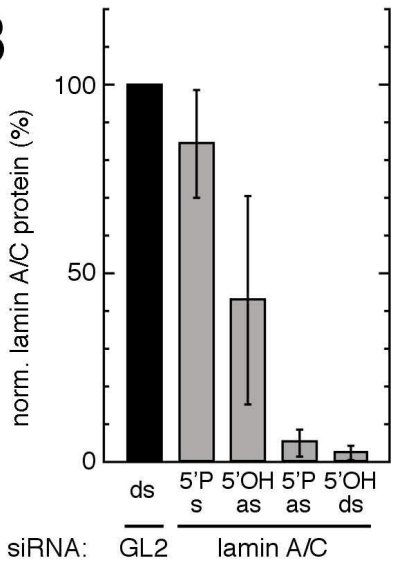

Fig. 7 Single-stranded antisense siRNAs silence endogenous gene in HeLa cells.

(A) Silencing of nuclear envelope protein lamin A/C. Fluorescence staining of HeLa SS6 cells transfected with lamin A/C-specific siRNAs and GL2 luciferase control siRNA. Top row, anti-lamin A/C staining; middle row, Hoechst chromatin staining; bottom row, phase contrast images. TT indicates deoxythymidine $2 \mathrm{nt} 3$ ' overhangs.

(B) Quantification of lamin A/C knockdown after Western blotting analysis. The blot was stripped after anti-lamin $\mathrm{A} / \mathrm{C}$ probing and re-probed with anti-vimentin antibody. Quantification was performed using Lumi-Imager (Roche) and LumiAnalyst software to quantify the ECL signals (Amersham Biosciences). Differences in gel loading were corrected relative to non-targeted vimentin protein levels. The levels of lamin A/C protein were normalized to the results obtained upon transfection with the nonspecific siRNA duplex targeting luciferase gene (GL2). 


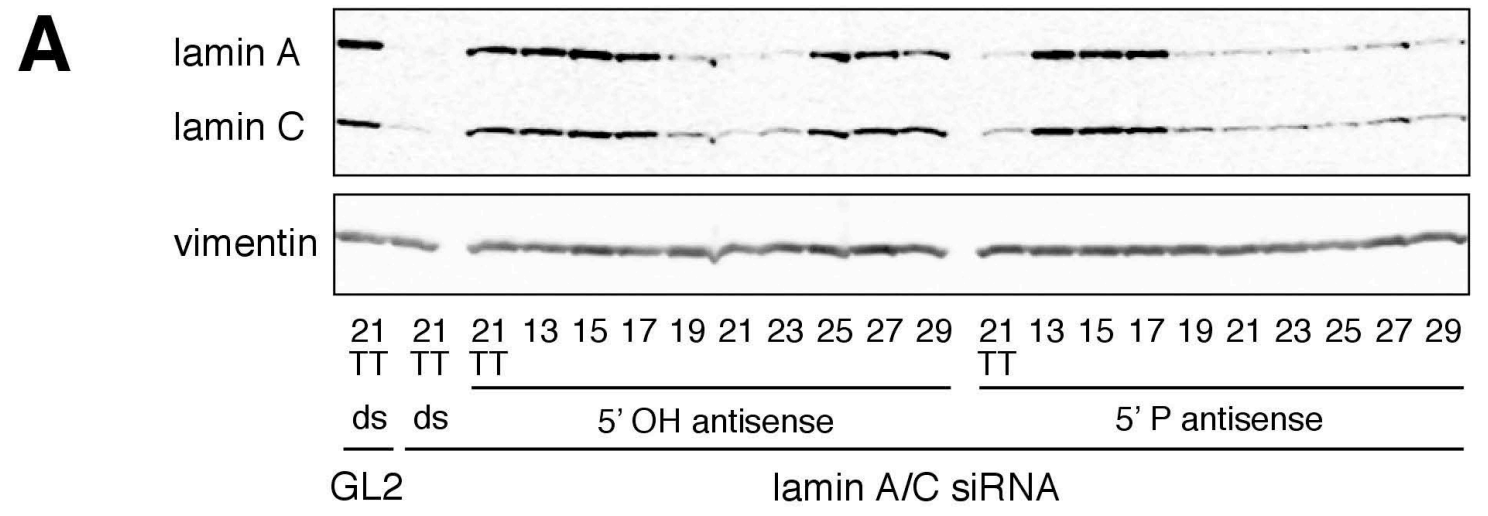

B

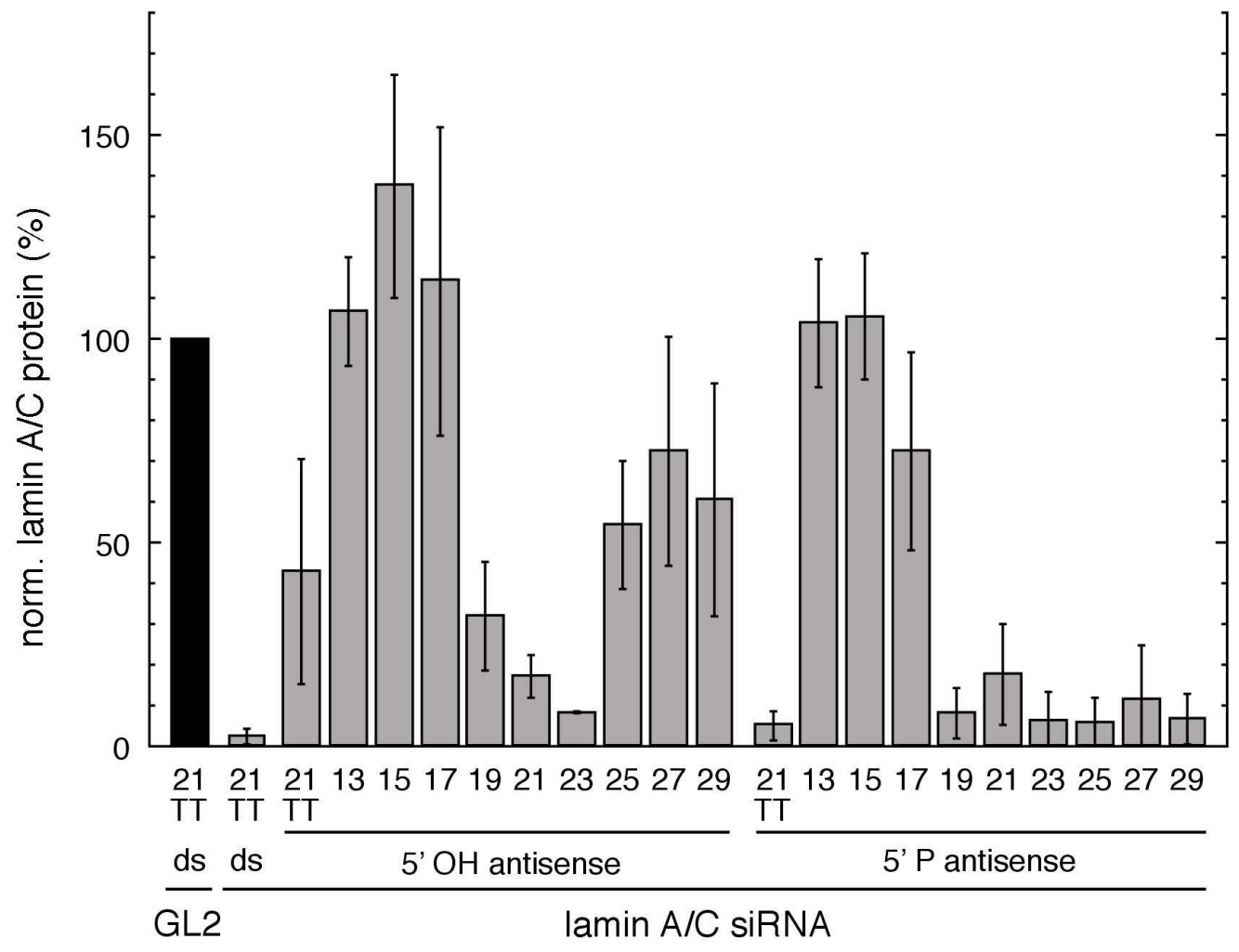

Fig. 8 Single-stranded antisense siRNAs of 19 to $29 \mathrm{nt}$ in length, both nonphosphorylated and phosphorylated, silence the endogenous gene of lamin A/C in HeLa cells.

(A) Western blotting analysis of lamin A/C knockdown, compare Fig. 7B.

(B) Quantification of the Western blotting signal, compare Fig. 7B. 


\subsection{Characterization of the human Argonaute proteins}

\subsubsection{Human genome encodes 8 Argonaute proteins}

Members of the Argonaute protein family are involved in all known RNA silencing processes. Ago1 and Ago2 purified with the catalytically active human RISC (Martinez et al., 2002), were the first proteins identified in the human RNAi effector complex. Therefore, to learn about the mechanism of RNAi in human cells, I set off to investigate the Argonautes and their role in the RNA silencing processes.

Human genome was searched in order to identify members of the Argonaute family. The sequence homology search was performed through the NCBI web server, using cDNA sequences of Ago1 (Acc. No. AF093097 (Koesters et al., 1999)) and Hiwi (Acc. No. AF264004 (Sharma et al., 2001)). Initially, six Argonaute genes were identified (Ago1 through 4, Hiwi and Hiwi2). As the annotation of the human genome progressed, two more genes (Hili and Hiwi3) were found. Three of the Ago genes, Ago4, 1 and 3 are located in a tandem arrangement on chromosome 1, while Ago2 is located on chromosome 8. This may suggest a coordinate expression of the Ago4-1-3 cluster. Other Argonaute genes are dispersed throughout the genome. The chromosomal location and the alternative names of all 8 human Argonaute genes are summarized in the table.

\begin{tabular}{|l|l|l|}
\hline gene & alternative name & chromosomal location \\
\hline Ago1 & EIF2C1 & $1 \mathrm{p} 34$ \\
Ago2 & EIF2C2 & $8 \mathrm{q} 24$ \\
Ago3 & EIF2C3 & $1 \mathrm{p} 34$ \\
Ago4 & EIF2C4 & $1 \mathrm{p} 34$ \\
\hline Hili & Piwil2 & $8 \mathrm{p} 21$ \\
Hiwi & Piwil1 & $12 \mathrm{q} 24$ \\
Hiwi2 & Piwil4 & $11 \mathrm{q} 21$ \\
Hiwi3 & Piwil3 & $22 \mathrm{q} 11$ \\
\hline
\end{tabular}

Fig. 9 Alignment of amino acid sequence of the human Argonaute family members.

PAZ domain, green frame; Piwi domain, black frame; red stars below the alignment indicate the residues of the putative catalytic 'DDH' motif. The amino acids were colorcoded as follows: in red, identical; in blue, conservative; in green, weakly similar. The alignment was generated using AlignX from the Vector NTI package (InforMax). 


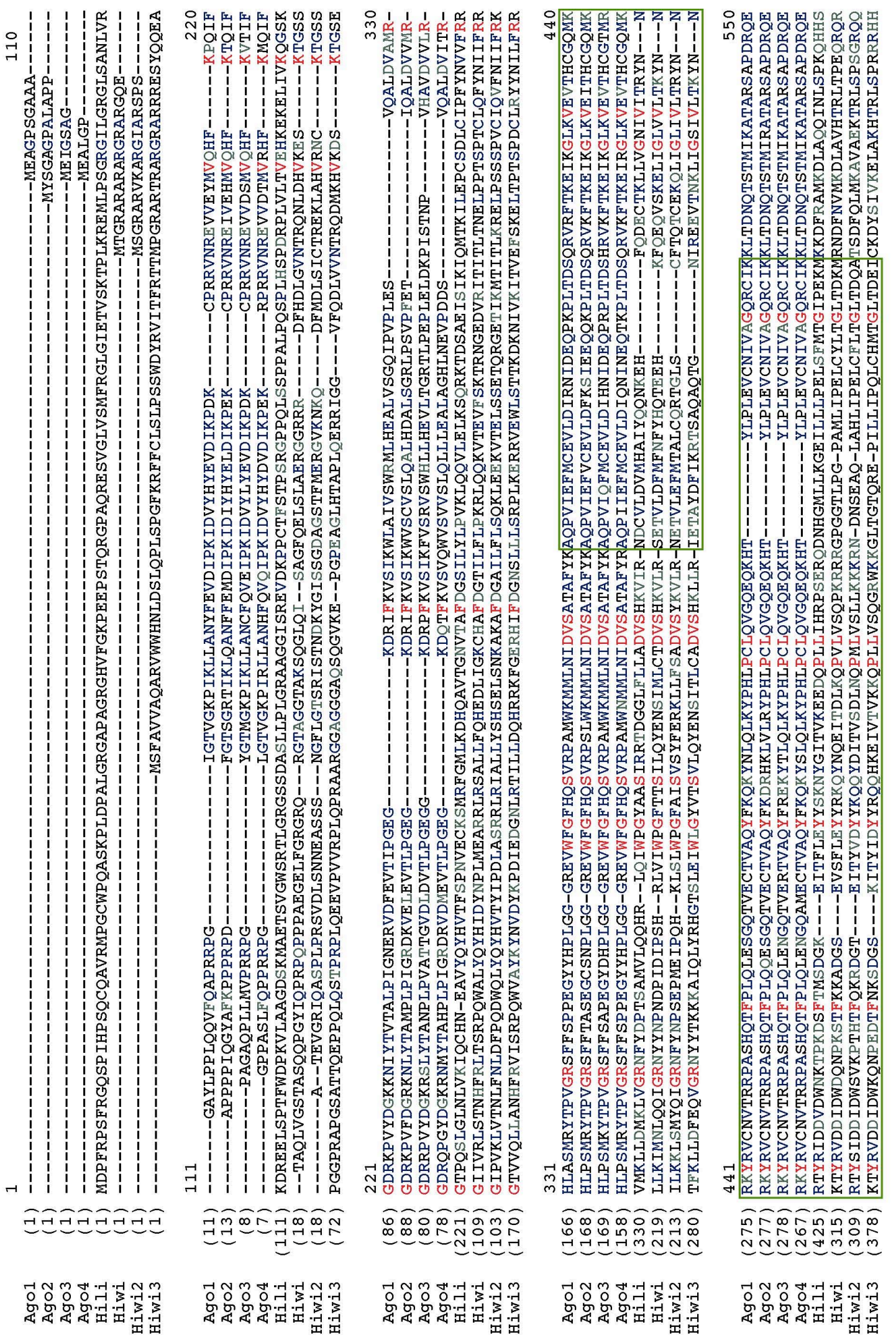




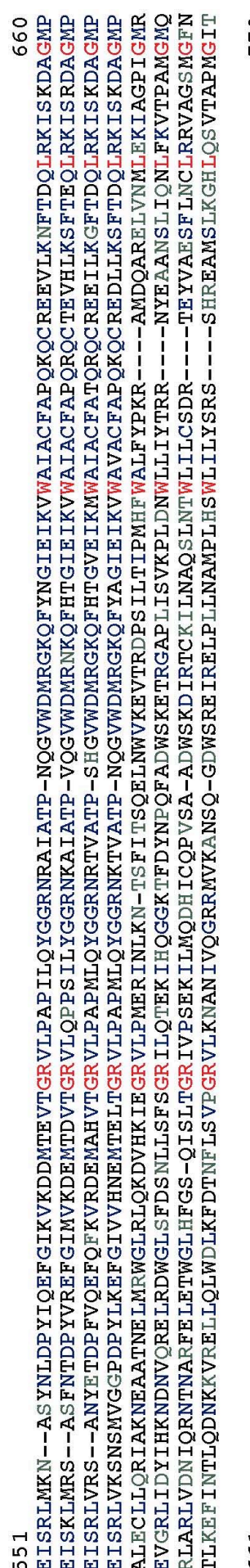

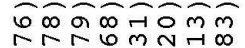

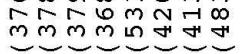

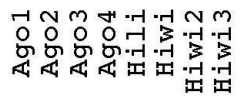

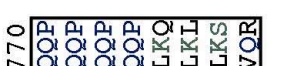

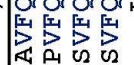

W

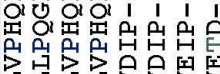

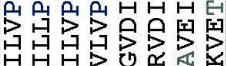

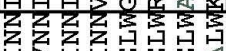

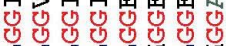

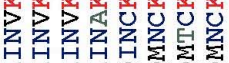

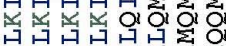

일

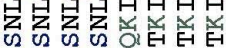

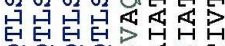

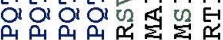

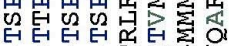

111190

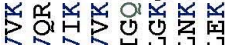

期是昆兒

o

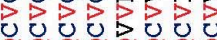

I

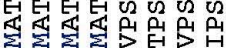

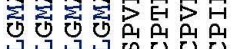

鸟年珀

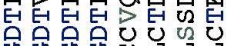

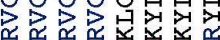

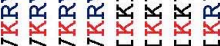

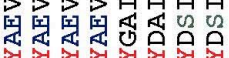

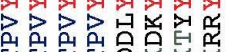

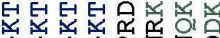

\begin{tabular}{llll}
1 & 1 & 1 & 1 \\
0 & 5 & 2 \\
\hline & 0
\end{tabular}

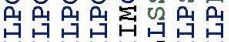

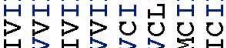

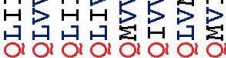

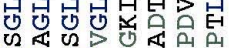

क्ष

䛼䛼䛼留

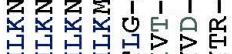

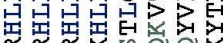

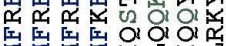

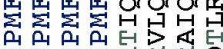

卧纴星

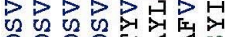

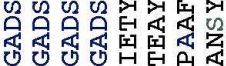

Oण

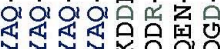

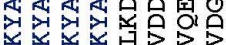

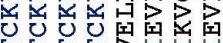

Uण

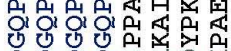

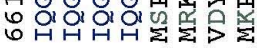

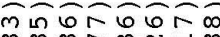

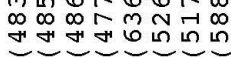

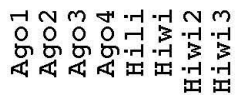

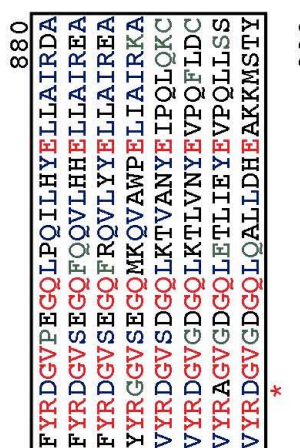

H

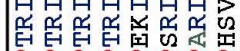

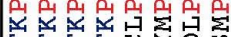

出出鱼国罗

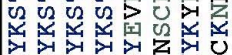

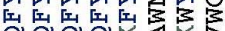

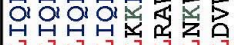

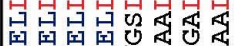

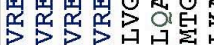

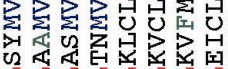

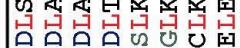

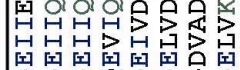

$1 \mid$\begin{tabular}{lll|l}
1 & 0 & 1 & 1 \\
1 & 0 & 1 & 1
\end{tabular}

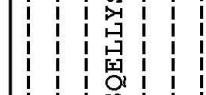

\begin{tabular}{llll|l} 
& & 0 & 1 \\
1 & & 1 & 1 \\
1 & 1 & 1 & 1
\end{tabular}

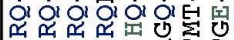

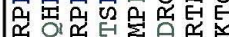

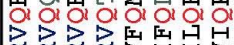

on 0 出

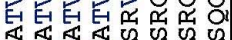

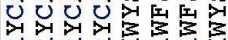

o o o w o

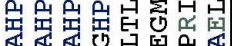

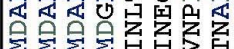

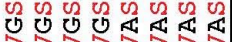

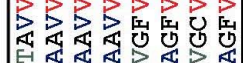

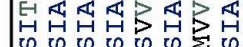

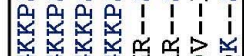

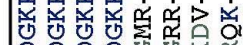

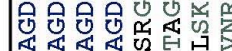

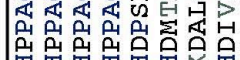

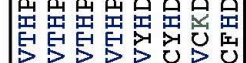

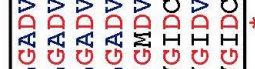

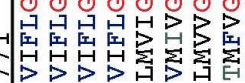

$P P P P$ 品舁

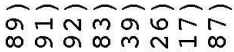

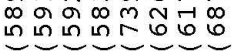

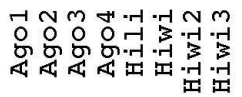

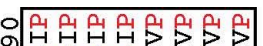

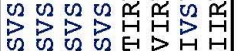

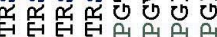

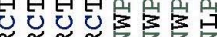

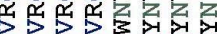

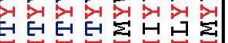

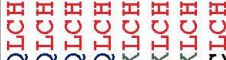

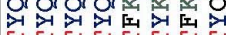

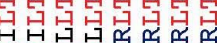

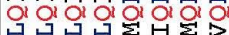

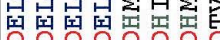

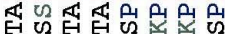

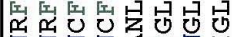

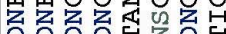
只品它品

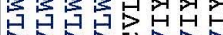

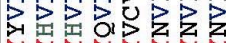

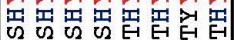

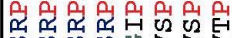

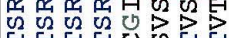
0 엉 年

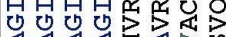
质质䍃鬼品

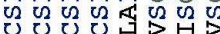

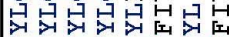

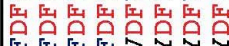

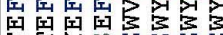

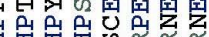

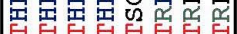

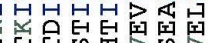

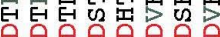

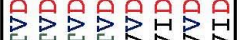

텅벙텅튕뷩벙

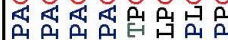

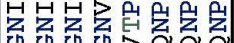
0200

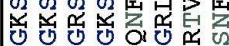

䛼留

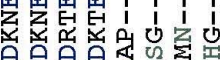

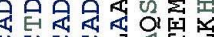

记记舁界

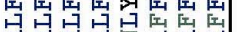
惫是罢

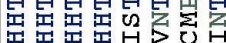

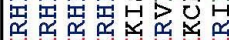
영여의

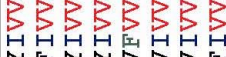

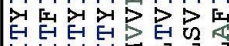

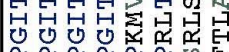
品品品员记

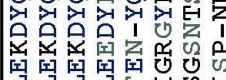
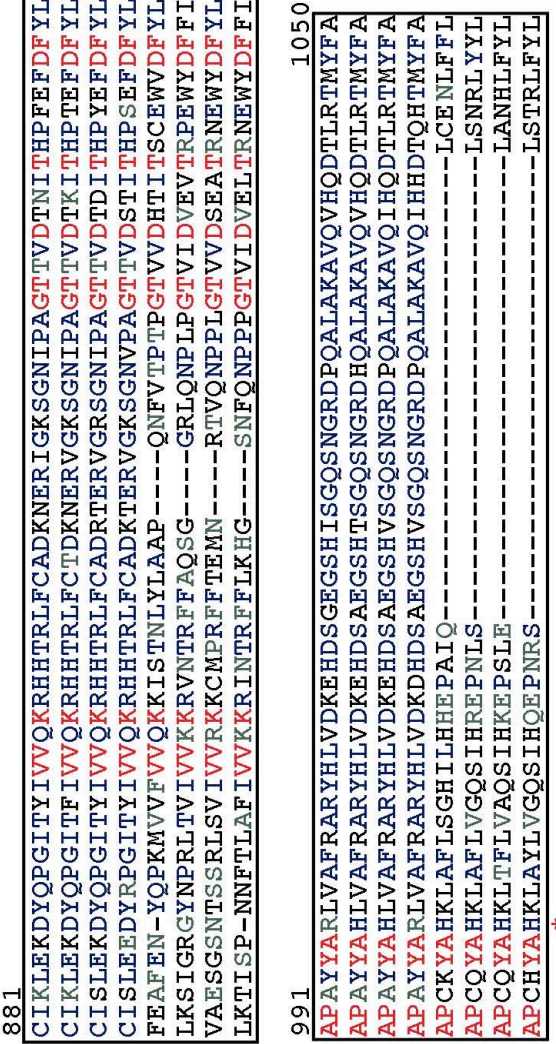

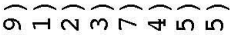

कू冋

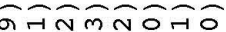

O응요

-1
0
0
0

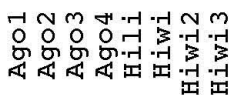


The cDNA sequences of the Argonautes were translated into protein sequences. The amino acid sequences were aligned using AlignX program from the Vector NTI package (InforMax) (Fig. 9), and the phylogenetic tree of the Argonaute family was calculated using Neighbor Joining (NJ) method from ClustalX program (Fig. 10). Argonaute proteins fell into two subfamilies, the Agos (Ago1 through 4) and the Piwis (Hili, Hiwi, Hiwi2 and 3) (Carmell et al., 2002; Sasaki et al., 2003). The Ago proteins displayed a very high homology, sharing $80 \%$ identity of the amino acid sequence. The Piwi subfamily members showed a higher sequence divergence (30-50\% amino acid identity). Protein similarity was calculated using AlignX program from the Vector NTI package (InforMax).

High sequence conservation of the Ago proteins may suggest a similar mode of action, or even their redundancy. On the other hand, the Ago and the Piwi subfamily members may have possibly diverged to play some distinct roles in the organism.

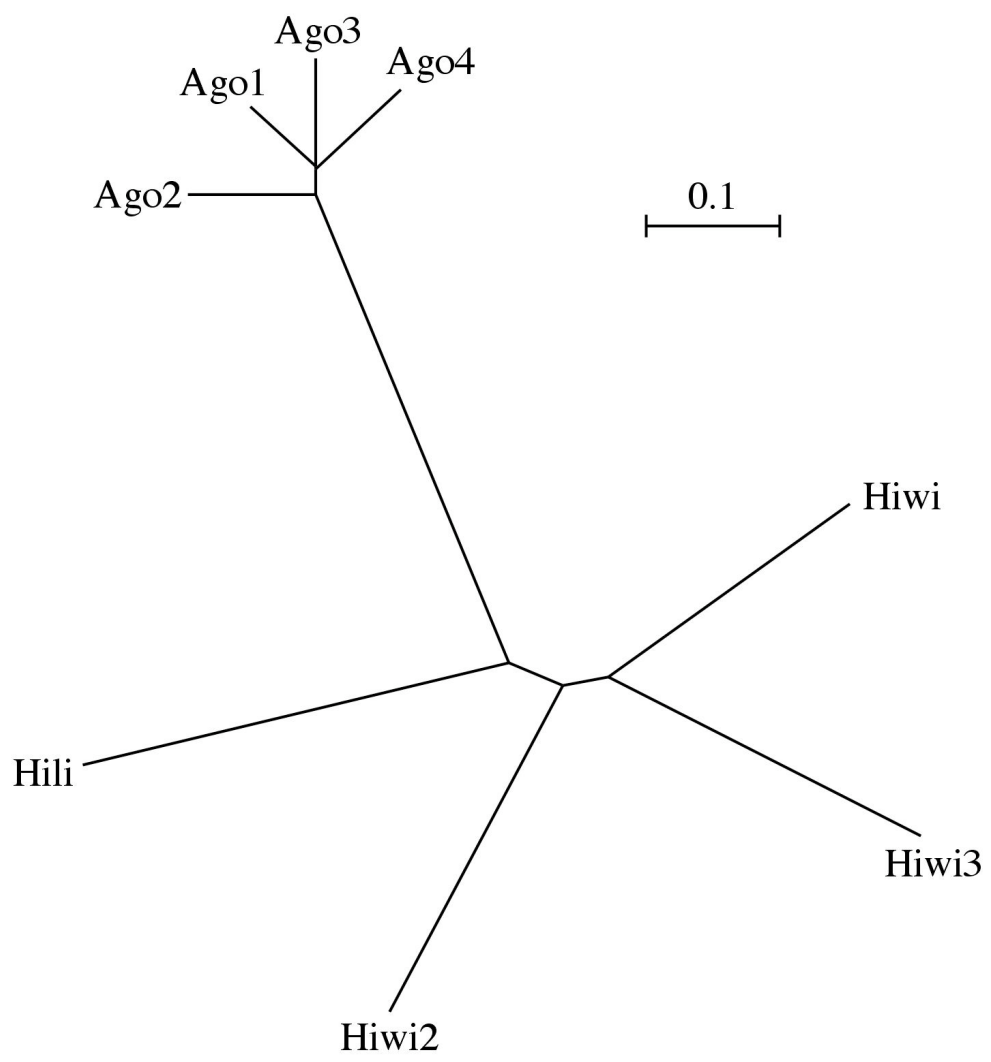

Fig. 10 Human Argonaute proteins fall into two distinct subfamilies, Agos and Piwis.

Phylogenetic tree of the human Argonaute protein family was calculated using Neighbor Joining (NJ) method from ClustalX multiple sequence alignment program. 


\subsubsection{The Agos are expressed in many cell lines}

Having in mind a biochemical characterization of RNP complexes formed by the Argonaute proteins, I aimed to identify cell lines where the Argonaute family members are endogenously expressed. If a protein of interest is expressed in the cells, it can be immunoprecipitated from the cell extract together with its interacting partners, using a specific antiserum. Alternatively, a tagged version of the protein can be introduced to the cells, and the tag-specific antibody can be utilized to isolate the protein complex. However, if the tagged protein is introduced ectopically into a cell line, its natural interactors may not be present and the artifactual complexes may form.

Expression of the Argonaute proteins has been investigated in human tissues. While the human Ago proteins are expressed ubiquitously (Koesters et al., 1999; Sasaki et al., 2003), expression of the Piwi subfamily members seems to be much more restricted. Mouse homologs of human Hiwi and Hili proteins were found expressed in the germline cells (Kuramochi-Miyagawa et al., 2001).

The expression of Argonautes was first screened on the mRNA level. The quantitative real-time RT-PCR (qRT-PCR) was used to obtain a comprehensive picture of transcript levels of all 8 human Argonaute proteins in cell lines amenable for biochemical studies. The results were normalized to GAPDH transcript levels, to allow for the comparison between the cell lines.

The screen included human cell lines derived from cervical carcinoma (HeLa S3), embryonic kidney (HEK 293), Burkitt's lymphoma (BL-41), adrenal gland small cell carcinoma (SW-13), hepatoma (Hep G2 and Huh-7.5), mammary gland adenocarcinoma (MCF-7) and brain neuroblastoma (SH-SY5Y). Additionally, in order to increase the probability of finding a suitable system to study human Piwi proteins, embryonal carcinoma (NT2/D1 and NCCIT) and normal testis-derived cell lines (Hs 1.Tes and Hs 181.Tes) were screened, and compared with the normal human ovary and testis tissue (Fig. 11).

Fig. 11 Ago subfamily genes, unlike Piwis, are transcribed in many different cell lines.

Transcript levels of the Argonautes family members were determined by qRT-PCR and are displayed in a logarithmic scale after being normalized to GAPDH mRNA level of the respective cell line or tissue. The total RNA from ovary (42 yrs.) and testis (73 yrs.) was kindly provided by Mike Brownstein, NIH. 
RESULTS

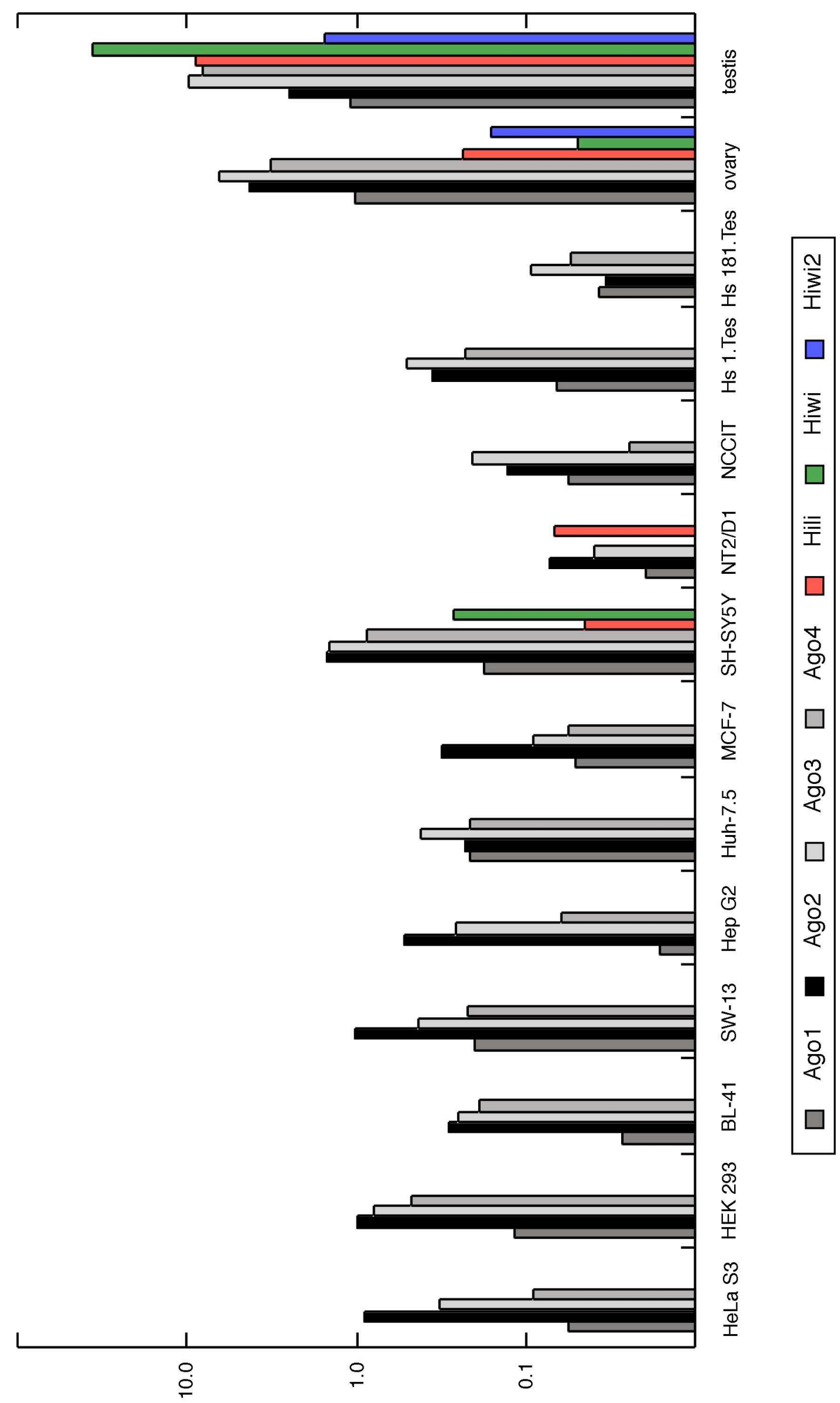

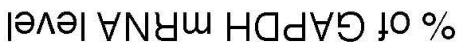


Transcripts of the four members of the Ago subfamily were detected in all tested cell lines. Ago2 and Ago3 mRNAs were generally transcribed at similar levels, while Ago1 and Ago4 varied in their transcription. The levels of Ago4, 1 and 3 transcripts were different one from another, suggesting, that these genes are not coordinately transcribed, or that their mRNAs have different turnover rate in cells. The mRNA transcript levels of the Ago members were 100- to 1000-fold lower than the GAPDH mRNA used for normalization.

Only SH-SY5Y and NT2/D1 cell lines showed Hili and/or Hiwi genes expressed. The transcript levels of the Piwi subfamily members in other cell lines were at least 10,000-fold below GAPDH, and could not be reliably quantified. Testis cell lines Hs 1.Tes and Hs 181.Tes did not express detectable amounts of Piwis, however the origin of these cell lines is not well defined, and it is not known whether they derive from the germline or rather from somatic cells in the testis.

Transcripts of the Piwis were readily detected in the tissue samples from ovaries and testes. Only Hiwi3 was at least 10,000-fold less abundant than GAPDH, and thus not quantifiable. In the testes, Hili, Hiwi and Hiwi2 displayed an expression similar to the Agos, whereas in the ovaries the same genes were expressed at a 10-fold lower level than the Ago subfamily members. 
RNAi knockdown experiments of Ago proteins were conducted in HeLa S3 cell culture. Four sets of siRNA duplexes were designed, each set specific to one of the four Ago genes. SiRNA duplexes of each set were pooled together, to increase the efficiency of the knockdown while minimizing the off-target effects, and transfected into the HeLa S3 cells. Cells were collected 24 hours post-transfection and their RNA was isolated. Levels of the Ago transcripts were analyzed by qRT-PCR and readouts of each experiment were normalized to the level of internal GAPDH transcript (Fig. 12). The results showed a specific reduction of mRNA below 10\% of the initial level for Ago1, Ago2 and Ago4, and below 25\% for Ago3, while the level of the non-targeted subfamily members did not change. These results verified the specificity of generated reagents, both of the siRNAs and the qRT-PCR primers. No significant growth inhibition or apoptosis was observed during the time of the procedure, and also upon 48-hour culture of the knockdown cells.

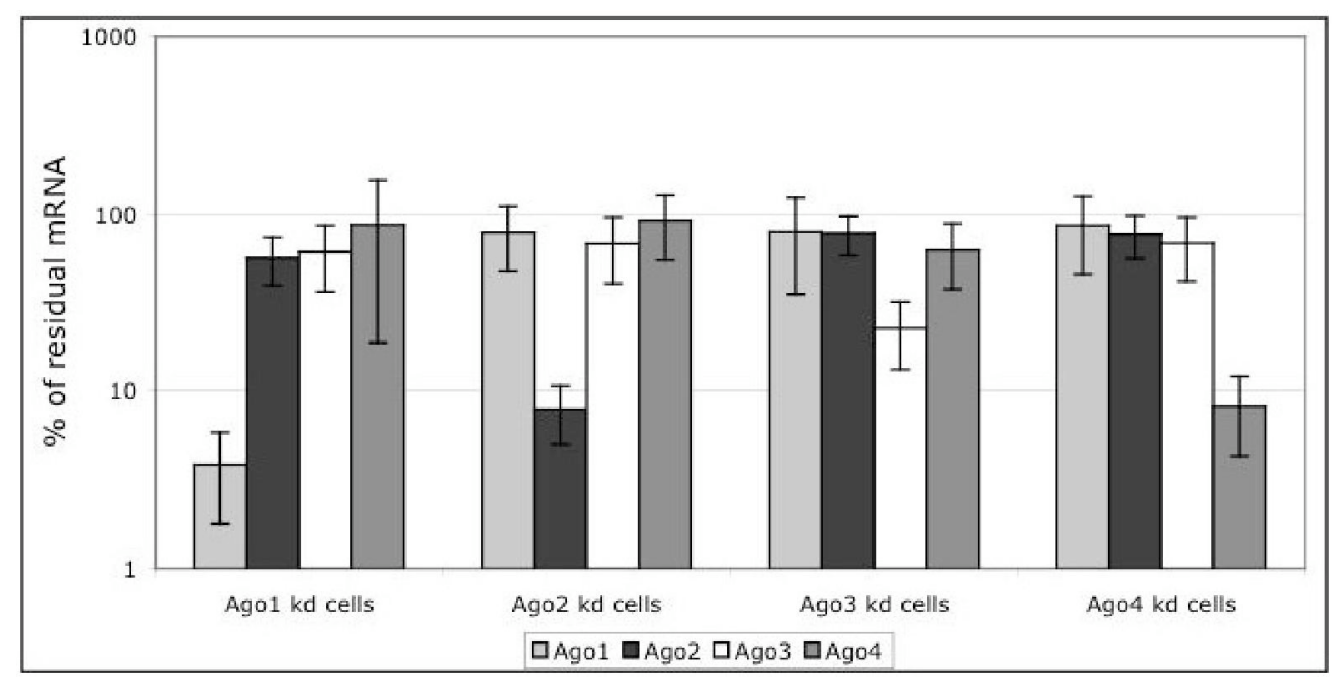

Fig. 12 Transcripts of the individual Ago genes can be specifically and efficiently depleted from HeLa S3 cells.

HeLa S3 cells were transfected with specific pools of four siRNA duplexes targeting individual Ago genes. Cells were collected 24 hours after transfection, RNA was isolated and transcript levels of the Ago subfamily members were determined by qRTPCR. Results were normalized to the level of GAPDH mRNA in each of the samples and are presented as a fraction of the level of respective transcript in non-treated cells. Results are displayed in a logarithmic scale. 


\subsection{The Agos associate with miRNAs indiscriminately of their sequence}

Human Ago2 was reported to associate with miRNAs in a larger RNP complex (Mourelatos et al., 2002). In the search for functional differences between members of the Ago subfamily I wanted to find out, whether all of them associate with miRNAs, and if so, what are their sequence preferences.

The FLAG/HA-tagged Ago proteins were expressed in a large-scale cell cultures. Ago1, 2 and 4 tagged proteins were expressed stably in HeLa S3 cells, while the tagged Ago3 was expressed transiently in HEK 293 cells. The tagged Ago RNPs were immunoprecipitated from the cytoplasmic fraction of the cells, and the RNA extracted from the complexes served as an input material for the small RNA cloning (cell culture and RNP complex isolation performed by G. Meister and G. Teng (Meister et al., 2004)). The 19 to 24 nt fraction of total RNA from HeLa S3 and HEK 293 cells, served as a reference for the small RNA cloning. The 3' and 5' adaptor oligonucleotides were sequentially ligated to the RNA preparations. The final ligation products were reverse-transcribed and PCR-amplified yielding cDNA libraries of small RNAs (Fig. 13). 
gel fractionated total RNA

or RNA extracted from protein complexes

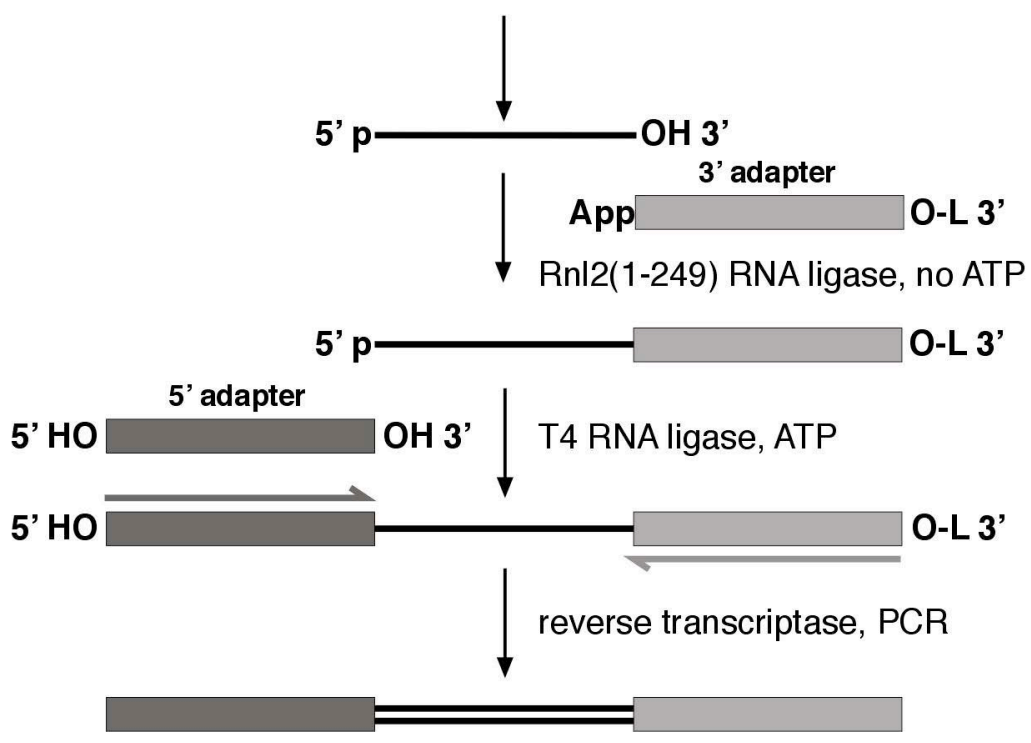

Fig. 13 Construction process of small RNA libraries.

The 3' and 5' adaptor oligonucleotides containing non-palindromic restriction site sequences were ligated sequentially to the small RNAs. The 3' adaptor was chemically adenylated on the 5' end and its 3' end was blocked. It was ligated to the small RNAs using a truncated form of T4 RNA ligase 2 (Rnl2(1-249)) that is unable to circularize RNAs containing a 5' $-\mathrm{PO}_{4}$ and 3'-OH termini. The 5' adaptor was joined to the small RNA/3' adaptor ligation product using the standard T4 RNA ligase (Rnl1). Products of the final ligation step were reverse transcribed and PCR-amplified. 
The cDNA libraries of small RNAs served as templates for semi-quantitative PCR with a forward primer specific to the 5' adaptor sequence and reverse primers specific to the 3' portion of particular miRNAs (Fig. 14A) (see Materials and Methods). In the library prepared from the total RNA of HeLa S3 cells, let-7a, miR-16, 17, 19b, 21, 24, 27a and 92 were highly abundant, while miR-25 and 32 were of low abundance, and miR-96 and 124a were not detectable (Fig. 14B). Similar miRNA profiles were obtained for the libraries prepared from FLAG/HA-tagged Ago-specific complexes, indicating that Ago1, 2 and 4 bind to miRNAs with similar affinity. In the HEK 293 library, miR-16, 17, 19b and 92 were highly abundant, while let-7a, miR-24, 25, 27a and 32 were of low abundance, and miR-21, 96 and 124a were not detectable. The miRNA profile obtained for the library prepared from FLAG/HA-tagged Ago3 using HEK 293 cells appeared similar to the total RNA-derived profile, indicating that Ago3 also binds miRNAs indiscriminately of their sequence.

These results were confirmed by performing the semi-quantitative PCR for miRNAs let-7a, mir-16, 21 and 24 using another primer design. This time, miRNAspecific primers were covering the 5' portion of the respective miRNAs, while the 3' primer was adaptor specific and invariant for all reactions (data not shown). Presented data demonstrated, that all human Ago proteins associate with miRNAs indiscriminately of their sequence. 


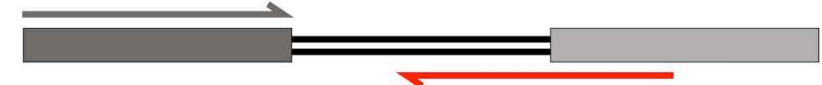

B

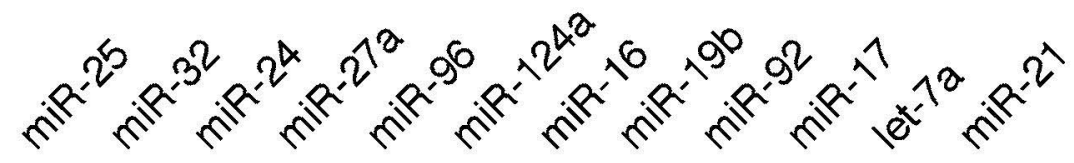

HeLa S3 tot. RNA

FLAG/HA-Ago1

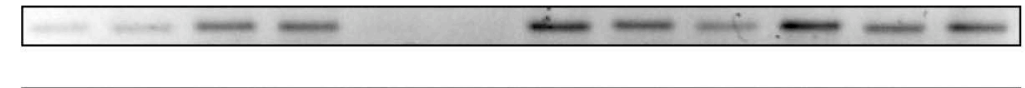

FLAG/HA-Ago2

FLAG/HA-Ago4

HEK 293 tot. RNA

FLAG/HA-Ago3

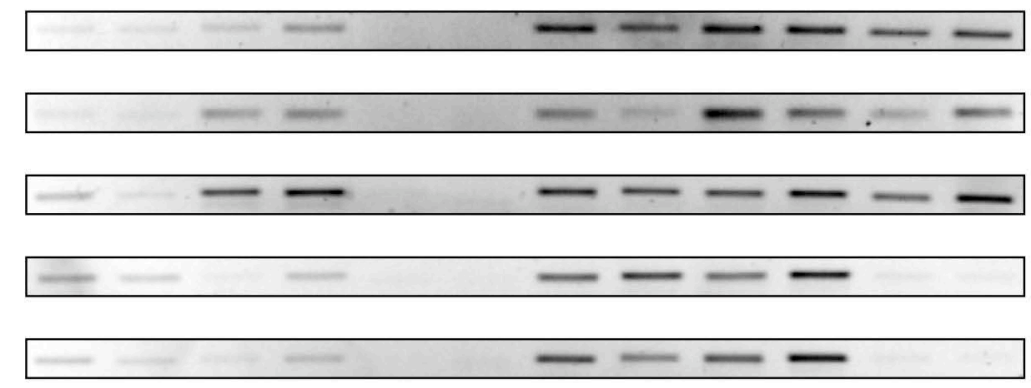

Fig. 14 MiRNAs associate with all of the FLAG/HA-tagged members of the Ago protein subfamily.

(A) Strategy of primer design for semi-quantitative PCR analysis of the relative content of miRNAs in small RNA cDNA libraries. PCR amplification was performed using a miRNA-specific 3' primer (shown in red) in combination with the invariant 5' adaptor sequence primer (shown in grey).

(B) PCR was stopped when the most abundant amplification products were still amplifying linearly. Aliquots of the PCR reaction with equal cycle numbers were separated on an agarose gel and DNA was visualized by ethidium bromide staining. The images were inverted to facilitate comparison of the bands. 


\subsection{Characterization of the human Piwi subfamily}

\subsubsection{Hiwi3 is expressed in human testis in a few splice variants}

The full-length cDNAs of Hili, Hiwi and Hiwi2 were commercially available from Mammalian Genome Collection (http://mgc.nci.nih.gov/). Hiwi3 cDNA sequence, however, was reported by only one research group (Sasaki et al., 2003).

The Hiwi3 cDNA was cloned from the Marathon human testis cDNA library (Clontech). The longest cDNA sequence (variant A) corresponds to mRNA spliced from 22 exons (Fig. 15.A), as established using BLAT genome search engine on the UCSC server (http://genome.ucsc.edu). Two alternatively spliced exons were identified, exon 1 and exon 13, which may be absent, resulting in shorter variants $\mathrm{B}$ and $\mathrm{C}$ of the Hiwi3 protein. In variant $A, A T G$ is contributed by the exon 1 . In the variant $B$, in the absence of exon 1, the translation starts with the alternative ATG located in exon 3, resulting in a $144 \mathrm{nt}$ shorter ORF (Fig. 15.B). The absence of the exon 13 in the variant $\mathrm{C}$, leads to a frame-shift and results in a premature termination codon in the exon 14 (Fig. 15.C). This may lead to either a truncated form of protein that does not have Piwi domain. Alternatively, it may result in nonsense-mediated decay (NMD) of the transcript. The previous report on cloning of Hiwi3 cDNA (Sasaki et al., 2003), described sequence of variant $\mathrm{B}$, with an additional $27 \mathrm{nt}$ insertion at the 5 ' end of exon 16 (Fig. 15.B, asterisk).

The longest variant of Hiwi3 ORF, variant A, was cloned into a mammalian expression vector pIRESneo (Invitrogen) containing an N-terminal FLAG/HA-tag. 


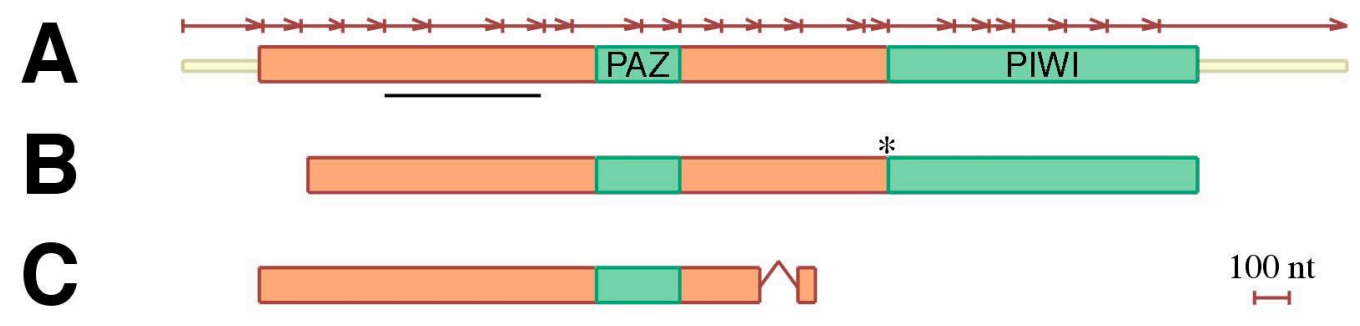

Fig. 15 Hiwi3 is expressed in a few splice variants.

(A) The longest Hiwi3 variant cloned from the Marathon human testis cDNA library. The drawing represents ORF (orange boxes) with PAZ and Piwi domains (green boxes) and UTRs (yellow lines). Arrows represent exons. Black line represents region used to produce the antigen for raising antibodies specific for all Hiwi3 variants.

(B) Shorter ORF resulting from the absence of exon 1. This variant is similar to the one described by (Sasaki et al., 2003), which includes additional $27 \mathrm{nt}$ insertion at the 5 ' end of exon 16 (asterisk).

(C) Truncated ORF resulting from the absence of exon 13, which produces a frame-shift and a premature termination codon in exon 14 .

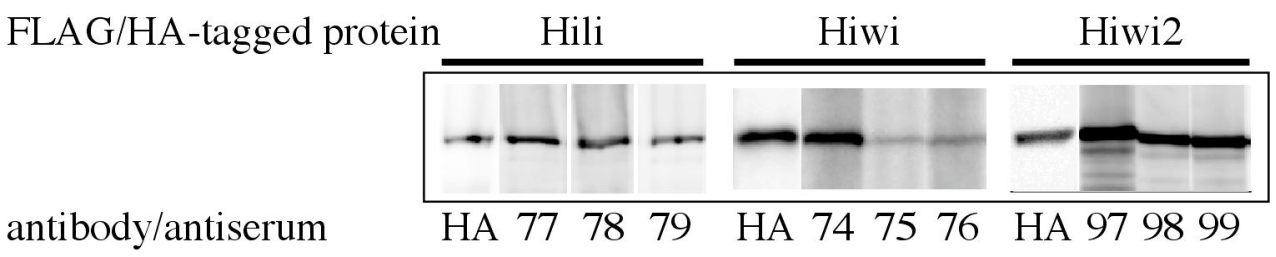

Fig. 16 Antisera generated for the Piwis recognize FLAG/HA-tagged proteins on the Western blot.

FLAG/HA-tagged Hili, Hiwi and Hiwi2 proteins were transiently over-expressed in HEK 293 cells, immunoprecipitated with the anti-FLAG antibody, resolved by the SDS-PAGE and Western blotted. Proteins were detected with a 1:100 dilution of rabbit antiserum raised against antigens prepared by G. Meister. As a positive control served the anti-HA antibody. All three antisera raised against Hiwi3 antigen were tested separately and produced similar results. 


\subsubsection{Piwi members-specific antisera detect recombinant proteins}

In order to correlate the mRNA transcription profiles obtained by qRT-PCR, with the actual protein levels of Piwis in the cell lines, the Piwi-specific polyclonal antisera were raised and characterized.

The antigen chosen to raise the Hiwi3-specific antisera, was present in all variants of the Hiwi3 protein (Fig. 15.A), and at the same time it differed significantly from other human Piwi proteins. The Hiwi3 antigen coding sequence ( $450 \mathrm{nt})$ was cloned into a bacterial expression vector with an N-terminal His-tag. The antigen was expressed in E. coli and purified on a nickel column. The antigen was sent out to Upstate Inc., where it was used to immunize 3 rabbits. The antisera specific to the Nterminal fragments of Hili, Hiwi and Hiwi2 proteins were raised by G. Meister.

The Piwi-specific antisera were tested for recognition of the recombinant Piwi proteins. FLAG/HA-tagged Piwi proteins were transiently over-expressed in the HEK 293 cells, immunoprecipitated using the anti-FLAG antibodies, separated by the SDSPAGE and Western blotted. The Western blot membranes were probed with the specific antisera. All of the tested antisera recognized the recombinant proteins on the Western blot (Fig. 16).

The Hili-specific antisera were used to probe for the expression of Hili protein in extracts of cells previously screened by qRT-PCR. Despite of a significant level of Hili mRNA in the NT2/D1 and SH-SY5Y cell lines (Fig. 11), no band of the size of Hili was detected on a Western blot by any of the Hili antisera. The antisera were subsequently IgG-purified and re-tested on the Western, but again, no specific signal was obtained. 


\subsubsection{Piwi proteins do not guide target RNA cleavage in the standard reaction conditions}

Small RNA-guided cleavage of the RNA substrate is performed only by the Ago2 RNP, but not by complexes containing Ago1, Ago3 and Ago4 (Liu et al., 2004; Meister et al., 2004). There was no data available on a catalytical activity of complexes formed by the Piwi subfamily members. Also, no other conditions of cleavage reaction have been tested so far. Interestingly, an Argonaute protein from Aquifex aeolicus, AaAgo, cleaves RNA target guided by a DNA oligonucleotide, rather than performing the RNA guided RNA cleavage (Yuan et al., 2005).

In order to screen for a cleavage activity, FLAG/HA-tagged Argonaute proteins were transiently expressed in HEK 293 cells. 48 hours after transfection cells were lysed and the tagged Argonautes were affinity purified using the anti-FLAG antibody. The expression of tagged proteins was verified by Western blotting using the anti-HA antibody (Fig. 17). Subsequently, the tagged Argonaute RNPs were programmed with an exogenous single-stranded guide against the luciferase gene, and incubated with the ${ }^{32} \mathrm{P}$-cap-labeled luciferase target RNA. The cleavage assays were performed by Y. Pei.
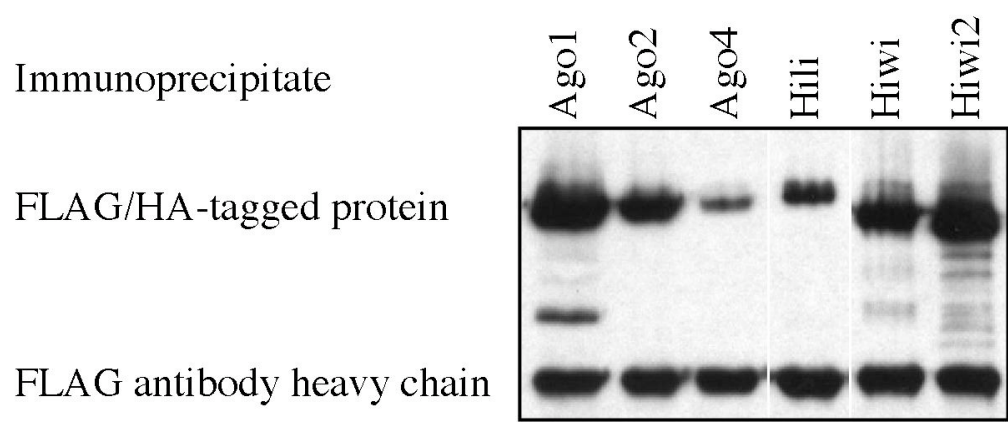

Fig. 17 Argonaute immunoprecipitates for the cleavage experiment.

FLAG/HA-tagged proteins were transiently expressed in HEK 293 cells for 48 hours and immunoprecipitated with the anti-FLAG antibody. Western blotting using anti-HA antibody served as a control for the amounts of immunoprecipitates used in the subsequent cleavage assay. Ago3 and Hiwi3 proteins were tested in a separate experiment (data not shown). 
To address the question of catalytical activity of complexes formed by the Piwi subfamily members, the standard target RNA cleavage reaction was performed. The tagged Piwi complexes were programmed with a single-stranded siRNA and incubated with the RNA target in the presence of $\mathrm{Mg}^{2+}$ (standard cleavage assay conditions). The Ago RNPs served as positive (Ago2) and negative (Ago1 and 4) controls. Apparently, none of the Piwi subfamily members performed the target cleavage, and Ago2 remained the only endonucleolytically active Argonaute protein (Fig. 18A).

In order to test whether any of the Argonautes targets RNA guided by a DNA oligonucleotide, the Argonaute complexes were programmed with a $21 \mathrm{nt}$ DNA oligonucleotide and assayed in the presence of $\mathrm{Mn}^{2+}$. The recombinant Aa-Ago protein served as a positive control. None of the Argonaute RNP complexes performed the target RNA cleavage (Fig. 18B).

Fig. 18 Ago2 is the only human Argonaute performing target RNA cleavage when guided by a single-stranded siRNA.

(A) FLAG/HA-tagged Argonaute complexes were obtained and tested by Western blotting as shown on Fig. 17. The complexes were programmed with a single-stranded siRNA and incubated with the cognate ${ }^{32} \mathrm{P}$-cap-labeled target RNA in the presence of $\mathrm{Mg}^{2+}$. Cleavage products were resolved on an $8 \%$ denaturing RNA-PAGE, and visualized by phosphoimaging. The black bar at the side of the image represents the region of the target RNA complementary to utilized guide RNA. Assay performed by Y. Pei.

(B) FLAG/HA-tagged Argonaute complexes were subjected to the procedure analogous cleavage assay, with the exception that they were programmed with DNA oligonucleotide, instead of siRNA, and the cleavage was performed in the presence of $\mathrm{Mn}^{2+}$. A purified Ago protein form Aquifex aeolicus (Aa-Ago) served as a positive control of the cleavage conditions. Assay performed by Y. Pei. 
A

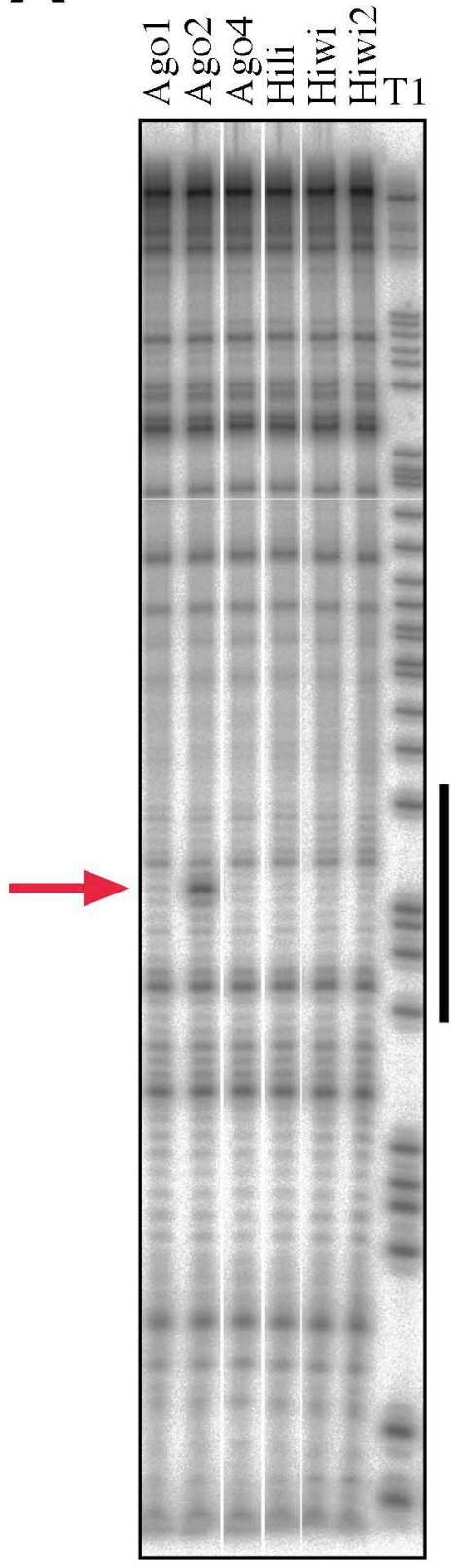

B
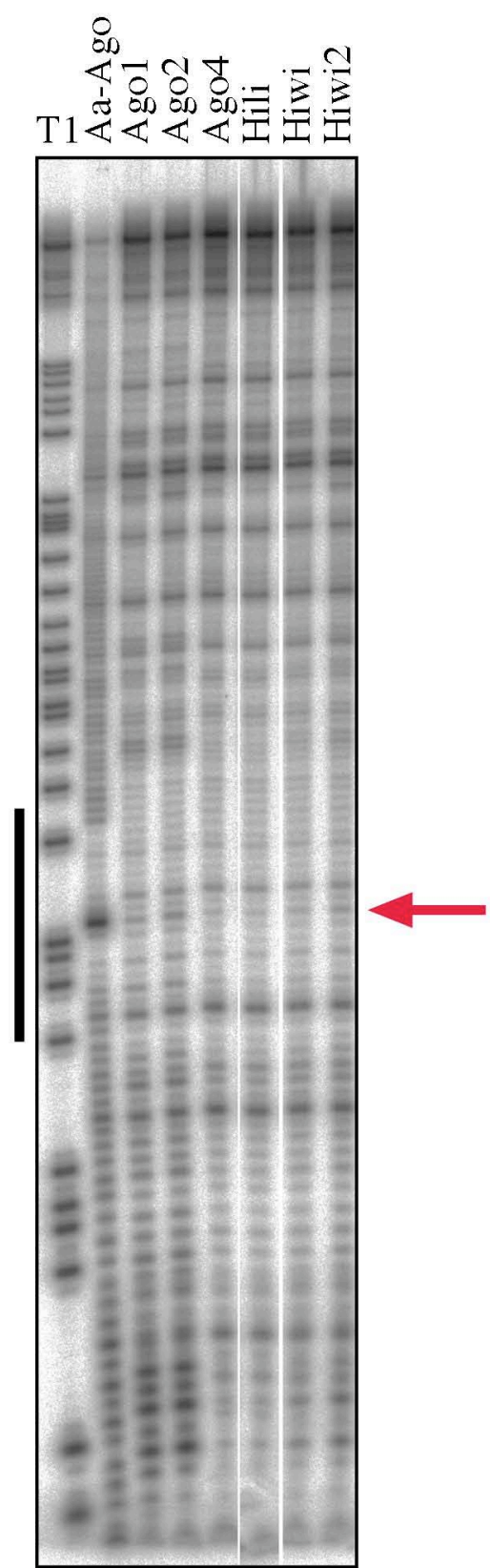


\section{DISCUSSION}

\subsection{Single- vs. double-stranded RNA trigger of RNAi}

\subsubsection{5' phosphates are maintained on an siRNA duplex}

Phosphorylation of the 5' termini of siRNA duplex in the HeLa extract is a very rapid process. Also siRNA duplexes used in human cell culture experiments are phosphorylated in the cytoplasm of the cells (Chiu and Rana, 2002). The 5'phosphorylating activity may be due to the 5' hydroxyl polyribonucleotide kinase, that otherwise may play a role in tRNA processing (Shuman and Hurwitz, 1979). However, this activity in human cells localizes to the nucleus and is otherwise poorly characterized. On the other hand, cells do not seem to posses a 3'-phosphorylating activity.

The 5' phosphate on the guide strand of siRNA duplex is essential for the target RNA cleavage in D. melanogaster (Nykänen et al., 2001). Also in the RNAi experiments in human systems, modifications of the guide strand disabling 5'phosphorylation and/or introducing additional chemical groups at the 5' terminus, render the siRNA duplex nonfunctional (Chiu and Rana, 2002; Martinez et al., 2002; Czauderna et al., 2003). These observations may be explained by fact, that the 5' phosphate of the guide strand is believed to localize in the phosphate binding pocket of the Ago2 Piwi domain (Ma et al., 2005; Parker et al., 2005). This interaction may be particularly important when the usual RISC loading pathway is circumvented by the use of a single-stranded siRNA instead of an siRNA duplex. However, recombinant human Ago2 does not require 5' phosphate to incorporate the guide siRNA, neither is it necessary for its cleavage guiding activity (Rivas et al., 2005). 5' phosphate is implicated, however, in the stability of the Ago2-siRNA complex (Rivas et al., 2005), which may be more pronounced in the cell culture or extract conditions, rather then in the purified biochemical preparations.

Lack of the 5' phosphate on the passenger strand in D. melanogaster lysate, may impair, rather than eliminate the activity of siRNA (Nykänen et al., 2001). The 5' phosphate on the passenger strand was shown to enhance binding of R2D2, a protein 
factor necessary for assembly of active RISC. In consequence, 5'-phosphorylation of the passenger strand facilitates assembly of the RISC (Tomari et al., 2004b). However, this may be simply due to the stabilizing effect of the 5' phosphate on RNA:RNA helices (Freier et al., 1983), as R2D2 was shown to bind the more thermodynamically stable end of the duplex (Tomari et al., 2004b).

\subsubsection{Synthetic siRNAs undergo ligation but not extension}

RdRP activity is required in RNA silencing processes in many organisms (see Introduction). Two kinds of RdRP activities can be distinguished, depending on the requirement of primer for the polymerization activity. An siRNA-primed RdRP activity was once implicated in the RNAi in D. melanogaster (Lipardi et al., 2001), although this finding has been disputed (Martinez et al., 2002; Schwarz et al., 2002). An RdRP homolog has not been identified by sequence homology neither in the fly nor in the human genome.

I was unable to detect the extension of labeled siRNAs in the HeLa S100 extract. The 3' hydroxyl group on the guide strand of siRNA duplex would be required for the siRNA-primed RdRP activity. However, the introduction of an aminolinker at the 3' end of any strand of the siRNA duplex did not compromise its function in HeLa extract (Martinez et al., 2002). Also, it has been demonstrated that siRNAs with blocked 3' hydroxyl groups are still functional in the human cell culture experiments (Chiu and Rana, 2002; Holen et al., 2002; Czauderna et al., 2003). This argues against the role of siRNA-primed RdRP in the RNAi process in human. Moreover, it has been demonstrated, that it is possible to specifically target one isoform or alternatively spliced variant of a message at a time, which again argues against the involvement of the RdRP activity in the RNAi process in human.

Surprisingly, I observed an activity ligating an unusual combination of 3'phosphorylated with 5 ' hydroxyl termini of the opposing strands in the siRNA duplex. Such an RNA ligase activity was previously observed in HeLa cell extract and is mediated by two enzymatic activities (Filipowicz et al., 1983). The 3' terminal phosphate is first converted to a 2',3'-cyclic phosphate by RNA cyclase in the presence of ATP (Filipowicz et al., 1985). Thereafter, the opposing 5' hydroxyl is ligated to the cyclic phosphate end by an RNA ligase, possibly a tRNA ligase, in a reaction requiring ATP (Filipowicz and Shatkin, 1983; Perkins et al., 1985). 


\subsubsection{Single-stranded siRNA mediates RNAi in human cell culture}

RNAi in human cell culture can be mediated not only by an siRNA duplex, but also by a single-stranded siRNA. Although there are some reports describing application of the single-stranded siRNA to silence genes in the cell culture (Amarzguioui et al., 2003; Randall et al., 2003; Rapozzi and Xodo, 2004), the method was not robust enough for a general application. On average, single-stranded siRNAs have to be used in many-fold higher concentrations to reach the silencing efficiency of their duplexed counterparts (Chiu and Rana, 2003; Holen et al., 2003; Xu et al., 2004).

The low silencing efficiency may be due to the rapid degradation of a singlestranded siRNA in the cells, as it happened in the cell extract. However, analysis of chemically modified siRNAs demonstrated, that even increased stability of singlestranded siRNAs did not render them efficient triggers of RNAi. This result indicated, that cellular persistence might not be the main reason for single-stranded siRNAs having lower RNAi efficacy than siRNA duplexes (Chiu and Rana, 2003; Xu et al., 2004).

Although active RISC contains a single-stranded RNA (Martinez et al., 2002; Schwarz et al., 2002; Rivas et al., 2005), efficient loading of the RISC may favor an RNA duplex. It is consistent with the presence of the dsRNA binding proteins Dicer and TRBP in the RLC (Chendrimada et al., 2005; Gregory et al., 2005; Haase et al., 2005). Thus, the inefficient process of RISC loading with a single-stranded RNA may be competed off by the RNA degradation. Consistently, single-stranded siRNAs are generally inefficient triggers of target RNA cleavage in the HeLa S100 extract (Martinez et al., 2002; Schwarz et al., 2002).

The unusual efficiency of some single-stranded siRNAs may be due to factors such as the secondary structure. Both, the lamin A/C siRNA duplex and the antisense strand, that I used in the cell culture experiments, appeared to be highly efficient and function well even at extremely low concentration (Harborth et al., 2003). It may be possible, that this siRNA formed an imperfect duplex with itself (as exemplified below), mimicking an siRNA duplex during the experimental procedure.

\footnotetext{
UGUUCUUCUGGAAGUCCAGUU

|| ||||$\cdots|||| \mid$ UUGACCUGAAGGUCUUCUUGU
}

Example of lamin A/C siRNA pseudo-duplex composed of two antisense siRNA strands. 


\subsection{Characterization of the human Argonaute protein family}

\subsubsection{The Agos are ubiquitously expressed and associate with miRNAs indiscriminately of their sequence}

The four members of the human Ago subfamily are ubiquitously transcribed in various human cell lines. In some cells, however, the transcript levels of particular Agos differ more than 50-fold, as demonstrated by the qRT-PCR. Agos are transcribed in many different, if not all human tissues, although at various levels (Sasaki et al., 2003). Moreover, during the organogenesis, Ago transcripts display differential localization in the mouse embryo, as visualized by in situ hybridization (Lu et al., 2005). The differential distribution of mRNA transcripts is likely to be reflected in the expression of Agos on the protein level.

All human Agos bind miRNAs and siRNAs, and the binding occurs independently of the small RNA sequence (Liu et al., 2004; Meister et al., 2004). However, only Ago2 is competent of miRNA-guided target RNA cleavage, and only in a presence of a highly complementary target (Liu et al., 2004; Meister et al., 2004). In the animals, however, the majority of miRNAs form bulges with their targets. In the presence of bulges, Ago2, similarly to the other Agos, is believed to mediate translational repression. Thus, the miRNA- and Ago-mediated regulation of gene expression is based mostly on the translational repression, rather than target mRNA cleavage (Bartel, 2004).

\subsubsection{Expression of the Piwis may be largely germline specific}

Since mouse Piwis are abundant in the male germline, the intention was to look for their expression in spermatogonia-derived (embryonal carcinoma) and spermatocyte-derived (seminoma) cells, where expression of Mili and Miwi, respectively, was previously reported (Fig. 2). The seminoma cell lines, however, appeared to be impossible to maintain in the culture (Raju Chaganti, MSKCC, personal communication), and thus were not tested.

Although the Hili mRNA was detected in one of the screened embryonal 
carcinoma cell lines, the endogenous protein was expressed below the detection limit of Hili-specific antibodies. The future screen for the expression of Hili should include some more cell lines of the embryonal carcinoma origin.

Hiwi mRNA was also reported in the CD34+ hematopoietic progenitor cells, although no protein expression data was demonstrated (Sharma et al., 2001). CD34+ cells can be isolated from bone marrow, peripheral blood or cord blood. Since they are impossible to maintain in the culture in an undifferentiated state, it would be interesting to check some of the CD34+ leukemic cell lines for the expression of Hiwi.

To gain the full picture of the Piwi protein subfamily, the future work could be conducted on the human testis specimens and/or lysates. This should be largely facilitated by the array of reagents, including specific antibodies that I contributed to. They will enable detection of the proteins in the cell lysates and analysis of the complexes formed by the Piwis.

\subsubsection{Piwis are not catalytically active}

All of the human Piwi proteins have the amino acid residues necessary for the target cleavage activity of Ago2 (DDH motif (Rivas et al., 2005)) (Fig. 9). Since no cell culture system naturally expressing Piwi proteins was available, to test for the potential catalytic properties, the Piwis were ectopically over-expressed in HEK 293 cells. No endonucleolytic activity of the Piwi proteins has been noticed. This approach, however, may yield false negative results, if some other protein factors necessary for the natural function of Piwis are absent from the HEK 293 cells, where Piwis are not endogenously expressed. Most probably, however, Piwi proteins act via a mechanism different than RNA cleavage, and their role in the RNA silencing processes is yet to be discovered.

It remains to be tested, whether Piwis associate with any small RNAs to begin with. It could be miRNAs, but it might be other small RNAs or DNAs as well. MiRNAs are the only endogenous small RNAs currently known in mammalian cells. However, rasiRNAs, 27 nt long small RNAs which are present in fly, might have until now escaped the discovery in mammals, as the small RNA cloning efforts concentrate on the RNA species of 19-24 nt in length. The mode of action of these RNAs in the fly is not clear.

D. melanogaster Piwi protein is involved in the GSC self-renewal (Cox et al., 
1998). Consistently, murine Mili is expressed in GSC progenitor cells of both sexes, and in the male GSCs (Kuramochi-Miyagawa et al., 2004). However, female Mili-null mouse is phenotypically normal and fertile. Also, the proliferation and differentiation of spermatogonia seems to proceed normally in the absence of Mili, and the spermatogenesis is arrested only in the prophase of the first meiotic division. It is conceivable that Mili plays an important role in meiotic prophase progression. Nevertheless, the Mili knockout mice appear to have fully functional GSCs.

Another fly Piwi subfamily protein, Aubergine, is implicated in the translational regulation of a subset of germline transcripts in the oocytes (see Introduction). Aub protein, in contrast to nucleoplasmic Piwi, localizes in the cytoplasm, together with Vasa helicase. Both, Mili and Miwi proteins are shown by the immunofluorescence microscopy to localize in the cytoplasm (Kuramochi-Miyagawa et al., 2001). Moreover, Mili and Miwi co-localize and co-precipitate with Mvh, the murine homolog of Vasa (Kuramochi-Miyagawa et al., 2004). Vasa is a marker of the nuage, which is implicated in translational regulation (Parvinen, 2005). Interestingly, Miwi was demonstrated to bind and stabilize mRNA transcripts of proteins regulating the process of spermiogenesis (Deng and Lin, 2002).

In spermatogenesis, expression of Miwi coincides with the meiotic division (Deng and Lin, 2002). As Miwi was reported to be absent from the ovaries, it suggests its involvement in a spermatogenesis-specific process, which may be for example chromatin remodeling, which starts during meiosis in males.

The precise expression pattern, cellular localization and function of the remaining Piwi subfamily proteins is unknown. Hiwi2 has his murine homolog Miwi2, and a homolog of Hiwi3 is absent from human.

\subsection{Advances in the mechanism of RNAi in human}

\subsubsection{Posttranscriptional gene silencing by RNAi}

The mechanisms by which RNA silencing complexes can repress targets in the absence of substrate cleavage are rapidly advancing.

Early reports indicated that repression by animal miRNAs occurred without changes in the overall level of the mRNA target (Lee et al., 1993; Wightman et al., 
1993). However, more recent studies demonstrate changes in the abundance of mRNAs containing partial miRNA complementary sites (Bagga et al., 2005; Krutzfeldt et al., 2005; Lim et al., 2005). These observations raise the possibility, that regulation at the level of mRNA stability may be more common than previously appreciated for the miRNA pathway.

Several studies have detected protein components of the RISC, miRNAs and some mRNA targets on polysomes, indicating that suppression might occur either during the protein synthesis (initiation or elongation step), or post-translationally, by destabilizing nascent proteins (Olsen and Ambros, 1999; Ishizuka et al., 2002; Djikeng et al., 2003; Kim et al., 2004; Nelson et al., 2004; Pham et al., 2004).

A recent study in the human cell culture system demonstrated, that Ago2 engineered to associate with an mRNA transcript represses its translation (Pillai et al., 2004). Ago2 and miRNA-dependent repression of mRNA was proposed to occur in an $\mathrm{m}^{7} \mathrm{G}$-cap dependent manner at the initiation step of translation (Humphreys et al., 2005; Pillai et al., 2005). Interestingly, Ago2 was discovered as a regulator of translation initiation (Roy et al., 1988; Zou et al., 1998).

Recent observations have also led to an alternative model for silencing by miRNAs, wherein RISC might sequester targeted mRNAs in P-bodies, cytoplasmic loci implicated in storage, processing and degradation of mRNA transcripts (Sheth and Parker, 2003; Teixeira et al., 2005; Wilczynska et al., 2005). Not only are Ago proteins found enriched in P-bodies, but mRNA targets of miRNAs become similarly localized in a manner that depends both on the presence of the miRNAs and on miRNA binding sites in the target (Liu et al., 2005b; Pillai et al., 2005; Sen and Blau, 2005). Such localization could cause repression by itself, or could occur as a downstream consequence of translational repression by RISC.

\subsubsection{Transcriptional gene silencing by RNAi}

In $S$. pombe, a single Ago protein is implicated in the posttranscriptional silencing and heterochromatin maintenance, being a component of a RISC and RITS complexes, respectively (Sigova et al., 2004). The existence of multiprotein families of Argonautes in higher organisms would suggest specialization of particular family members. In the fly, however, Ago2 which is required for RNAi (Okamura et al., 2004), is also required early in embryogenesis for the assembly of centromeric 
heterochromatin, nuclear division, nuclear migration and germ-cell formation (Deshpande et al., 2005).

It is interesting to speculate about the involvement of RNA silencing in the chromatin control in mammalian systems, as this has been best described in fission yeast. RNAi-mediated chromatin and DNA modifications play important roles in genome stability by inhibiting undesired recombination and mobilization of repetitive DNA elements such as retrotransposons. RNAi-mediated heterochromatin formation is also required for proper chromosome segregation as structural components of heterochromatin recruit the cohesin complex and promote sister chromatid cohesion at pericentromeric regions.

Nevertheless, until now no rasiRNAs have been found in mammals. It would be interesting though, to clone fractions of small RNAs $\sim 27 \mathrm{nt}$. There are, however, a few indications about involvement of RNA silencing pathways in vertebrate systems, as rasiRNAs were cloned from fish (Chen et al., 2005) and Dicer was implicated in the formation of centromeric heterochromatin in cultured vertebrate cells (Fukagawa et al., 2004; Kanellopoulou et al., 2005).

\subsubsection{Outlook}

RNAi emerged as a potent tool of gene silencing (Elbashir et al., 2001a), with broad applications in functional genomics and potentially in therapeutics (reviewed by (Dorsett and Tuschl, 2004)). Five years later, RNAi and other RNA silencing processes are much broadly appreciated for their biological significance. This, in turn, is mostly due to the miRNAs, which are predicted to regulate as many as one-third of human genes (Lewis et al., 2005), being essential for the processes such as animal development (reviewed by (Wienholds and Plasterk, 2005)). Misexpression of miRNAs is also demonstrated in human cancer (reviewed by (Caldas and Brenton, 2005)). Further elucidation of the RNA silencing mechanisms and validation of the miRNA targets are necessary to better understand the regulatory networks mediated by small RNAs and their role in human disease. 


\section{REFERENCES}

Alberts, B., Johnson, A., Lewis, J., Raff, M., Roberts, K., and Walter, P. (2002). Molecular Biology of the Cell, 4th edn (New York, Garland Publishing).

Amarzguioui, M., Holen, T., Babaie, E., and Prydz, H. (2003). Tolerance for mutations and chemical modifications in a siRNA. Nucleic Acids Res 31, 589-595.

Aravin, A. A., Klenov, M. S., Vagin, V. V., Bantignies, F., Cavalli, G., and Gvozdev, V. A. (2004). Dissection of a natural RNA silencing process in the Drosophila melanogaster germ line. Mol Cell Biol 24, 6742-6750.

Aravin, A. A., Lagos-Quintana, M., Yalcin, A., Zavolan, M., Marks, D., Snyder, B., Gaasterland, T., Meyer, J., and Tuschl, T. (2003). The small RNA profile during Drosophila melanogaster development. Dev Cell 5, 337-350.

Aravin, A. A., Naumova, N. M., Tulin, A. V., Vagin, V. V., Rozovsky, Y. M., and Gvozdev, V. A. (2001). Double-stranded RNA-mediated silencing of genomic tandem repeats and transposable elements in the D. melanogaster germline. Curr Biol 11, 10171027.

Assaad, F. F., Tucker, K. L., and Signer, E. R. (1993). Epigenetic repeat-induced gene silencing (RIGS) in Arabidopsis. Plant Mol Biol 22, 1067-1085.

Bagga, S., Bracht, J., Hunter, S., Massirer, K., Holtz, J., Eachus, R., and Pasquinelli, A. E. (2005). Regulation by let-7 and lin-4 miRNAs Results in Target mRNA Degradation. Cell 122, 553-563.

Bannwarth, S., and Gatignol, A. (2005). HIV-1 TAR RNA: the target of molecular interactions between the virus and its host. Curr HIV Res 3, 61-71.

Bartel, D. P. (2004). MicroRNAs: genomics, biogenesis, mechanism, and function. Cell 116, 281-297.

Bass, B. L. (2000). Double-stranded RNA as a template for gene silencing. Cell 101, 235-238.

Bernstein, E., Caudy, A. A., Hammond, S. M., and Hannon, G. J. (2001). Role for a bidentate ribonuclease in the initiation step of RNA interference. Nature 409, 363-366.

Billy, E., Brondani, V., Zhang, H., Muller, U., and Filipowicz, W. (2001). Specific interference with gene expression induced by long, double-stranded RNA in mouse embryonal teratocarcinoma cell lines. Proc Natl Acad Sci USA 98, 14428-14433.

Bohnsack, M. T., Czaplinski, K., and Gorlich, D. (2004). Exportin 5 is a RanGTPdependent dsRNA-binding protein that mediates nuclear export of pre-miRNAs. RNA 10, 185-191.

Cai, X., Hagedorn, C. H., and Cullen, B. R. (2004). Human microRNAs are processed from capped, polyadenylated transcripts that can also function as mRNAs. RNA.

Caldas, C., and Brenton, J. D. (2005). Sizing up miRNAs as cancer genes. Nat Med 11, 712-714. 
Cam, H. P., Sugiyama, T., Chen, E. S., Chen, X., FitzGerald, P. C., and Grewal, S. I. (2005). Comprehensive analysis of heterochromatin- and RNAi-mediated epigenetic control of the fission yeast genome. Nat Genet 37, 809-819.

Caplen, N. J., Parrish, S., Imani, F., Fire, A., and Morgan, R. A. (2001). Specific inhibition of gene expression by small double-stranded RNAs in invertebrate and vertebrate systems. Proc Natl Acad Sci USA 98, 9742-9747.

Carmell, M. A., Xuan, Z., Zhang, M. Q., and Hannon, G. J. (2002). The Argonaute family: tentacles that reach into RNAi, developmental control, stem cell maintenance, and tumorigenesis. Genes \& Dev 16, 2733-2742.

Caudy, A. A., Ketting, R. F., Hammond, S. M., Denli, A. M., Bathoorn, A. M., Tops, B. B., Silva, J. M., Myers, M. M., Hannon, G. J., and Plasterk, R. H. (2003). A micrococcal nuclease homologue in RNAi effector complexes. Nature 425, 411-414.

Caudy, A. A., Myers, M., Hannon, G. J., and Hammond, S. M. (2002). Fragile Xrelated protein and VIG associate with the RNA interference machinery. Genes \& Dev $16,2491-2496$.

Celotto, A. M., and Graveley, B. R. (2002). Exon-specific RNAi: a tool for dissecting the functional relevance of alternative splicing. RNA 8, 718-724.

Cerutti, L., Mian, N., and Bateman, A. (2000). Domains in gene silencing and cell differentiation proteins: the novel PAZ domain and redefinition of the piwi domain. Trends Biochem Sci 25, 481-482.

Chen, P. Y., Manninga, H., Slanchev, K., Chien, M., Russo, J. J., Ju, J., Sheridan, R., John, B., Marks, D. S., Gaidatzis, D., et al. (2005). The developmental miRNA profiles of zebrafish as determined by small RNA cloning. Genes \& Dev 19, 1288-1293.

Chendrimada, T. P., Gregory, R. I., Kumaraswamy, E., Norman, J., Cooch, N., Nishikura, K., and Shiekhattar, R. (2005). TRBP recruits the Dicer complex to Ago2 for microRNA processing and gene silencing. Nature 436, 740-744.

Chiu, Y. L., and Rana, T. M. (2002). RNAi in human cells. Basic structural and functional features of small interfering RNA. Mol Cell 10, 549-561.

Chiu, Y. L., and Rana, T. M. (2003). siRNA function in RNAi: A chemical modification analysis. RNA 9, 1034-1048.

Chomczynski, P., and Sacchi, N. (1987). Single-step method of RNA isolation by acid guanidinium thiocyanate-phenol-chloroform extraction. Anal Biochem 162, 156-159.

Cikaluk, D., Tahbaz, N., Hendricks, L., DiMattia G, Hansen, D., Pilgrim, D., and Hobman, T. (1999). GERp95, a membrane-associated protein that belongs to a family of proteins involved in stem cell differentiation. Mol Biol Cell 10, 3357-3722.

Cogoni, C., and Macino, G. (1997). Isolation of quelling-defective (qde) mutants impaired in posttranscriptional transgene-induced gene silencing in Neurospora crassa. Proc Natl Acad Sci USA 94, 10233-10238.

Cogoni, C., and Macino, G. (1999). Gene silencing in Neurospora crassa requires a protein homologous to RNA-dependent RNA polymerase. Nature 399, 166-169.

Cook, H. A., Koppetsch, B. S., Wu, J., and Theurkauf, W. E. (2004). The Drosophila SDE3 homolog armitage is required for oskar mRNA silencing and embryonic axis specification. Cell 116, 817-829. 
Cox, D. N., Chao, A., Baker, J., Chang, L., Qiao, D., and Lin, H. (1998). A novel class of evolutionarily conserved genes defined by piwi are essential for stem cell selfrenewal. Genes \& Dev 12, 3715-3727.

Cox, D. N., Chao, A., and Lin, H. (2000). piwi encodes a nucleoplasmic factor whose activity modulates the number and division rate of germline stem cells. Development 127, 503-514.

Czauderna, F., Fechtner, M., Dames, S., Aygun, H., Klippel, A., Pronk, G. J., Giese, K., and Kaufmann, J. (2003). Structural variations and stabilising modifications of synthetic siRNAs in mammalian cells. Nucleic Acids Res 31, 2705-2716.

Dalmay, T., Hamilton, A., Rudd, S., Angell, S., and Baulcombe, D. C. (2000). An RNA-dependent RNA polymerase gene in Arabidopsis is required for posttranscriptional gene silencing mediated by a transgene but not by a virus. Cell 101, 543-553.

Dalmay, T., Horsefield, R., Braunstein, T. H., and Baulcombe, D. C. (2001). SDE3 encodes an RNA helicase required for post-transcriptional gene silencing in Arabidopsis. EMBO J 20, 2069-2078.

Deng, W., and Lin, H. (2002). miwi, a murine homolog of piwi, encodes a cytoplasmic protein essential for spermatogenesis. Dev Cell 2, 819-830.

Denli, A. M., Tops, B. B., Plasterk, R. H., Ketting, R. F., and Hannon, G. J. (2004). Processing of primary microRNAs by the Microprocessor complex. Nature.

Deshpande, G., Calhoun, G., and Schedl, P. (2005). Drosophila argonaute-2 is required early in embryogenesis for the assembly of centric/centromeric heterochromatin, nuclear division, nuclear migration, and germ-cell formation. Genes \& Dev 19, 16801685 .

Dignam, J. D., Lebovitz, R. M., and Roeder, R. G. (1983). Accurate transcription initiation by RNA polymerase II in a soluble extract from isolated mammalian nuclei. Nucleic Acids Res 11, 1475-1489.

Djikeng, A., Shi, H., Tschudi, C., Shen, S., and Ullu, E. (2003). An siRNA ribonucleoprotein is found associated with polyribosomes in Trypanosoma brucei. RNA 9, 802-808.

Djikeng, A., Shi, H., Tschudi, C., and Ullu, E. (2001). RNA interference in Trypanosoma brucei: cloning of small interfering RNAs provides evidence for retroposon-derived 24-26-nucleotide RNAs. RNA 7, 1522-1530.

Doench, J. G., Petersen, C. P., and Sharp, P. A. (2003). siRNAs can function as miRNAs. Genes \& Dev 17, 438-442.

Doi, N., Zenno, S., Ueda, R., Ohki-Hamazaki, H., Ui-Tei, K., and Saigo, K. (2003). Short-interfering-RNA-mediated gene silencing in mammalian cells requires Dicer and eIF2C translation initiation factors. Curr Biol 13, 41-46.

Domeier, M. E., Morse, D. P., Knight, S. W., Portereiko, M., Bass, B. L., and Mango, S. E. (2000). A link between RNA interference and nonsense-mediated decay in Caenorhabditis elegans. Science 289, 1928-1931.

Dorsett, Y., and Tuschl, T. (2004). siRNAs: applications in functional genomics and potential as therapeutics. Nat Rev Drug Discov 3, 318-329.

Elbashir, S. M., Harborth, J., Lendeckel, W., Yalcin, A., Weber, K., and Tuschl, T. 
(2001a). Duplexes of 21-nucleotide RNAs mediate RNA interference in mammalian cell culture. Nature 411, 494-498.

Elbashir, S. M., Harborth, J., Weber, K., and Tuschl, T. (2002). Analysis of gene function in somatic mammalian cells using small interfering RNAs. Methods 26, 199213.

Elbashir, S. M., Lendeckel, W., and Tuschl, T. (2001b). RNA interference is mediated by 21- and 22-nucleotide RNAs. Genes \& Dev 15, 188-200.

Elbashir, S. M., Martinez, J., Patkaniowska, A., Lendeckel, W., and Tuschl, T. (2001c). Functional anatomy of siRNAs for mediating efficient RNAi in Drosophila melanogaster embryo lysate. EMBO J 20, 6877-6888.

Elmayan, T., Balzergue, S., Beon, F., Bourdon, V., Daubremet, J., Guenet, Y., Mourrain, P., Palauqui, J. C., Vernhettes, S., Vialle, T., et al. (1998). Arabidopsis mutants impaired in cosuppression. Plant Cell 10, 1747-1758.

Filipowicz, W., Konarska, M., Gross, H. J., and Shatkin, A. J. (1983). RNA 3'-terminal phosphate cyclase activity and RNA ligation in HeLa cell extract. Nucleic Acids Res $11,1405-1418$.

Filipowicz, W., and Shatkin, A. J. (1983). Origin of splice junction phosphate in tRNAs processed by HeLa cell extract. Cell 32, 547-557.

Filipowicz, W., Strugala, K., Konarska, M., and Shatkin, A. J. (1985). Cyclization of RNA 3'-terminal phosphate by cyclase from HeLa cells proceeds via formation of N(3')pp(5')A activated intermediate. Proc Natl Acad Sci USA 82, 1316-1320.

Findley, S. D., Tamanaha, M., Clegg, N. J., and Ruohola-Baker, H. (2003). Maelstrom, a Drosophila spindle-class gene, encodes a protein that colocalizes with Vasa and RDE1/AGO1 homolog, Aubergine, in nuage. Development 130, 859-871.

Fire, A., Albertson, D., Harrison, S. W., and Moerman, D. G. (1991). Production of antisense RNA leads to effective and specific inhibition of gene expression in C. elegans muscle. Development 113, 503-514.

Fire, A., Xu, S., Montgomery, M. K., Kostas, S. A., Driver, S. E., and Mello, C. C. (1998). Potent and specific genetic interference by double-stranded RNA in Caenorhabditis elegans. Nature 391, 806-811.

Forstemann, K., Tomari, Y., Du, T., Vagin, V. V., Denli, A. M., Bratu, D. P., Klattenhoff, C., Theurkauf, W. E., and Zamore, P. D. (2005). Normal microRNA Maturation and Germ-Line Stem Cell Maintenance Requires Loquacious, a DoubleStranded RNA-Binding Domain Protein. PLoS Biol 3, e236.

Freier, S. M., Burger, B. J., Alkema, D., Neilson, T., and Turner, D. H. (1983). Effects of 3' dangling end stacking on the stability of GGCC and CCGG double helixes. Biochemistry 22, 6198-6206.

Fukagawa, T., Nogami, M., Yoshikawa, M., Ikeno, M., Okazaki, T., Takami, Y., Nakayama, T., and Oshimura, M. (2004). Dicer is essential for formation of the heterochromatin structure in vertebrate cells. Nat Cell Biol 6, 784-791.

Gregory, R. I., Chendrimada, T. P., Cooch, N., and Shiekhattar, R. (2005). Human RISC Couples MicroRNA Biogenesis and Posttranscriptional Gene Silencing. Cell.

Gregory, R. I., Yan, K. P., Amuthan, G., Chendrimada, T., Doratotaj, B., Cooch, N., and Shiekhattar, R. (2004). The Microprocessor complex mediates the genesis of 
microRNAs. Nature.

Grishok, A., Pasquinelli, A. E., Conte, D., Li, N., Parrish, S., Ha, I., Baillie, D. L., Fire, A., Ruvkun, G., and Mello, C. C. (2001). Genes and mechanisms related to RNA interference regulate expression of the small temporal RNAs that control C. elegans developmental timing. Cell 106, 23-34.

Haase, A. D., Jaskiewicz, L., Zhang, H., Laine, S., Sack, R., Gatignol, A., and Filipowicz, W. (2005). TRBP, a regulator of cellular PKR and HIV-1 virus expression, interacts with Dicer and functions in RNA silencing. EMBO Rep 6, 961-967.

Haley, B., and Zamore, P. D. (2004). Kinetic analysis of the RNAi enzyme complex. Nat Struct Mol Biol 11, 599-606.

Hall, I. M., Shankaranarayana, G. D., Noma, K., Ayoub, N., Cohen, A., and Grewal, S. I. (2002). Establishment and maintenance of a heterochromatin domain. Science 297, 2232-2237.

Hamilton, A., Voinnet, O., Chappell, L., and Baulcombe, D. (2002). Two classes of short interfering RNA in RNA silencing. EMBO J 21, 4671-4679.

Hamilton, A. J., and Baulcombe, D. C. (1999). A species of small antisense RNA in posttranscriptional gene silencing in plants. Science 286, 950-952.

Hammond, S. M., Bernstein, E., Beach, D., and Hannon, G. J. (2000). An RNA-directed nuclease mediates post-transcriptional gene silencing in Drosophila cells. Nature 404, 293-296.

Hammond, S. M., Boettcher, S., Caudy, A. A., Kobayashi, R., and Hannon, G. J. (2001). Argonaute2, a link between genetic and biochemical analyses of RNAi. Science 293, 1146-1150.

Han, J., Lee, Y., Yeom, K. H., Kim, Y. K., Jin, H., and Kim, V. N. (2004). The DroshaDGCR8 complex in primary microRNA processing. Genes \& Dev 18, 3016-3027.

Harborth, J., Elbashir, S. M., Vandenburgh, K., Manninga, H., Scaringe, S. A., Weber, K., and Tuschl, T. (2003). Sequence, chemical, and structural variation of small interfering RNAs and short hairpin RNAs and the effect on mammalian gene silencing. Antisense Nucleic Acid Drug Dev 13.

Harris, A. N., and Macdonald, P. M. (2001). Aubergine encodes a Drosophila polar granule component required for pole cell formation and related to eIF2C. Development $128,2823-2832$.

Heaton, J. H., Dlakic, W. M., Dlakic, M., and Gelehrter, T. D. (2001). Identification and cDNA cloning of a novel RNA-binding protein that interacts with the cyclic nucleotideresponsive sequence in the Type- 1 plasminogen activator inhibitor mRNA. J Biol Chem 276, 3341-3347.

Ho, C. K., Wang, L. K., Lima, C. D., and Shuman, S. (2004). Structure and mechanism of RNA ligase. Structure (Camb) 12, 327-339.

Holen, T., Amarzguioui, M., Babaie, E., and Prydz, H. (2003). Similar behaviour of single-strand and double-strand siRNAs suggests they act through a common RNAi pathway. Nucleic Acids Res 31, 2401-2407.

Holen, T., Amarzguioui, M., Wiiger, M. T., Babaie, E., and Prydz, H. (2002). Positional effects of short interfering RNAs targeting the human coagulation trigger Tissue Factor. Nucleic Acids Res 30, 1757-1766. 
Humphreys, D. T., Westman, B. J., Martin, D. I., and Preiss, T. (2005). MicroRNAs control translation initiation by inhibiting eukaryotic initiation factor 4E/cap and poly(A) tail function. Proc Natl Acad Sci USA 102, 16961-16966.

Hutvagner, G., McLachlan, J., Pasquinelli, A. E., Balint, E., Tuschl, T., and Zamore, P. D. (2001). A cellular function for the RNA-interference enzyme Dicer in the maturation of the let-7 small temporal RNA. Science 293, 834-838.

Hutvagner, G., and Zamore, P. D. (2002). A microRNA in a multiple-turnover RNAi enzyme complex. Science 297, 2056-2060.

Ishizuka, A., Siomi, M. C., and Siomi, H. (2002). A Drosophila fragile X protein interacts with components of RNAi and ribosomal proteins. Genes \& Dev 16, 24972508 .

Jakymiw, A., Lian, S., Eystathioy, T., Li, S., Satoh, M., Hamel, J. C., Fritzler, M. J., and Chan, E. K. (2005). Disruption of GW bodies impairs mammalian RNA interference. Nat Cell Biol.

Jiang, F., Ye, X., Liu, X., Fincher, L., McKearin, D., and Liu, Q. (2005). Dicer-1 and R3D1-L catalyze microRNA maturation in Drosophila. Genes \& Dev 19, 1674-1679.

Jin, P., Alisch, R. S., and Warren, S. T. (2004). RNA and microRNAs in fragile X mental retardation. Nat Cell Biol 6, 1048-1053.

Kanellopoulou, C., Muljo, S. A., Kung, A. L., Ganesan, S., Drapkin, R., Jenuwein, T., Livingston, D. M., and Rajewsky, K. (2005). Dicer-deficient mouse embryonic stem cells are defective in differentiation and centromeric silencing. Genes \& Dev 19, 489501.

Kato, H., Goto, D. B., Martienssen, R. A., Urano, T., Furukawa, K., and Murakami, Y. (2005). RNA polymerase II is required for RNAi-dependent heterochromatin assembly. Science 309, 467-469.

Kennerdell, J. R., and Carthew, R. W. (1998). Use of dsRNA-mediated genetic interference to demonstrate that frizzled and frizzled 2 act in the wingless pathway. Cell 95, 1017-1026.

Kennerdell, J. R., Yamaguchi, S., and Carthew, R. W. (2002). RNAi is activated during Drosophila oocyte maturation in a manner dependent on aubergine and spindle-E. Genes \& Dev 16, 1884-1889.

Ketting, R. F., Fischer, S. E., Bernstein, E., Sijen, T., Hannon, G. J., and Plasterk, R. H. (2001). Dicer functions in RNA interference and in synthesis of small RNA involved in developmental timing in C. elegans. Genes \& Dev 15, 2654-2659.

Khvorova, A., Reynolds, A., and Jayasena, S. D. (2003). Functional siRNAs and miRNAs exhibit strand bias. Cell 115, 209-216.

Kim, J., Krichevsky, A., Grad, Y., Hayes, G. D., Kosik, K. S., Church, G. M., and Ruvkun, G. (2004). Identification of many microRNAs that copurify with polyribosomes in mammalian neurons. Proc Natl Acad Sci USA 101, 360-365.

Kim, V. N. (2005). Small RNAs: classification, biogenesis, and function. Mol Cells 19, $1-15$.

Koesters, R., Adams, V., Betts, D., Moos, R., Schmid, M., Siermann, A., Hassam, S., Weitz, S., Lichter, P., Heitz, P. U., et al. (1999). Human eukaryotic initiation factor EIF2C1 gene: cDNA sequence, genomic organization, localization to chromosomal 
bands 1p34-p35, and expression. Genomics 61, 210-218.

Krutzfeldt, J., Rajewsky, N., Braich, R., Rajeev, K. G., Tuschl, T., Manoharan, M., and Stoffel, M. (2005). Silencing of microRNAs in vivo with 'antagomirs'. Nature 438, 685689.

Kuramochi-Miyagawa, S., Kimura, T., Ijiri, T. W., Isobe, T., Asada, N., Fujita, Y., Ikawa, M., Iwai, N., Okabe, M., Deng, W., et al. (2004). Mili, a mammalian member of piwi family gene, is essential for spermatogenesis. Development 131, 839-849.

Kuramochi-Miyagawa, S., Kimura, T., Yomogida, K., Kuroiwa, A., Tadokoro, Y., Fujita, Y., Sato, M., Matsuda, Y., and Nakano, T. (2001). Two mouse piwi-related genes: miwi and mili. Mech Dev 108, 121-133.

Lagos-Quintana, M., Rauhut, R., Lendeckel, W., and Tuschl, T. (2001). Identification of novel genes coding for small expressed RNAs. Science 294, 853-858.

Landthaler, M., Yalcin, A., and Tuschl, T. (2004). The Human DiGeorge Syndrome Critical Region Gene 8 and Its D. melanogaster Homolog Are Required for miRNA Biogenesis. Curr Biol 14, 2162-2167.

Lau, N. C., Lim, L. P., Weinstein, E. G., and Bartel, D. P. (2001). An abundant class of tiny RNAs with probable regulatory roles in Caenorhabditis elegans. Science 294, 858862.

Lee, R. C., and Ambros, V. (2001). An extensive class of small RNAs in Caenorhabditis elegans. Science 294, 862-864.

Lee, R. C., Feinbaum, R. L., and Ambros, V. (1993). The C. elegans heterochronic gene lin-4 encodes small RNAs with antisense complementarity to lin-14. Cell 75, 843-854.

Lee, Y., Ahn, C., Han, J., Choi, H., Kim, J., Yim, J., Lee, J., Provost, P., Radmark, O., Kim, S., and Kim, V. N. (2003). The nuclear RNase III Drosha initiates microRNA processing. Nature 425, 415-419.

Lee, Y., Jeon, K., Lee, J. T., Kim, S., and Kim, V. N. (2002). MicroRNA maturation: stepwise processing and subcellular localization. EMBO J 21, 4663-4670.

Lee, Y., Kim, M., Han, J., Yeom, K. H., Lee, S., Baek, S. H., and Kim, V. N. (2004a). MicroRNA genes are transcribed by RNA polymerase II. EMBO J.

Lee, Y. S., Nakahara, K., Pham, J. W., Kim, K., He, Z., Sontheimer, E. J., and Carthew, R. W. (2004b). Distinct roles for Drosophila Dicer-1 and Dicer-2 in the siRNA/miRNA silencing pathways. Cell 117, 69-81.

Lewis, B. P., Burge, C. B., and Bartel, D. P. (2005). Conserved Seed Pairing, Often Flanked by Adenosines, Indicates that Thousands of Human Genes are MicroRNA Targets. Cell 120, 15-20.

Lim, L. P., Lau, N. C., Garrett-Engele, P., Grimson, A., Schelter, J. M., Castle, J., Bartel, D. P., Linsley, P. S., and Johnson, J. M. (2005). Microarray analysis shows that some microRNAs downregulate large numbers of target mRNAs. Nature.

Lim, L. P., Lau, N. C., Weinstein, E. G., Abdelhakim, A., Yekta, S., Rhoades, M. W., Burge, C. B., and Bartel, D. P. (2003). The microRNAs of Caenorhabditis elegans. Genes \& Dev 17, 991-1008.

Lin, H., and Spradling, A. C. (1997). A novel group of pumilio mutations affects the asymmetric division of germline stem cells in the Drosophila ovary. Development 124, 
2463-2476.

Lingel, A., Simon, B., Izaurralde, E., and Sattler, M. (2003). Structure and nucleic-acid binding of the Drosophila Argonaute 2 PAZ domain. Nature 426, 465-469.

Lingel, A., Simon, B., Izaurralde, E., and Sattler, M. (2004). Nucleic acid 3'-end recognition by the Argonaute2 PAZ domain. Nat Struct Mol Biol 11, 576-577.

Lipardi, C., Wei, Q., and Paterson, B. M. (2001). RNAi as random degradative PCR. siRNA Primers convert mRNA into dsRNAs that are degraded to generate new siRNAs. Cell 107, 297-307.

Liu, J., Carmell, M. A., Rivas, F. V., Marsden, C. G., Thomson, J. M., Song, J. J., Hammond, S. M., Joshua-Tor, L., and Hannon, G. J. (2004). Argonaute2 Is the Catalytic Engine of Mammalian RNAi. Science.

Liu, J., Rivas, F. V., Wohlschlegel, J., Yates, J. R., Parker, R., and Hannon, G. J. (2005a). A role for the P-body component GW182 in microRNA function. Nat Cell Biol.

Liu, J., Valencia-Sanchez, M. A., Hannon, G. J., and Parker, R. (2005b). MicroRNAdependent localization of targeted mRNAs to mammalian P-bodies. Nat Cell Biol 7, 719-723.

Liu, Q., Rand, T. A., Kalidas, S., Du, F., Kim, H. E., Smith, D. P., and Wang, X. (2003). R2D2, a bridge between the initiation and effector steps of the Drosophila RNAi pathway. Science 301, 1921-1925.

Llave, C., Kasschau, K. D., Rector, M. A., and Carrington, J. C. (2002a). Endogenous and silencing-associated small RNAs in plants. Plant Cell 14, 1605-1619.

Llave, C., Xie, Z., Kasschau, K. D., and Carrington, J. C. (2002b). Cleavage of Scarecrow-like mRNA targets directed by a class of Arabidopsis miRNA. Science 297, 2053-2056.

Lohmann, J. U., Endl, I., and Bosch, T. C. (1999). Silencing of Developmental Genes in Hydra. Dev Biol 214, 211-214.

Lu, J., Qian, J., Chen, F., Tang, X., Li, C., and Cardoso, W. V. (2005). Differential expression of components of the microRNA machinery during mouse organogenesis. Biochem Biophys Res Commun 334, 319-323.

Lund, E., Guttinger, S., Calado, A., Dahlberg, J. E., and Kutay, U. (2004). Nuclear export of microRNA precursors. Science 303, 95-98.

Ma, J. B., Ye, K., and Patel, D. J. (2004). Structural basis for overhang-specific small interfering RNA recognition by the PAZ domain. Nature 429, 318-322.

Ma, J. B., Yuan, Y. R., Meister, G., Pei, Y., Tuschl, T., and Patel, D. J. (2005). Structural basis for 5'-end-specific recognition of guide RNA by the A. fulgidus Piwi protein. Nature 434, 666-670.

Makeyev, E. V., and Bamford, D. H. (2002). Cellular RNA-dependent RNA polymerase involved in posttranscriptional gene silencing has two distinct activity modes. Mol Cell 10, 1417-1427.

Malik, S., and Roeder, R. G. (2003). Isolation and functional characterization of the TRAP/mediator complex. Methods Enzymol 364, 257-284.

Martens, H., Novotny, J., Oberstrass, J., Steck, T. L., Postlethwait, P., and Nellen, W. 
(2002). RNAi in Dictyostelium: the role of RNA-directed RNA polymerases and double-stranded RNase. Mol Biol Cell 13, 445-453.

Martienssen, R. A., Zaratiegui, M., and Goto, D. B. (2005). RNA interference and heterochromatin in the fission yeast Schizosaccharomyces pombe. Trends Genet 21, 450-456.

Martinez, J., Patkaniowska, A., Urlaub, H., Luhrmann, R., and Tuschl, T. (2002). Single-stranded antisense siRNAs guide target RNA cleavage in RNAi. Cell 110, 563574.

Martinez, J., and Tuschl, T. (2004). RISC is a 5 ' phosphomonoester-producing RNA endonuclease. Genes \& Dev 18.

Matranga, C., Tomari, Y., Shin, C., Bartel, D. P., and Zamore, P. D. (2005). PassengerStrand Cleavage Facilitates Assembly of siRNA into Ago2-Containing RNAi Enzyme Complexes. Cell.

Matzke, A. J., Neuhuber, F., Park, Y. D., Ambros, P. F., and Matzke, M. A. (1994). Homology-dependent gene silencing in transgenic plants: epistatic silencing loci contain multiple copies of methylated transgenes. Mol Gen Genet 244, 219-229.

Meister, G., Landthaler, M., Patkaniowska, A., Dorsett, Y., Teng, G., and Tuschl, T. (2004). Human Argonaute 2 mediates RNA cleavage targeted by miRNAs and siRNAs. Mol Cell 15, 185-197.

Meister, G., Landthaler, M., Peters, L., Chen, P. Y., Urlaub, H., Luhrmann, R., and Tuschl, T. (2005). Identification of Novel Argonaute-Associated Proteins. Curr Biol.

Mette, M. F., van der Winden, J., Matzke, M., and Matzke, A. J. (2002). Short RNAs can identify new candidate transposable element families in Arabidopsis. Plant Physiol 130, 6-9.

Mittal, V. (2004). Improving the efficiency of RNA interference in mammals. Nat Rev Genet 5, 355-365.

Mochizuki, K., Fine, N. A., Fujisawa, T., and Gorovsky, M. A. (2002). Analysis of a piwi-related gene implicates small RNAs in genome rearrangement in tetrahymena. Cell 110, 689-699.

Montgomery, M. K., Xu, S., and Fire, A. (1998). RNA as a target of double-stranded RNA-mediated genetic interference in Caenorhabditis elegans. Proc Natl Acad Sci USA 95, 15502-15507.

Mooslehner, K., Muller, U., Karls, U., Hamann, L., and Harbers, K. (1991). Structure and expression of a gene encoding a putative GTP-binding protein identified by provirus integration in a transgenic mouse strain. Mol Cell Biol 11, 886-893.

Motamedi, M. R., Verdel, A., Colmenares, S. U., Gerber, S. A., Gygi, S. P., and Moazed, D. (2004). Two RNAi complexes, RITS and RDRC, physically interact and localize to noncoding centromeric RNAs. Cell 119, 789-802.

Mourelatos, Z., Dostie, J., Paushkin, S., Sharma, A., Charroux, B., Abel, L., Rappsilber, J., Mann, M., and Dreyfuss, G. (2002). miRNPs: a novel class of ribonucleoproteins containing numerous microRNAs. Genes \& Dev 16, 720-728.

Mourrain, P., Béclin, C., Elmayan, T., Feuerbach, F., Godon, C., Morel, J. B., Jouette, D., Lacombe, A. M., Nikic, S., Picault, N., et al. (2000). Arabidopsis SGS2 and SGS3 genes are required for posttranscriptional gene silencing and natural virus resistance. 
Cell 101, 533-542.

Nakano, H., Amemiya, S., Shiokawa, K., and Taira, M. (2000). RNA interference for the organizer-specific gene Xlim-1 in Xenopus embryos. Biochem Biophys Res Commun 274, 434-439.

Napoli, C., Lemieux, C., and Jorgensen, R. (1990). Introduction of a chimeric chalcone synthase gene into Petunia results in reversible co-suppression of homologous genes in trans. Plant Cell 2, 279-289.

Nelson, P. T., Hatzigeorgiou, A. G., and Mourelatos, Z. (2004). miRNP:mRNA association in polyribosomes in a human neuronal cell line. RNA 10, 387-394.

Ngo, H., Tschudi, C., Gull, K., and Ullu, E. (1998). Double-stranded RNA induces mRNA degradation in Trypanosoma brucei. Proc Natl Acad Sci USA 95, 14687-14692.

Nicholson, A. W. (1999). Function, mechanism and regulation of bacterial ribonucleases. FEMS Microbiol Rev 23, 371-390.

Noma, K., Sugiyama, T., Cam, H., Verdel, A., Zofall, M., Jia, S., Moazed, D., and Grewal, S. I. (2004). RITS acts in cis to promote RNA interference-mediated transcriptional and post-transcriptional silencing. Nat Genet 36, 1174-1180.

Nykänen, A., Haley, B., and Zamore, P. D. (2001). ATP requirements and small interfering RNA structure in the RNA interference pathway. Cell 107, 309-321.

Okamura, K., Ishizuka, A., Siomi, H., and Siomi, M. C. (2004). Distinct roles for Argonaute proteins in small RNA-directed RNA cleavage pathways. Genes \& Dev 18, $1655-1666$.

Olsen, P. H., and Ambros, V. (1999). The lin-4 regulatory RNA controls developmental timing in Caenorhabditis elegans by blocking LIN-14 protein synthesis after the initiation of translation. Dev Biol 216, 671-680.

Orban, T. I., and Izaurralde, E. (2005). Decay of mRNAs targeted by RISC requires XRN1, the Ski complex, and the exosome. RNA 11, 459-469.

Pal-Bhadra, M., Bhadra, U., and Birchler, J. A. (2002). RNAi related mechanism affect both transcriptional and posttranscriptional transgene silencing in Drosophila. Mol Cell 9, 315-327.

Pal-Bhadra, M., Leibovitch, B. A., Gandhi, S. G., Rao, M., Bhadra, U., Birchler, J. A., and Elgin, S. C. (2004). Heterochromatic silencing and HP1 localization in Drosophila are dependent on the RNAi machinery. Science 303, 669-672.

Pandit, N. N., and Russo, V. E. (1992). Reversible inactivation of a foreign gene, hph, during the asexual cycle in Neurospora crassa transformants. Mol Gen Genet 234, 412 422 .

Parker, J. S., Roe, S. M., and Barford, D. (2004). Crystal structure of a PIWI protein suggests mechanisms for siRNA recognition and slicer activity. EMBO J 23, 47274737.

Parker, J. S., Roe, S. M., and Barford, D. (2005). Structural insights into mRNA recognition from a PIWI domain-siRNA guide complex. Nature 434, 663-666.

Parrish, S., Fleenor, J., Xu, S., Mello, C., and Fire, A. (2000). Functional anatomy of a dsRNA trigger: Differential requirement for the two trigger strands in RNA Interference. Mol Cell 6, 1077-1087. 
Parvinen, M. (2005). The chromatoid body in spermatogenesis. Int J Androl 28, 189201.

Pasquinelli, A. E., Reinhart, B. J., Slack, F., Martindale, M. Q., Kuroda, M. I., Maller, B., Hayward, D. C., Ball, E. D., Degnan, B., Müller, P., et al. (2000). Conservation of the sequence of let-7 heterochronic regulatory RNA. Nature 408, 86-89.

Perkins, K. K., Furneaux, H., and Hurwitz, J. (1985). Isolation and characterization of an RNA ligase from HeLa cells. Proc Natl Acad Sci USA 82, 684-688.

Pfeffer, S., Lagos-Quintana, M., and Tuschl, T. (2003). Cloning of small RNA molecules. In Current Protocols in Molecular Biology, F. M. Ausubel, R. Brent, R. E. Kingston, D. D. Moore, J. G. Seidmann, J. A. Smith, and K. Struhl, eds. (New York, John Wiley and Sons), pp. 26.24.21-26.24.16.

Pham, J. W., Pellino, J. L., Lee, Y. S., Carthew, R. W., and Sontheimer, E. J. (2004). A Dicer-2-dependent 80s complex cleaves targeted mRNAs during RNAi in Drosophila. Cell 117, 83-94.

Pillai, R. S., Artus, C. G., and Filipowicz, W. (2004). Tethering of human Ago proteins to mRNA mimics the miRNA-mediated repression of protein synthesis. RNA.

Pillai, R. S., Bhattacharyya, S. N., Artus, C. G., Zoller, T., Cougot, N., Basyuk, E., Bertrand, E., and Filipowicz, W. (2005). Inhibition of Translational Initiation by let-7 MicroRNA in Human Cells. Science.

Preall, J. B., and Sontheimer, E. J. (2005). RNAi: RISC gets loaded. Cell 123, 543-545.

Qiao, D., Zeeman, A. M., Deng, W., Looijenga, L. H., and Lin, H. (2002). Molecular characterization of hiwi, a human member of the piwi gene family whose overexpression is correlated to seminomas. Oncogene 21, 3988-3999.

Rand, T. A., Petersen, S., Du, F., and Wang, X. (2005). Argonaute2 Cleaves the AntiGuide Strand of siRNA during RISC Activation. Cell.

Randall, G., Grakoui, A., and Rice, C. M. (2003). Clearance of replicating hepatitis C virus replicon RNAs in cell culture by small interfering RNAs. Proc Natl Acad Sci USA $100,235-240$.

Rapozzi, V., and Xodo, L. E. (2004). Efficient silencing of bcr/abl oncogene by singleand double-stranded siRNAs targeted against b2a2 transcripts. Biochemistry 43, 1613416141.

Reinhart, B. J., and Bartel, D. P. (2002). Small RNAs correspond to centromere heterochromatic repeats. Science 297, 1831.

Reinhart, B. J., Slack, F. J., Basson, M., Pasquinelli, A. E., Bettinger, J. C., Rougvie, A. E., Horvitz, H. R., and Ruvkun, G. (2000). The 21-nucleotide let-7 RNA regulates developmental timing in Caenorhabditis elegans. Nature 403, 901-906.

Rivas, F. V., Tolia, N. H., Song, J. J., Aragon, J. P., Liu, J., Hannon, G. J., and JoshuaTor, L. (2005). Purified Argonaute 2 and an siRNA form recombinant human RISC. Nat Struct Mol Biol 12, 340-349.

Robertson, H. D. (1982). Escherichia coli ribonuclease III cleavage sites. Cell 30, 669672.

Robertson, H. D., Webster, R. E., and Zinder, N. D. (1968). Purification and properties of ribonuclease III from Escherichia coli. J Biol Chem 243, 82-91. 
Rocak, S., and Linder, P. (2004). DEAD-box proteins: the driving forces behind RNA metabolism. Nat Rev Mol Cell Biol 5, 232-241.

Rodriguez, A. J., Seipel, S. A., Hamill, D. R., Romancino, D. P., M, D. I. C., Suprenant, K. A., and Bonder, E. M. (2005). Seawi--a sea urchin piwi/argonaute family member is a component of MT-RNP complexes. RNA 11, 646-656.

Roignant, J. Y., Carre, C., Mugat, B., Szymczak, D., Lepesant, J. A., and Antoniewski, C. (2003). Absence of transitive and systemic pathways allows cell-specific and isoform-specific RNAi in Drosophila. RNA 9, 299-308.

Romano, N., and Macino, G. (1992). Quelling: transient inactivation of gene expression in Neurospora crassa by transformation with homologous sequences. Mol Microbiol 6, 3343-3353.

Rousseaux, S., Caron, C., Govin, J., Lestrat, C., Faure, A. K., and Khochbin, S. (2005). Establishment of male-specific epigenetic information. Gene 345, 139-153.

Roy, A. L., Chakrabarti, D., Datta, B., Hileman, R. E., and Gupta, N. K. (1988). Natural mRNA is required for directing Met-tRNA(f) binding to 40S ribosomal subunits in animal cells: involvement of Co-eIF-2A in natural mRNA-directed initiation complex formation. Biochemistry 27, 8203-8209.

Saito, K., Ishizuka, A., Siomi, H., and Siomi, M. C. (2005). Processing of premicroRNAs by the Dicer-1-Loquacious complex in Drosophila cells. PLoS Biol 3, e235.

Sambrook, J., and Russell, D. W. (2001). Molecular Cloning, 3rd edn (Cold Spring Harbor, NY, CSHL Press).

Sánchez-Alvarado, A., and Newmark, P. A. (1999). Double-stranded RNA specifically disrupts gene expression during planarian regeneration. Proc Natl Acad Sci USA 96, 5049-5054.

Sarot, E., Payen-Groschene, G., Bucheton, A., and Pelisson, A. (2004). Evidence for a piwi-dependent RNA silencing of the gypsy endogenous retrovirus by the Drosophila melanogaster flamenco gene. Genetics 166, 1313-1321.

Sasaki, T., Shiohama, A., Minoshima, S., and Shimizu, N. (2003). Identification of eight members of the Argonaute family in the human genome. Genomics 82, 323-330.

Scadden, A. D. (2005). The RISC subunit Tudor-SN binds to hyper-edited doublestranded RNA and promotes its cleavage. Nat Struct Mol Biol 12, 489-496.

Schmidt, A., Palumbo, G., Bozzetti, M. P., Tritto, P., Pimpinelli, S., and Schafer, U. (1999). Genetic and molecular characterization of sting, a gene involved in crystal formation and meiotic drive in the male germ line of Drosophila melanogaster. Genetics $151,749-760$.

Schwarz, D. S., Hutvagner, G., Du, T., Xu, Z., Aronin, N., and Zamore, P. D. (2003). Asymmetry in the assembly of the RNAi enzyme complex. Cell 115, 199-208.

Schwarz, D. S., Hutvagner, G., Haley, B., and Zamore, P. D. (2002). Evidence that siRNAs function as guides, not primers, in the Drosophila and human RNAi pathways. Mol Cell 10, 537-548.

Schwarz, D. S., Tomari, Y., and Zamore, P. D. (2004). The RNA-induced silencing complex Is a $\mathrm{Mg}(2+)$-dependent endonuclease. Curr Biol 14, 787-791. 
Seipel, K., Yanze, N., and Schmid, V. (2004). The germ line and somatic stem cell gene Cniwi in the jellyfish Podocoryne carnea. Int J Dev Biol 48, 1-7.

Sen, G. L., and Blau, H. M. (2005). Argonaute 2/RISC resides in sites of mammalian mRNA decay known as cytoplasmic bodies. Nat Cell Biol 7, 633-636.

Sharma, A. K., Nelson, M. C., Brandt, J. E., Wessman, M., Mahmud, N., Weller, K. P., and Hoffman, R. (2001). Human CD34(+) stem cells express the hiwi gene, a human homologue of the Drosophila gene piwi. Blood 97, 426-434.

Sheth, U., and Parker, R. (2003). Decapping and decay of messenger RNA occur in cytoplasmic processing bodies. Science 300, 805-808.

Shuman, S., and Hurwitz, J. (1979). 5'-Hydroxyl polyribonucleotide kinase from HeLa cell nuclei. Purification and properties. J Biol Chem 254, 10396-10404.

Sigova, A., Rhind, N., and Zamore, P. D. (2004). A single Argonaute protein mediates both transcriptional and posttranscriptional silencing in Schizosaccharomyces pombe. Genes \& Dev 18, 2359-2367.

Sijen, T., Fleenor, J., Simmer, F., Thijssen, K. L., Parrish, S., Timmons, L., Plasterk, R. H., and Fire, A. (2001). On the role of RNA amplification in dsRNA-triggered gene silencing. Cell 107, 465-476.

Sijen, T., and Plasterk, R. H. (2003). Transposon silencing in the Caenorhabditis elegans germ line by natural RNAi. Nature 426, 310-314.

Siolas, D., Lerner, C., Burchard, J., Ge, W., Linsley, P. S., Paddison, P. J., Hannon, G. J., and Cleary, M. A. (2005). Synthetic shRNAs as potent RNAi triggers. Nat Biotech $23,227-231$.

Smardon, A., Spoerke, J., Stacey, S., Klein, M., Mackin, N., and Maine, E. (2000). EGO-1 is related to RNA-directed RNA polymerase and functions in germ-line development and RNA interference in C. elegans. Curr Biol 10, 169-178.

Song, J. J., Liu, J., Tolia, N. H., Schneiderman, J., Smith, S. K., Martienssen, R. A., Hannon, G. J., and Joshua-Tor, L. (2003). The crystal structure of the Argonaute2 PAZ domain reveals an RNA binding motif in RNAi effector complexes. Nat Struct Biol 10, 1026-1032.

Song, J. J., Smith, S. K., Hannon, G. J., and Joshua-Tor, L. (2004). Crystal Structure of Argonaute and Its Implications for RISC Slicer Activity. Science.

Stapleton, W., Das, S., and McKee, B. D. (2001). A role of the Drosophila homeless gene in repression of Stellate in male meiosis. Chromosoma 110, 228-240.

Stark, G. R., Kerr, I. M., Williams, B. R., Silverman, R. H., and Schreiber, R. D. (1998). How cells respond to interferons. Annu Rev Biochem 67, 227-264.

Tabara, H., Sarkissian, M., Kelly, W. G., Fleenor, J., Grishok, A., Timmons, L., Fire, A., and Mello, C. C. (1999). The rde-1 gene, RNA interference, and transposon silencing in C. elegans. Cell 99, 123-132.

Tabara, H., Yigit, E., Siomi, H., and Mello, C. C. (2002). The dsRNA binding protein RDE-4 interacts with RDE-1, DCR-1, and a DExH-box helicase to direct RNAi in C. elegans. Cell 109, 861-871.

Tahbaz, N., Kolb, F. A., Zhang, H., Jaronczyk, K., Filipowicz, W., and Hobman, T. C. (2004). Characterization of the interactions between mammalian PAZ PIWI domain 
proteins and Dicer. EMBO Rep 5, 189-194.

Teixeira, D., Sheth, U., Valencia-Sanchez, M. A., Brengues, M., and Parker, R. (2005). Processing bodies require RNA for assembly and contain nontranslating mRNAs. RNA $11,371-382$.

Tijsterman, M., Ketting, R. F., Okihara, K. L., and Plasterk, R. H. (2002a). RNA helicase MUT-14-dependent silencing triggered in C. elegans by short antisense RNAs. Science 295, 694-697.

Tijsterman, M., Okihara, K. L., Thijssen, K., and Plasterk, R. H. (2002b). PPW-1, a PAZ/PIWI protein required for efficient germline RNAi, is defective in a natural isolate of C. elegans. Curr Biol 12, 1535-1540.

Tomari, Y., Du, T., Haley, B., Schwarz, D. S., Bennett, R., Cook, H. A., Koppetsch, B. S., Theurkauf, W. E., and Zamore, P. D. (2004a). RISC assembly defects in the Drosophila RNAi mutant armitage. Cell 116, 831-841.

Tomari, Y., Matranga, C., Haley, B., Martinez, N., and Zamore, P. D. (2004b). A protein sensor for siRNA asymmetry. Science 306, 1377-1380.

Tomari, Y., and Zamore, P. D. (2005a). MicroRNA Biogenesis: Drosha Can't Cut It without a Partner. Curr Biol 15, R61-64.

Tomari, Y., and Zamore, P. D. (2005b). Perspective: machines for RNAi. Genes \& Dev $19,517-529$.

Tuschl, T. (2002). Expanding small RNA interference. Nat Biotech 20, 446-448.

Tuschl, T., Zamore, P. D., Lehmann, R., Bartel, D. P., and Sharp, P. A. (1999). Targeted mRNA degradation by double-stranded RNA in vitro. Genes \& Dev 13, 31913197.

Ullu, E., Tschudi, C., and Chakraborty, T. (2004). RNA interference in protozoan parasites. Cell Microbiol 6, 509-519.

van der Krol, A. R., Mur, L. A., Beld, M., Mol, J. N., and Stuitje, A. R. (1990). Flavonoid genes in petunia: addition of a limited number of gene copies may lead to a suppression of gene expression. Plant Cell 2, 291-299.

Verdel, A., Jia, S., Gerber, S., Sugiyama, T., Gygi, S., Grewal, S. I., and Moazed, D. (2004). RNAi-mediated targeting of heterochromatin by the RITS complex. Science $303,672-676$.

Verdel, A., and Moazed, D. (2005). RNAi-directed assembly of heterochromatin in fission yeast. FEBS Lett 579, 5872-5878.

Volpe, T. A., Kidner, C., Hall, I. M., Teng, G., Grewal, S. I., and Martienssen, R. A. (2002). Regulation of heterochromatic silencing and histone H3 lysine-9 methylation by RNAi. Science 297, 1833-1837.

Waterhouse, P. M., Graham, M. W., and Wang, M. B. (1998). Virus resistance and gene silencing in plants can be induced by simultaneous expression of sense and antisense RNA. Proc Natl Acad Sci USA 95, 13959-13964.

Wianny, F., and Zernicka-Goetz, M. (2000). Specific interference with gene function by double-stranded RNA in early mouse development. Nat Cell Biol 2, 70-75.

Wienholds, E., and Plasterk, R. H. (2005). MicroRNA function in animal development. FEBS Lett 579, 5911-5922. 
Wightman, B., Ha, I., and Ruvkun, G. (1993). Posttranscriptional regulation of the heterochronic gene lin-14 by lin-4 mediates temporal pattern formation in C. elegans. Cell 75, 855-862.

Wilczynska, A., Aigueperse, C., Kress, M., Dautry, F., and Weil, D. (2005). The translational regulator CPEB1 provides a link between dcp1 bodies and stress granules. J Cell Sci 118, 981-992.

Wilson, J. E., Connell, J. E., and Macdonald, P. M. (1996). aubergine enhances oskar translation in the Drosophila ovary. Development 122, 1631-1639.

Xie, Z., Johansen, L. K., Gustafson, A. M., Kasschau, K. D., Lellis, A. D., Zilberman, D., Jacobsen, S. E., and Carrington, J. C. (2004). Genetic and functional diversification of small RNA pathways in plants. PLoS Biol 2, E104.

Xu, Y., Linde, A., Larsson, O., Thormeyer, D., Elmen, J., Wahlestedt, C., and Liang, Z. (2004). Functional comparison of single- and double-stranded siRNAs in mammalian cells. Biochem Biophys Res Commun 316, 680-687.

Yan, K. S., Yan, S., Farooq, A., Han, A., Zeng, L., and Zhou, M. M. (2003). Structure and conserved RNA binding of the PAZ domain. Nature 426, 468-474.

Yang, D., Lu, H., and Erickson, J. W. (2000). Evidence that processed small dsRNAs may mediate sequence-specific mRNA degradation during RNAi in Drosophila embryos. Curr Biol 10, 1191-1200.

Yang, S., Tutton, S., Pierce, E., and Yoon, K. (2001). Specific double-stranded RNA interference in undifferentiated mouse embryonic stem cells. Mol Cell Biol 21, 78077816.

Yang, W., and Steitz, T. A. (1995). Recombining the structures of HIV integrase, RuvC and RNase H. Structure 3, 131-134.

Yekta, S., Shih, I. H., and Bartel, D. P. (2004). MicroRNA-directed cleavage of HOXB8 mRNA. Science 304, 594-596.

Yi, R., Qin, Y., Macara, I. G., and Cullen, B. R. (2003). Exportin-5 mediates the nuclear export of pre-microRNAs and short hairpin RNAs. Genes \& Dev 17, 3011-3016.

Yuan, Y. R., Pei, Y., Ma, J. B., Kuryavyi, V., Zhadina, M., Meister, G., Chen, H. Y., Dauter, Z., Tuschl, T., and Patel, D. J. (2005). Crystal Structure of A. aeolicus Argonaute, a Site-Specific DNA-Guided Endoribonuclease, Provides Insights into RISC-Mediated mRNA Cleavage. Mol Cell 19, 405-419.

Zamore, P. D., Tuschl, T., Sharp, P. A., and Bartel, D. P. (2000). RNAi: Doublestranded RNA directs the ATP-dependent cleavage of mRNA at 21 to 23 nucleotide intervals. Cell 101, 25-33.

Zeng, Y., Yi, R., and Cullen, B. R. (2003). MicroRNAs and small interfering RNAs can inhibit mRNA expression by similar mechanisms. Proc Natl Acad Sci USA 100, 97799784.

Zhong, J., Peters, A. H., Lee, K., and Braun, R. E. (1999). A double-stranded RNA binding protein required for activation of repressed messages in mammalian germ cells. Nat Genet 22, 171-174.

Zou, C., Zhang, Z., Wu, S., and Osterman, J. C. (1998). Molecular cloning and characterization of a rabbit eIF2C protein. Gene 211, 187-194. 


\section{CURRICULUM VITAE}

\section{Agnieszka Patkaniowska}

Date and Place of Birth:

Contact Address:

E-mail:

\section{Education}

$1991-1995$

$1995-2000$

June 2000

\author{
August 9, 1976 in Kraków, Poland \\ Laboratory of RNA Molecular Biology \\ The Rockefeller University \\ 1230 York Ave, Box 186 \\ New York, NY 10021 \\ patkana@gmail.com
}

Undergraduate studies at the Jan III Sobieski College, Kraków, Poland

Graduate studies in Biotechnology at the Institute of Molecular Biology, Jagiellonian University, Kraków, Poland

Master of Science in Biotechnology, graduated with distinction Thesis entitled Culture and differentiation of autologous human adipocytes for the plastic surgery purpose

Group of Prof. Włodzimierz Korohoda

Dept. of Cell Biology, Jagiellonian University, Kraków, Poland

Sep 2000 - Aug 2001 International Program in Molecular Biology, Göttingen, Germany Georg-August-Universität and MPI für biophysikalische Chemie

since Oct 2001

PhD studies at the University of Göttingen, Germany

Group of Dr. Thomas Tuschl

MPI for Biophysical Chemistry, Göttingen, Germany (until Dec 2002)

The Rockefeller University, New York, NY, USA (since Jan 2003)

\section{Scholarships}

$1997-2000$

Feb - Jul 1998
Jagiellonian University Scholarship

Tempus Mobility Grant for the international research exchange Project entitled Nucleic acids (genes and oligonucleotides) transfer to mammalian cell by polylysine derivatives - study of uptake and biological activity

Group of Dr. Patrick Midoux

Center for Molecular Biophysics, CNRS, Orleans, France 


\section{PUBLICATIONS AND PRESENTATIONS}

\section{Publications}

\section{Papers}

Elbashir SM, Martinez J, Patkaniowska A, Lendeckel W, Tuschl T.

Functional anatomy of siRNAs for mediating efficient RNAi in Drosophila melanogaster embryo lysate.

EMBO J. 2001 Dec 3;20(23):6877-88.

Martinez J, Patkaniowska A, Urlaub H, Lührmann R, Tuschl T.

Single-stranded antisense siRNAs guide target RNA cleavage in RNAi.

Cell. 2002 Sep 6;110(5):563-74.

Meister G, Landthaler M, Patkaniowska A, Dorsett Y, Teng G, Tuschl T.

Human Argonaute 2 mediates RNA cleavage targeted by miRNAs and siRNAs.

Mol Cell. 2004 Jul 23;15(2):185-97.

\section{Book chapter}

Patkaniowska A, Tuschl T.

Gene silencing by synthetic siRNA duplexes in mammalian culture.

RNA Interference (RNAi): The Nuts \& Bolts of siRNA Technology by David Engelke.

DNA Press. 2003.

\section{Poster presentations}

Patkaniowska A, Martinez, J, Rauhut R, Tuschl T.

The family of Argonaute proteins in HeLa cells.

Cytoplasmic fate of RNA, German-Israeli Minerva School, Berlin, Apr 19-21, 2002.

Martinez J, Patkaniowska A, Elbashir S, Harborth J, Manninga H, Urlaub H,

Lührmann R, Tuschl T.

Single-stranded antisense siRNAs guide target RNA cleavage in RNAi.

Congress of the FEBS, Istanbul, Oct 20-25, 2002.

Meister G, Patkaniowska A, Tuschl T.

Functional characterization of the human Argonaute protein family.

siRNAs and miRNAs, Keystone Symposia, Keystone, Apr 14-19, 2004.

Patkaniowska A, Landthaler M, Meister G, Teng G, Tuschl T.

Characterization of the human Argonaute (PPD) protein family.

Congress of the FEBS, Warsaw, Jun 26 - Jul 1, 2004. 